FaCuldade de Filosofia, Letras e CiênCias Humanas dA Universidade de SÃo PaUlo

DEPARTAMENTO DE LinguísticA

\title{
O Tempo na Interpretação Musical: Uma Escuta Tensiva
}

[Versão Corrigida segundo Resolução CoPGr 6018, de 13 de outubro de 2011, o exemplar original se encontra disponível no CAPH da FFLCH.]

Marina Maluli César

São Paulo

2012 


\section{Marina Maluli César}

E-mail:marina.maluli@usp.br

\section{O Tempo na Interpretação Musical: Uma Escuta Tensiva}

[Versão Corrigida segundo Resolução CoPGr 6018, de 13 de outubro de 2011, o exemplar original se encontra disponível no CAPH da FFLCH.]

Dissertação apresentada ao Departamento de Linguística da Faculdade de Filosofia, Letras e Ciências Humanas da Universidade de São Paulo, para a obtenção de Título de Mestre, na Área de Semiótica e Linguística Geral.

Orientador: Prof. Dr. Luiz Augusto de Moraes Tatit.

São Paulo 
Nome: CÉSAR, Marina Maluli.

Título: O tempo na interpretação musical: Uma escuta tensiva.

[Versão Corrigida segundo Resolução CoPGr 6018, de 13 de outubro de 2011, o exemplar original se encontra disponível no CAPH da FFLCH.]

Dissertação apresentada ao Departamento de Linguística da Faculdade de Filosofia, Letras e Ciências Humanas da Universidade de São Paulo, para a obtenção de Título de Mestre, na Área de Semiótica e Linguística Geral.

Orientador: Prof. Dr. Luiz Augusto de Moraes Tatit.

Aprovado em: $29 \backslash 01 \backslash 2013$.

De acordo:

Prof. Dr. Luiz Augusto de Moraes Tatit 


\section{Dedicatória}

Dedico esta dissertação à todos os estudantes de escola pública que ainda lutam para continuar seus estudos. 


\section{Agradecimentos}

Ao meu orientador, prof. Luiz Tatit, destinador transcendente, pela confiança em iniciar este trabalho, pela orientação e paciência.

Ao professor Leland McCleary, por me mostrar novos caminhos e leituras possíveis para os gestos e pensamentos.

Aos professores Evani Viotti e Diana Luz Pessoa de Barros, por me incitarem ao debate saudável e mostrarem as muitas formas de ver e ouvir um mesmo objeto.

À professora Elizabeth Harkot-de-La-Taille, pela participação em minha qualificação e defesa, e pelo convite à um ouvir sensível.

Aos professores Ivã Lopes e Waldir Beividas, pela força e auxílio em momentos fundamentais de meu percurso.

Aos pesquisadores Maria Giulia Dondero e Sémir Badir, por terem me acolhido e orientado durante meu estágio de pesquisa na Universidade de Liége.

À Marisa Lacorte, mestra dos sons.

À José Roberto do Carmo, pelas trocas semio-musicais.

À Alessandra Lima, Beatriz Blanco e Lucas Shimoda, onde tudo começou... Ao Ricardo Monteiro, pelas sugestões em minha qualificação, e pela participação na banca de defesa.

À Zeineb Allani e Imyra Santana, pelo auxílio com a transcrição e revisão da entrevista com Greimas.

À Carolina Lemos, pela troca de ideias e empréstimo de materiais e pelo acolhimento em minha chegada durante o inverno.

Aos meus amigos e colegas do curso de linguística, pela cumplicidade, ajuda 
e amizade.

À amiga Ilca Suzana, pelas conversas, leituras, revisão atenta do texto e tardes de café na padaria.

Ao Eduardo, pelo carinho e pelos momentos sensíveis que precederam, sustentaram, e com frequência estiveram além de todos os meus esforços inteligíveis.

À minha mãe.

À Érica, ao Robson e ao Benhur, pela paciência e esclarecimentos.

À Faculdade de Filosofia, Letras e Ciências Humanas da Universidade de São Paulo, e em particular ao Departamento de Linguística, por me possibilitar desenvolver minha Pós-Graduação em um ambiente extremamente enriquecedor.

Ao CNPq e ao Santander Universidades, pelo auxílio financeiro concedido durante meu mestrado e estágio no exterior, respectivamente, sem os quais esta pesquisa não seria possível.

À todos, eu agradeço. 
E o tempo é a medida do afeto.

Luiz Tatit 


\section{Resumo}

\section{CÉSAR, M. M. O tempo na interpretação musical: Uma escuta ten-}

siva. 2012. 117p. Dissertação - Faculdade de Filosofia, Letras e Ciências Humanas da Universidade de São Paulo, São Paulo, 2012.

Este trabalho tem como fundamentação teórica a semiótica de linha francesa e seus recentes desenvolvimentos tensivos. Tomamos como objeto de nosso estudo as variações de ritmo e andamento presentes em um texto sonoro, pela abordagem do plano de expressão musical. O objetivo deste trabalho consiste em compreender como tais possibilidades discursivas se articulam durante a realização da obra por um intérprete, a partir das indicações presentes na partitura. Após considerações iniciais sobre o texto e o intertexto musical, cuja finalidade é determinarmos o modo como estas potencialidades são manifestadas, consideramos o tempo em diferentes níveis segundo Gérard Grisey (1987, 2004, 2008) e Messiaen (1996, 1995, 1994). Em um segundo momento, buscamos articular os diferentes tipos de escuta segundo Schaeffer (1966) e Greimas (2008) ao considerar o ouvir como um fazer, o qual requer a aquisição de competências para tal. Partiremos da noção de ritmo em uma perspectiva fundamentada na semiótica tensiva em considerações sobre este tema propostas por Greimas e Courtés (1986), Valéry (2007), Zilberberg $(1990,1996,2001,2011)$ e Tatit $(1998,2010 b)$. Finalmente, com apoio dos estudos sobre temporalidade realizados por Zilberberg e dos desenvolvimentos propostos por Tatit, empreendemos uma análise de seis interpretações de dois Noturnos de Chopin, sendo duas do opus 15 n. 3 e quatro do opus 27 n. 2, tendo como parâmetro de comparação o uso do tempo rubato durante as performances musicais. Nosso objetivo foi então estabelecer algumas diretrizes para se compreender os mecanismos de construção do sentido que resultam nos enunciados característicos do discurso musical, segundo as intenções de cada intérprete.

Palavras-chave: Tempo, Ritmo, Interpretação musical, Escuta, Tensividade. 


\section{Abstract}

\section{CÉSAR, M. M. Time and musical performance: A tensive hearing.}

2012. 117p. Dissertação - Faculdade de Filosofia, Letras e Ciências Humanas da Universidade de São Paulo, São Paulo, 2012.

The theoretical foundation of this work is based on the French line semiotics and its recent developments in tensivity theory. Our object of study is the variations of rhythm and tempo present in a sound text by approaching the plan of musical expression. The objective of this work is to understand how different performers articulate such discursive possibilities during the musical interpretation, based on the indications present in the music score. After initial considerations about the text and intertext in music, which purpose is to determine how these potentialities are manifested, we consider the time in different levels according to essays by Gérard Grisey (1987, 2004, 2008) and Messiaen $(1996,1995,1994)$. In a second moment we seek to articulate the different types of listening as discussed in studies conducted by Schaeffer (1966) and Greimas (2008). From these studies we define hearing as the act of doing, which requires the acquisition of skills to do so. This way we base this study on the notion of rhythm according to a perspective grounded in tensive semiotics found in previous work by Greimas and Courtes (1986), Valéry (2007), Zilberberg (1990, 1996, 2001, 2011) and Tatit (1998, 2010b). Finally, based on studies about temporality conducted by Zilberberg and further developments proposed by Tatit, we have analyzed six performances of two Nocturnes by Chopin (two performances of opus $15 \mathrm{n} .3$ and four other performances of opus $27 \mathrm{n}$. 2). During the analysis we compared the use of rubato time in the musical performance. The goal was to establish some guidelines to understand the mechanisms that underlies the construction of meaning which ultimately result in the characteristic enunciation of a musical discourse defined by the intentions of each performer.

Key-words: Tempo, Rhythm, Musical Performance, Hearing, Tensivity. 


\section{Lista de Figuras}

1.1 Hino Nacional Brasileiro, compassos 1-2. . . . . . . . . . . . . . . 12

3.1 Pierre Schaeffer, Traité des objets musicaux, 1966, p.116. - Quadro de funções da escuta. . . . . . . . . . . . . . . . . . 36

4.1 Formato da onda resultante da sobreposição de 3 harmônicos. . . . . . . . . 50

4.2 Série harmônica da nota dó. . . . . . . . . . . . . . . . . . . 51

4.3 Comportamento dinâmico da nota musical. Extraído de Meneses, 2004, p.29. 51

4.4 Dinâmica som-ruído e envelope musical . . . . . . . . . . . . . . . . . . 52

4.5 Compassos 1-8, III mov. Rondo -Vivace - Concerto para piano em fá menor de F. Chopin. . . . . . . . . . . . . . . . . . . 55

5.1 Waveform Noturno op.15 n.3 - MIDI. . . . . . . . . . . . . . . . . 70

5.2 Waveform Noturno op.15 n.3 - Guiomar Novaes. . . . . . . . . . . . . . . 70

5.3 Noturno op.15 n.3 - compassos 1-8. . . . . . . . . . . . . . . . . 71

5.4 Noturno op.15 n.3 - compassos 89-96. . . . . . . . . . . . . . . 71

5.5 Waveform Noturno op.15 n.3 - compassos 1-8, Guiomar Novaes. . . . . . . 71

5.6 Waveform Noturno op.15 n.3 - compassos 89-96, Guiomar Novaes. . . . . . 72

6.1 Noturno op.15 n.3 - compassos 1-4 e 89-92. . . . . . . . . . . . . . . 78

6.2 Balada op.52, F. Chopin - compassos 175-176. . . . . . . . . . . . 80

6.3 Noturno op.23 n.2, F. Chopin - compassos 44-45. . . . . . . . . . . . . . . 80

6.4 Noturno op.23 n.2, F. Chopin - compassos 1-3. . . . . . . . . . . . . . . 81

6.5 Noturno op.23 n.2, F. Chopin - Motivo do baixo. . . . . . . . . . . . . . 81

6.6 J. S. Bach - Prelúdio e Fuga II, v. II Cravo Bem Temperado. Compassos 22-28. . . . . . . . . . . . . . . . . 83

6.7 Prelúdio op.28 n.16, F. Chopin - compassos 28-35 . . . . . . . . . 83 


\section{Sumário}

Introdução 1

Escolha do objeto . . . . . . . . . . . . . . . . . . . . 1

Pressupostos teóricos . . . . . . . . . . . . . . . . . . . . 3

Tempo e tensividade . . . . . . . . . . . . . . . . . . 4

Apresentação dos capítulos . . . . . . . . . . . . . . . . . . . 7

1 Considerações iniciais $\quad 11$

1.1 Texto e discurso musical . . . . . . . . . . . . . . . . . . . 11

1.2 Partitura e interpretação: O intertexto na música . . . . . . . . . . . . . 15

1.3 Entrevista com Greimas . . . . . . . . . . . . . . . . . . . . . . . . 19

2 Modos de presença e temporalidade $\quad 22$

2.1 Presença, mapa e território sonoro . . . . . . . . . . . . . . . . . 23

2.2 Simulacros existenciais e duração vivida . . . . . . . . . . . . . . . 25

2.3 O corpo do tempo . . . . . . . . . . . . . . . . 27

3 O tempo do ouvinte 32

3.1 Entre o som e a escuta: os percursos do ouvinte . . . . . . . . . . . . 32

3.2 Por uma escuta missiva . . . . . . . . . . . . . . . . . . . . . . . . 39

3.3 Apreensão estética . . . . . . . . . . . . . . . . . . . . . . . . 42

4 Aspectos tensivos do plano de expressão musical 46

4.1 O timbre . . . . . . . . . . . . . . . . . . . . . 46

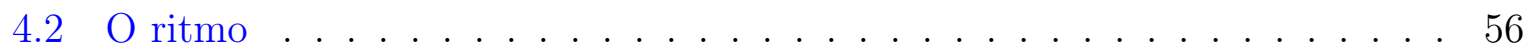

4.3 Tempo, forma e variação . . . . . . . . . . . . . . . . 58

5 O andamento na interpretação musical $\quad 62$

5.1 Cifras tensivas nas expressões de andamento . . . . . . . . . . . . . . . 62

5.2 O tempo rubato . . . . . . . . . . . . . . . . 67

5.3 Duas análises . . . . . . . . . . . . . . . . . . . . . . . 69

6 Quatro análises $\quad 73$

6.1 O Noturno Op.23 n.2 . . . . . . . . . . . . . . . . . . . . . . 73

6.2 Hemíolas, polirritmia e fatores de coesão . . . . . . . . . . . . . . . 78

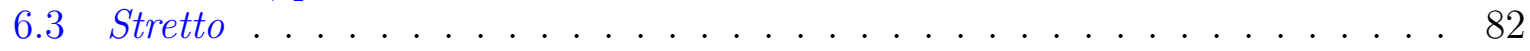

$\begin{array}{ll}\text { Conclusões } & 86\end{array}$

Referências Bibliográficas . . . . . . . . . . . . . . 89

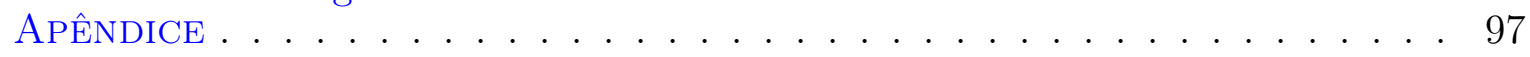




\section{Introdução}

\section{Escolha do objeto}

L'approche structurale n'a pas à definir le sens; [...] En usant d'une comparaison commode, la sémiotique n'est pas chargée de dire comment jouer, mais seulement qu'on peut jouer. Dans cette perspective, elle a pour finalité l'inventaire des possibilités que rien n'interdit au sujet de souhaiter le plus ouvert...possible. (Zilberberg, 1990, p. 40).

O objetivo geral desta pesquisa é compreender algumas das possibilidades de construção do sentido manifestado em um texto sonoro. Para isso, levaremos em conta aspectos relacionados à temporalidade presentes em diferentes instâncias do plano de expressão musical.

Como objetivo específico, pretendemos analisar os efeitos de sentido obtidos por meio das variações na percepção temporal, relativos à escuta e a gestualidade, em uma interpretação musical. Ao mesmo tempo, consideraremos também as expressões de andamento e ritmo presentes na partitura, as quais dizem respeito a potencialidades presentes na obra.

Assim, propomos inicialmente pensar o tempo segundo as diferentes instâncias em que ele se manifesta: (1) o tempo em relação a uma linguagem ou sistema composicional, relacionado ao momento da concepção da obra; (2) o tempo em relação ao modo de notação, por meio da escrita da partitura ou outros sistemas de escrita como a fita magnética; (3) o tempo interpretativo, em que o instrumentista irá realizar uma leitura própria da obra, e, finalmente, (4) o tempo perceptivo do ouvinte.

Por outro lado, tais tempos se inter-relacionam. Sabemos que todo compositor é o primeiro intérprete de sua própria obra, e também ouvinte. 
O intérprete, por sua vez, irá "recriar" este momento enunciativo segundo as marcas deixadas pelo compositor, além de realizar uma escuta atenta de sua performance, pré-requisito para seu bom desempenho. Já o ouvinte, quanto mais engajado com essa atividade, mais será capaz de compreender aspectos criativos e interpretativos da obra.

Assim, antes de determinarmos a existência de um tempo único, tentaremos relacionar esses momentos segundo a metáfora do "corpo do tempo" dividido em pele, esqueleto e carne pelo compositor Gérard Grisey, e denominando-os como modos de presença temporal, de acordo com a teoria greimasiana, a qual já previa tais tipos de relações como pertencentes a qualquer tipo de semiótica.

Por outro lado, percebemos a necessidade de um ajuste entre tais tempos, de modo que possamos falar em um tempo próprio de uma determinada obra. Dessa forma, assim como temos a exploração do tempo mnésico na música clássica, outras categorias do tempo passam a ser valorizados a depender do sistema musical utilizado.

De fato, a música moderna apresenta inúmeras situações em que é preciso reinterpretarmos os conceitos de ritmo, andamento, produção da espera e memória atribuídos à música ocidental dos períodos clássico e romântico. Ao mesmo tempo, reconhecemos que, em alguns compositores desses períodos, já podemos notar inovações no modo de escrita, as quais tanto antecipam como servem de forte influência para mudanças futuras.

Tal é o caso de Frédèric Chopin, autor de 21 Noturnos dentre os quais selecionamos algumas interpretações do op.15 n.3, e do op.23 n.2 para compor nosso corpus de análise. Para o primeiro Noturno, compararemos dois registros sonoros, um deles referente a uma execução realizada por um leitor de midi, e o outro, a uma leitura da obra proposta pela pianista brasileira Guiomar Novaes.

No caso do Noturno op.23 n.2, vamos comparar quatro registros, dois do pianista Maurizio Pollini ${ }^{1}$, realizados em épocas e contextos diferentes, e

\footnotetext{
${ }^{1}$ POLLINI, M. 18 Nocturnes. Deutsche Grammophon, 2005. 2 CDs. CHOPIN, F. Nocturne op.23 n.2. Disponível em: http://www . youtube.com/watch?v=6cxkLZoEFEk. Acesso em 09 dez. 2012.
} 
dois outros dos pianistas Luiz de Moura Castro ${ }^{2}$ e Arthur Rubinstein ${ }^{3}$.

\section{Pressupostos teóricos}

A linguagem é o meio pelo qual nossos sentidos têm acesso à percepção e compreensão das coisas que nos rodeiam. Ao considerar a música como uma linguagem, tomamos como base que, por meio dela, torna-se possível projetarmos um sentido, neste caso, de ordem estética, aos sons do mundo.

Sabemos que, embora o homem sempre tenha se interessado pela linguagem, foi a partir do início do século XX, em decorrência dos estudos de Ferdinand Saussure, que a ciência linguística foi criada como disciplina autônoma. Saussure se dedicou ao estudo das línguas naturais considerando-as não como uma coleção de etiquetas destinadas a nomear as coisas do mundo, mas sim como um sistema de signos cujo arranjo e cujas dependências têm um caráter arbitrário e autônomo em relação aos objetos, concretos ou abstratos, aos quais nomeiam.

Posteriormente, o linguista dinamarquês L. Hjelmslev, ao retomar e aprofundar os estudos de Saussure, estabeleceu as bases, ou os prolegômenos para a disciplina semiótica. Hjelmslev realiza assim, a expansão, já prevista por Saussure, dos conhecimentos adquiridos pelo exame das línguas naturais, criando uma verdadeira Teoria da Linguagem.

Tal teoria teve como continuador A. J. Greimas, o qual, na década de 60, retoma as investigações de Hjelmslev, dedicando-se ao estudo dos textos e propondo-lhes uma verdadeira gramática de cunho narrativo e discursivo. Greimas integra os dois modos de existência da linguagem, sistema e processo, e sua definição como união de duas formas, expressão e conteúdo, à compreensão do discurso transfrástico, ampliando o seu alcance teórico e suas possibilidades de aplicação em domínios não-verbais, como a música, a pintura, o cinema, a dança etc. Ao mesmo tempo, o objeto semiótico deslocou-se do estudo dos signos, segundo Saussure, para o estudo do processo de signi-

\footnotetext{
${ }^{2}$ CASTRO, L. M. Chopin Nocturnes. Rio de Janeiro: Digital Arts Studio, 2011. 2 CDs.

${ }^{3}$ RUBinstein, A. The Chopin Collection. RCA, 1991. 11CDs. Disponível em https://www . youtube.com/watch?v=E_2PjSzZ09o. Acesso em 09 dez. 2012.
} 
ficação imanente a todo e qualquer texto.

Além disso, embora inicialmente o modelo greimasiano tenha se apoiado nos conceitos narrativos fornecidos por V. Propp em sua análise dos contos maravilhosos russos e se estabelecido como percurso de ações (fazeres) realizadas pelo sujeito em busca de um objeto de valor, logo essa teoria começou a valorizar a competência modal do sujeito (ser) com o estudo das paixões. De fato, em trabalhos anteriores, Greimas já previa a necessidade de ajustes teóricos ao modelo que contemplassem a presença do "ser" perceptivo e sensível no discurso.

Claude Zilberberg foi o pesquisador que melhor respondeu aos anseios de Greimas fundando na semiótica um ponto de vista tensivo. Para tanto, o autor defendeu a prevalência do sensível sobre o inteligível, dedicando-se a construir dentro da teoria um espaço para a afetividade.

Nesse contexto, cumpre compreender como a tensividade articula essas duas dimensões humanas.

\section{Tempo e tensividade}

Preste atenção na cigarra cantando entre as árvores: primeiro se ouve uma série de notas precisamente definidas e claramente separadas, acelerando lentamente. Então, na medida em que o trinado ganha força, sente-se que as notas lentamente unem-se umas às outras; mas ainda cada trinado pode ser individualizado como parte elementar de um canto de flauta. Por fim, repentinamente, deparamo-nos com uma nota contínua que é o clímax do canto da cigarra até seu final. Agora observe o mar quando quebra na praia. Cada onda toma volume, precipita-se, e desaparece na areia. Podemos separar regularmente cada onda daquelas que a precederam e daquelas que a seguirão, e ainda cada onda individual é parte do contínuo do mar.

Assim é, em nossa experiência do dia-a-dia, a relação entre a continuidade e a ideia do discreto: às vezes a experiência da continuidade subjaz à do discreto e às vezes, o discreto leva ao contínuo. Sua relação é uma relação entre parceiros iguais. (Brolezzi, 1996, p.i apud da Costa, 1991/2, p.123).

Na obra $O$ som e o sentido, o ensaísta José Miguel Wisnik explica em que 
consiste a diferença entre as duas dimensões básicas de uma frequência sonora: duração e altura.

O bater de um tambor é antes de mais nada um pulso rítmico. Ele emite frequências que percebemos como recortes de tempo, onde inscreve suas recorrências e suas variações. Mas se as frequências rítmicas forem tocadas por um instrumento capaz de acelerá-las muito, a partir de cerca de dez ciclos por segundo, elas vão mudando de caráter e passam a um estado de granulação veloz, que salta de repente para um outro patamar, o da altura melódica. A partir de um certo limiar de frequência [...], o ritmo "vira" melodia. (Wisnik, 1989, p.20-21)

Assim, percebemos que há um certo momento de "viragem" entre o discreto, relacionado ao pulso, e o contínuo, ou o melódico, estando ambos, entretanto, intrinsecamente relacionados em uma composição musical. Ou seja, um nível depende do outro, funcionando como portador do outro. Segundo o autor, a compreensão desse momento chave, de passagem entre os dois estados, no qual o ritmo se torna melodia-harmonia, ou alturas, é imprescindível para a compreensão de ambas as dimensões pertencentes ao aspecto acústico da música (idem, op. cit., p.22).

O mesmo ocorre com nosso aprendizado numérico. Segundo Brolezzi (1996), discreto e contínuo são termos que se referem respectivamente a duas das ações básicas na elaboração da matemática: contar e medir. Assim, tomando como ponto de partida o fato de que "[...] não existe, no entanto, uma distinção cognitiva entre 'contar', e 'medir', e a relação entre ambos requer um estudo mais profundo." (Brolezzi, 1996, p.i apud Crump, 1993, p.136), o autor demonstra que podem surgir inúmeros problemas pedagógicos da tendência de se abordar os temas de matemática elementar optando por um ou outro aspecto, sem explorar a interação entre eles.

Nos estudos da linguagem, a relação entre grandezas contínuas e discretas vem sendo estudada por meio da teoria da tensividade. De fato, a alternância entre essas duas formas, passa a ser um dos parâmetros para a compreensão das mudanças de estado em um sujeito: 
Nossa vida afetiva tem necessidade de formas descontínuas para produzir trans-
formações súbitas de estado, sobretudo se este já decorre de longa e excessiva
duração. Do mesmo modo, quando em meio a mudanças desenfreadas, nosso
desejo se volta para as formas contínuas e desaceleradas que nos proporcionam
um tempo de convívio com o objeto. (Tatit, 1998, p.59-60)

Ao reconhecer a importância dos fenômenos contínuos, a teoria tensiva determina que toda manifestação textual pode ser analisada em duas dimensões do sentido, uma da ordem da intensidade e outra da ordem da extensidade.

Com a introdução na teoria do conceito de tensividade percebemos que esta, conjugando a intensidade e a extensidade, produz, ao projetar-se no espaço e no tempo, efeitos de fechamento/abertura ou de brevidade/alongamento do sentido. Com seu auxílio, o estudo das paixões passa a convocar tanto grandezas discretas e categoriais (modalizações) como grandezas contínuas e graduais (modulações).

Ao mesmo tempo, a determinação de um valor pertencente a uma dessas dimensões é feita segundo suas subdimensões, as quais são constituídas por tonicidade e andamento, no caso das grandezas intensas e temporalidade e espacialidade para as grandezas extensas.

Essa espécie de gramática possibilita relacionar as duas dimensões do sentido no que se denomina espaço tensivo. Assim, compreendemos a produção do sentido pelo modo como se dá a articulação entre o estado da alma (intensidade) e os estados de coisas (extensidade) num determinado texto.

Ao definir o andamento e a temporalidade como subdimensões da intensidade e extensidade, respectivamente, a teoria tensiva torna possível o estudo do ritmo discursivo, definindo o seu lugar entre as demais grandezas que estão presentes tanto em linguagens verbais quanto não-verbais, como a música. Segundo Zilberberg, dentre outras propostas, a tensividade "vise à la réconciliation du temps et de la structure, et plus précisément à mettre la souplesse de la structure au service du tempo." (1990, p. 37).

De fato, como aponta Tatit (1998), a semiótica tensiva, ao incorporar grandezas contínuas, tornou possível uma espécie de "musicalização da semiótica", não somente pelo fato de possibilitar a análise de componentes 
fundamentais à linguagem musical, mas também por trazer à luz o quanto todas as linguagens têm um pouco daquilo que na música reconhecemos de imediato, como o componente rítmico, as variações de andamento, a produção da espera e da surpresa, acelerações e desacelerações, e a propagação das intensidades. Diz o autor:

Sob esses aspectos — e não são os únicos — as relações entre pensamento se-
miótico e pensamento musical podem ser extremamente proveitosas para am-
bos os campos. Todos os modelos de análise musical baseiam-se nas formas
de identidade e desigualdade da progressão musical, nas formas de contração
e expansão do material melódico, nas regularidades intervalares, harmônicas
ou contrapontísticas etc., e, no entanto, jamais se propuseram a investigar o
lugar teórico desses conceitos que, em última análise, visam descrever o sentido. (Tatit, 1998, p.22)

Ao compreender que não apenas os discursos verbais, mas também as linguagens artísticas, manifestam tais ritmos, projetando no texto seu equilíbrio ou desequilíbrio afetivo, pretendemos somar a tais esforços, a compreensão do parâmetro interpretativo na música, acreditando que essa proposta possa contribuir para a compreensão de aspectos sensíveis do plano de expressão de um texto sonoro, resultante de uma performance musical.

\section{Apresentação dos capítulos}

Tomando por base a semiótica greimasiana, e suas bases linguísticas, reconhecemos a necessidade de realizar uma análise imanente da obra, a qual leva em conta o pensamento composicional manifestado por meio da partitura.

Entretanto, a semiótica de linha francesa, cuja fundamentação estruturalista tem frisado a importância da imanência desde as origens da teoria, aponta igualmente para a possibilidade de reconhecer algumas potencialidades já presentes no texto, neste caso, da partitura, caso levemos em conta o discurso sonoro que ele manifesta.

Assim, ao longo dos seis capítulos, ampliamos nossa abordagem inicial de acordo com o aspecto da obra que pretendemos desenvolver. 
No primeiro capítulo, realizamos inicialmente algumas considerações sobre o texto, o discurso e o intertexto na música, assim como o caráter emissivo e receptivo da enunciação musical, na tentativa de explicar o rumo dado a esta pesquisa em função da análise interpretativa de um texto sonoro.

Apresentamos também algumas considerações realizadas por Algirdas Greimas em entrevista concedida à rádio sob o tema da semiótica musical. Dentre os temas tratados pelo semioticista lituano, consta a forma temporal e sua relação com a linguagem musical, assunto que iremos retomar ao longo de nossa exposição.

No segundo capítulo, abordamos o tema da percepção do tempo, o que nos conduz ao estudo da presença, assim como à instância da potencialização. Nosso objetivo então foi desenvolver ambos os temas tomando a escuta como base para nossas reflexões. Levamos em conta o fato de que o tempo musical relaciona-se com o desenvolvimento do material sonoro, o que o torna passível de ser concebido em níveis. Compreendemos tais níveis segundo os modos de presença semiótica, utilizando alguns conceitos desenvolvidos na teoria tensiva.

A percepção temporal nos conduz igualmente a algumas reflexões de Gérard Grisey sobre o "corpo do tempo", visto segundo o esqueleto, a carne e a pele, aos quais acrescentamos ainda o "sangue do tempo", associando a cada um desses momentos, um modo de existência temporal. Temos assim, respectivamente, o tempo virtualizado, realizado, potencializado e atualizado.

No terceiro capítulo, dedicamo-nos à compreensão do tempo do ouvinte considerando para isso o ouvir como um fazer que exige de seu sujeito competências adquiridas de diversas maneiras. Após levantar considerações realizadas por teóricos e compositores sobre o assunto, acreditamos ser de interesse relacionar a "escuta reduzida" segundo esquematizada por Pierre Shaeffer, e que diferencia os verbos écouter, oü̈r, entendre, e comprendre, às competências adquiridas pelo sujeito que lhe possibilitam realizar uma escuta mais ou menos ativa.

Ao mesmo tempo, percebemos que a escuta, possui um caráter tensivo 
ao constatar, juntamente com Messiaen, que a percepção auditiva qualitativa de uma linha melódica difere com frequência de sua duração metronômica. Em outras palavras, o tempo é responsável pela organização dos acontecimentos sonoros sendo igualmente um reflexo deste, o que o remete tanto ao fazer e seu caráter emissivo, quanto ao ser, sendo este da ordem do acontecimento. Encerramos este capítulo com breves considerações sobre a apreensão estética.

No quarto capítulo, apresentaremos o timbre segundo seus componentes contínuos e descontínuos, o que já aponta para a presença de uma base rítmica, determinada por seu envelope sonoro. Comparamos assim, o comportamento do som musical ao modo como ocorrem as alternâncias entre abertura e fechamento vocálico em uma sílaba, cujo estudo, iniciado por Saussure e retomado por Hjelmslev, já no âmbito da semiótica, serviu de base para elaboração da teoria da tensividade por Claude Zilberberg.

Passamos em seguida para o estudo do ritmo, segundo suas bases tensivas. Assim, antes de definirmos o tempo, no singular, concebemos a existência de uma sobredeterminação de quatro dimensões temporais: cronológica, rítmica, mnésica e cinemática, cada qual responsável por um efeito de sentido específico, do qual depende o sentido resultante. Tais modalidades conferem uma direcionalidade ao discurso, atribuindo-lhe uma forma temporal.

No quinto capítulo, analisamos as expressões de andamento utilizadas na música, tomando como base sua cifra tensiva. Além das expressões que indicam andamento, outras expressões podem ser analisadas segundo o grau de (re)semantização gestual realizado pelo intérprete. Procuramos assim construir uma gradação considerando o nível tensivo e retomando a presença da intencionalidade interpretativa na construção de um sentido musical.

Analisamos ainda a expressão tempo rubato presente no Noturno op.15 n.3 de Chopin. Para tanto, comparamos duas interpretações, a primeira realizada pelo software timidity, leitor de midi, e a segunda executada pela pianista brasileira Guiomar Novaes ${ }^{4}$.

\footnotetext{
${ }^{4}$ NOVAES, G. Guiomar Novaes plays Chopin. Vox, 1995. 3 CDs.
} 
No sexto capítulo, nos dedicamos a algumas análises e aplicações da teoria exposta, retomando as considerações presentes no capítulo cinco a fim de analisar o fenômeno conhecido como stretto e a polirritmia, ou ainda a politemporalidade característica das hemíolas na música.

Terminamos esse capítulo com uma análise comparativa de quatro interpretações do Noturno op.23 n.2, de Frédèric Chopin. Duas delas realizadas pelo pianista Maurizio Pollini, em épocas e contextos diferentes e as outras pelos pianistas Luiz Castro e Arthur Rubinstein.

Concluímos com algumas observações e reflexões sobre o conjunto da dissertação. 


\section{Capítulo 1}

\section{Considerações iniciais}

\subsection{Texto e discurso musical}

Para justificarmos nossa trajetória de pesquisa, vamos inicialmente definir alguns termos pelos quais nosso objeto de análise será abordado. A primeira distinção a fazer é entre as noções de "texto" e "discurso".

Segundo Greimas texto e discurso são frequentemente considerados sinônimos. Neste caso, ambos os termos designam o eixo sintagmático, o qual determina as possibilidades combinatórias presentes em semióticas nãolinguísticas como, por exemplo, um balé ou um ritual. O sintagma pressupõe assim uma realização dentre as possibilidades ou potencialidades contidas em níveis anteriores de análise, caracterizados por um maior grau de abstração.

Neste trabalho, seguiremos a definição segundo a qual um texto vem a ser uma unidade de manifestação, um todo organizado de sentido definido por dois planos, a saber, expressão e conteúdo, sendo aquele a manifestação deste.

Nessa acepção, texto passa a ser sinônimo de corpus. Assim, temos que a linguagem verbal, ou seja, uma língua natural, é apenas um dos modos possíveis de manifestação textual. Esta pode ser tanto verbal, como nãoverbal ou sincrética, a depender da substância pela qual o texto se manifesta.

$\mathrm{Na}$ linguagem visual, o texto pode manifestar-se por meio de uma pintura ou uma escultura, e o cinema é um exemplo clássico de texto sincrético no qual duas linguagens, a sonora e a visual, interagem. Além disso, deli- 
mitamos o texto por dois brancos, ou seja, dois espaços de não sentido. O papel em branco antes e depois do texto, a moldura de um quadro, o início de um filme e a palavra fim delimitam o espaço de sentido e o de não sentido em diferentes linguagens.(Fiorin, 2012).

No caso da música instrumental, a notação musical delimita tradicionalmente o início do texto musical no primeiro compasso e o término na barra dupla. Consideramos a notação musical como resultante da enunciação realizada pelo compositor, a qual será manifestada visualmente.

Entretanto, se tomarmos o texto sonoro como uma interpretação do texto escrito, verificamos que sua execução deverá levar em conta alguns mecanismos necessários para a produção do sentido requerido pela obra.

Como exemplo, podemos citar a presença da anacruse em um compasso inicial, a qual requer do músico a realização de uma respiração ou produção de um tempo não escrito antes de iniciar a execução da peça, sendo tal recurso conhecido como um levare ${ }^{1}$.

Na verdade, tal recurso já é incorporado na linguagem musical e o citamos aqui com o intuito de apontar algumas diferenças que desenvolveremos mais adiante em nossas análises a respeito da relação intertextual (partitura e registro sonoro) que está presente.

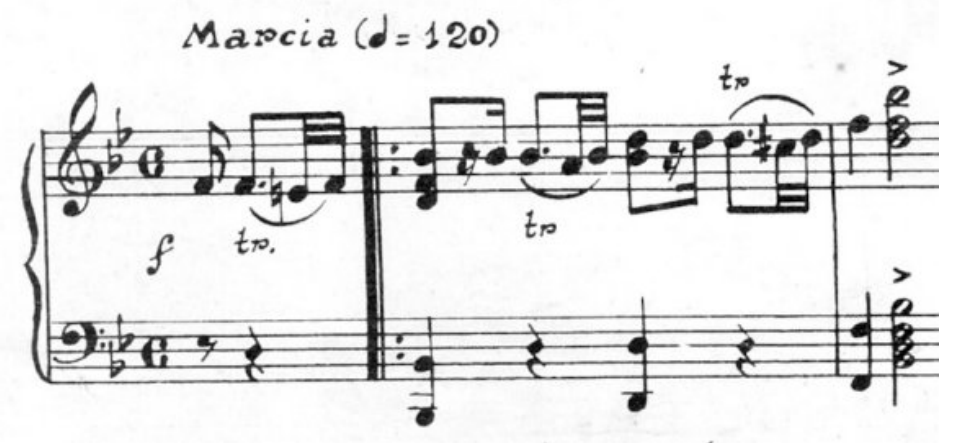

Figura 1.1: Hino Nacional Brasileiro, compassos 1-2.

\footnotetext{
${ }^{1}$ Musicalmente diferenciamos os ritmos tético, acéfalo e anacrúsico de acordo com o acento conferido à primeira nota de uma partitura. Enquanto o ritmo tético ocorre em um tempo forte do compasso, os ritmos acéfalo e anacrúsico ocorrem em um tempo fraco com a diferença de que, no caso do acéfalo, o tempo forte é substituído por pausas enquanto no anacrúsico ele não é escrito, mas está presente, devendo ser marcado por meio de uma respiração ou gesto do maestro.
} 
Por ora, é importante diferenciarmos o texto musical escrito, produzido pelo compositor, e o texto musical sonoro, que resulta de sua leitura ou interpretação. Neste caso, consideramos que o texto se inicia na faixa do cd ou do vídeo ou ainda na minutagem estabelecida para o registro do som, que invariavelmente incluirá o tempo da respiração realizada pelo intérprete ou o movimento de braço do regente marcando o primeiro tempo do compasso.

Segundo Fiorin 2008a, do ponto de vista da relação entre expressão e conteúdo, temos dois tipos de texto, aqueles com função utilitária, como informar ou explicar, e aqueles que têm função estética. No primeiro caso, a leitura é feita priorizando o plano do contéudo. Já nos textos com função estética, o escritor busca "recriar o mundo em palavras" de modo que importa não apenas o que se diz, mas o modo como se diz. Neste caso, o conteúdo é recriado na expressão e a compreensão da relação entre os planos é importante para a compreensão global do texto.

Além do caráter utilitário ou estético, um texto pode constituir um sistema simbólico ou semissimbólico, a depender das relações contraídas entre seu plano da expresão e seu plano do conteúdo (Fiorin, 2008a, p.49).

Em um sistema simbólico existe uma correspondência termo a termo entre os planos. Assim, por exemplo, uma bandeira é o símbolo de um país, e a cruz é o símbolo do cristianismo. No caso da música, temos que o Hino Nacional é símbolo do país, ou seja, este é o seu conteúdo, assim como a Internacional é o símbolo do comunismo. Isto ocorre independentemente da letra, embora esta possa contribuir para reiterar o conteúdo musical.

Temos um sistema semissimbólico quando é possível estabelecermos correlações não entre elementos, mas entre categorias dos planos da expressão e do conteúdo. No caso da canção, por exemplo, uma identidade entre motivos melódicos, decorrente de sua reiteração, pode corresponder a uma identidade entre sujeito e objeto (plena integração) no conteúdo da letra.

Fiorin (2012) reconhece uma diferença fundamental entre texto e discurso ao apontar que se trata de modos de existência semiótica diversos. Enquanto o texto seria da ordem da realização, ou seja, da manifestação, 
o discurso é da ordem da atualização e da imanência, ou seja, o texto é a manifestação do discurso por meio de um plano da expressão. Assim, ao mesmo tempo que um discurso pode ser manifestado por textos diversos, "certas relações que se estabelecem entre o texto e o discurso, dão uma dimensão sensível ao conteúdo, porque ele não é apenas veiculado pelo plano da expressão, mas recriado nele". (p.162)

Tais considerações iniciais foram levantadas, a fim de demonstrar algumas características que podem estar presentes em um texto musical. Neste trabalho, ao nos concentrarmos no fator temporal, buscaremos compreender um parâmetro comum aos diferentes tipos de manifestação do som musical, por meio do estudo de seu plano de expressão.

Por outro lado, ainda que consideremos ser frequente à música do período clássico e romântico a existência de fatores de ordem narrativa, levaremos em conta as considerações de Greimas a respeito:

não é mais do que um dentre os gêneros possíveis e algo extremamente raro na
música moderna, assim, minha sugestão seria analisar essas coisas separada-
mente. Há a narratividade do discurso mas é o autor que coloca certas doses
em lugares determinados e reorganiza, anacroniza tudo, e isso nos obriga a
proceder a duas análise distintas, que não devem ser confundidas ${ }^{2}$. (Entrevista
com Greimas - tradução nossa)

O que sugere a busca por um caminho paralelo, que torne possível compreender a apreensão do sentido na música. Dentre elas, tentaremos compreender a temporalidade segundo os parâmetros fornecidos pela semiótica tensiva, que estuda os níveis pressupostos pela narratividade e, ao mesmo tempo, os seus reflexos sobre os demais níveis.

\footnotetext{
${ }^{2}$ c'est n'est qu'un des genres possibles assez rare de la musique moderne, alors ce que je suggère c'est d'analyser ces choses séparement. Il y a de la narrativité du discours mais c'est l'auteur qui la met certaines doses à certains endroits et réorganise, anachronise tout, et ceci nous oblige à proceder a deux analyses distinctes à ne pas confondre.
} 


\subsection{Partitura e interpretação: $\mathrm{O}$ intertexto na música}

De modo geral, ao realizarmos a análise de uma obra musical, tomamos como base sua partitura. Entretanto, no caso da análise interpretativa, lidamos com o fato de que, o momento enunciativo, ou a atuação do intérprete, apresentará como resultado uma performance, quer em formato de recital, quer de uma gravação.

Como foi observado por Gerling, "os intérpretes frequentemente se voltam à análise de partituras a fim de obter respostas e suporte para decisões interpretativas"(Gerling, 2008, p.1), sendo esta também a escolha realizada na maior parte dos trabalhos acadêmicos em interpretação musical. Por outro lado, com os avanços tecnológicos ocorridos durante o século XX e a obtenção de um grande número de registros sonoros, já contamos com outra fonte de dados preciosa para o músico.

De fato, observamos que, desde a década de 90, a análise comparativa feita diretamente de gravações tem ganhado espaço entre os pesquisadores. Assim, embora se trate de uma área ainda em desenvolvimento no Brasil, já podemos citar como exemplos os trabalhos de Gerling (2008), Ulhôa (2006) e Matschulat (2011).

Além disso, podemos citar pesquisas recentes sobre a análise da canção, nas quais, segundo aponta Monteiro " $[. .$.$] a partitura (caso exista) é$ concebida como um tema a partir do qual o intérprete exercitará tanto sua expressividade quanto sua criatividade e senso estilístico num grau quase autoral [...]"(Monteiro, 2002, p.34).

Todas estas questões retomam um ponto crucial na formação do intérprete: o papel da análise musical para a compreensão de uma obra e construção de uma interpretação. Mais especificamente, pretendemos retomar algumas questões formuladas por Gerling (2008) sobre as bases das decisões tomadas por um intérprete.

O autor critica alguns dos aspectos "excessivamente racionais" pelos quais o intérprete deva supervalorizar o fato de estar constantemente engajado num processo de "análise da obra" de acordo com as ferramentas 
desenvolvidas pela teoria musical.

Na verdade, o problema principal reside no fato de se esperar que tais análises reconstruam uma imagem da música tal como ela deva ser executada, desconsiderando o fato de que algumas das escolhas feitas pelo intérprete seguem também uma base intuitiva.

Ao mesmo tempo, Gerling defende que esta "intuição" seja vista não como algo que se contrapõe à análise, mas como um fator a ser adquirido por outros caminhos como a escuta e observação de outras performances, como ocorre, por exemplo, com o aprendizado da língua falada.

Entretanto, pesquisas sobre a maneira como tal aprendizado ocorre são bastante recentes e ainda estão em fase de sistematização na área denominada musicologia empírica.

Além disso, já na década de 70, percebemos o surgimento dos primeiros textos dedicados à aplicação da teoria semiótica na música quando surgem também as primeiras preocupações relacionadas à interpretação:

Qu'est qu'un interprète? Pour nous encore, l 'interprète est là, il va de soi ; on discute seulement de la liberté que peut, que doit lui octroyer le compositeur. Mais l 'oeuvre n'est jamais ouverte, elle n'est qu'à demi-fermé (Jameux, 1975)

Por outro lado, conforme aponta Tarasti (1996), desde então a interpretação musical permanece como um dos domínios mais negligenciados da análise semiótica, em parte talvez pelo fato de ser comumente considerada como uma simples extensão dos meios habituais de análise musical.

Ao observar que desde 1932 o pesquisador Carls Seashore já havia elaborado métodos para medir e analisar gravações musicais, o autor se pergunta se existiria também um método capaz de abordar diretamente a interpretação de uma obra musical como processo produtor de sentido (Tarasti, 1996, p.271-272).

Ao realizarmos a análise de um texto musical resultante de uma interpretação, tomaremos a partitura como o texto-base a partir do qual o intérprete realizará a sua leitura, cujo resultado será um outro texto, desta 
vez da ordem do sonoro, que estabelecerá com o primeiro uma relação de intertextualidade.

Consideramos o texto-base como uma concretização do que Greimas denomina "instância da produção intertextual segundo o fazer emissivo", enquanto o texto concretizador ou as variantes intertextuais são as "estruturas interpretantes da intertextualidade segundo o fazer receptivo" (Greimas \& Courtés, 1986, p.122).

Segundo Discini (2002):

Ao observar uma variante intertextual, o analista não se deve prender, portanto, à expressão dessa heterogeneidade mostrada. O texto deve ser desbastado de suas significações aparentes, e, então vai-se (re)construindo o percurso percorrido em termos de relações das mais simples e abstratas às mais complexas e concretas. Aí, sim, examina-se a expressão, relacionada ao conteúdo. As marcas intertextuais mostradas no plano da expressão configuram-se, portanto, como absolutamente não-gratuitas, por ser geradas na imanência discursiva, por refletir formações discursivas, por revelar intenções do sujeito da enunciação. "Fora do texto não há salvação" (p. 18).

Assim, ao analisar um registro sonoro, não estamos desconsiderando o textobase, ou a partitura, mas sim procurando dar voz ao sujeito da enunciação que será, ao mesmo tempo que leitor deste texto, produtor de uma segunda enunciação, a qual abranje as condições em que ocorre esta produção.

Neste caso, a enunciação é resultante tanto das condições em que o enunciado foi produzido como da intencionalidade do sujeito, o qual conforme orienta o discurso, o faz segundo as possibilidades deste.

Tal afirmação levou-nos a projetar uma sequência narrativa (SN) da enunciação como construção do enunciado intertextual, mas isso não nos pareceu relevante. Vale é entendermos que há um sujeito que se deixa manipular pelo enunciado do texto-base, para querer captar sintática e semanticamente esse enunciado. Vale é pensarmos que esse sujeito pode ter outros quereres, como destruir esse enunciado e/ou destruir até a enunciação pressuposta nesse enunciado. Vale é descobrirmos que esse sujeito terá como performance a construção de um objeto-valor contratual (paráfrase, estilização), ou um objeto-valor polêmico 
(polêmica, paródia), caso entre em conjunção com os valores propostos pelo enunciado do texto-base ou em conjunção com seus próprios valores, discrepantes daqueles propostos. Vale é enxergarmos por trás de tais valores "os contextos de crenças e de consciência", que se confirmam ou se hostilizam, ou que se confirmam mesmo quando se hostilizam. (Discini, 2002, p.19)

Neste trabalho, tomamos como ponto de partida a hipótese de que há pontos de semelhança e variação entre o enunciado e a enunciação musical. O enunciado musical não se reduz à partitura (fora do uso) nem a enunciação à sua simples execução. A interpretação de uma peça (modos de tocar) pode inclusive alterar o sentido do enunciado e criar relações novas entre a expressão e o conteúdo musical.

Há, portanto, marcas do enunciado na interpretação assim como marcas da enunciação na partitura. Desta forma, a interpretação, ou leitura de um texto musical é o encontro do estilo do intérprete e das coerções do enunciado presentes na partitura. Constrói-se então um outro texto (interpretação musical) que se converte numa releitura do texto anterior.

Ocorre então uma espécie de relação de intertextualidade entre execuções de uma mesma obra em diferentes períodos da história e por diferentes intérpretes, ou ainda, de um mesmo intérprete em períodos diferentes de sua trajetória artística.

Além disso, a partitura musical não enuncia somente a obra, mas também seu autor na qualidade de sujeito da enunciação que selecionou uma determinada forma de escrever a obra (enunciado). Assim, em um primeiro momento, o compositor é o sujeito de um fazer emissivo cujo fazer receptivo ficará a cargo de seus inúmeros intérpretes.

Tais intérpretes se tornarão sujeitos de novos fazeres, ao atualizar os significados virtuais, já de ordem intertextual, uma vez que resultantes de referências anteriores adquiridas por meio da audição de outras interpretações ou composições. 


\subsection{Entrevista com Greimas}

Dado que a presente dissertação toma como base teórica a semiótica de linha francesa, gostaríamos de apresentar neste capítulo uma entrevista concedida à rádio por Greimas sobre o tema da semiótica musical datada de $1986^{3}$,localizada durante nossas pesquisas. Após realizarmos uma busca das fontes desta entrevista constatamos se tratar de um material pouco conhecido uma vez que não se encontra listado no levantamento razoavelmente abrangente feito por Kalandinskiene ${ }^{4}$ para o site Nouveaux Actes Sémiotiques sobre entrevistas, cartas e outros textos referentes a Greimas. Por este motivo, realizamos uma transcrição das duas partes da entrevista, com a finalidade de utilizar este material como citação ao longo desta dissertação ${ }^{5}$.

O tema da entrevista é a semiótica musical e nela Greimas discorre sobre pontos fundamentais como: A aspectualidade na música, o problema do timbre, o simbolismo no discurso musical, aspectos patêmicos na música, a correspondência entre as artes, o problema da notação musical, o conhecimento das formas temporais, relações entre o texto e o discurso musical, níveis de pertinência na música e a presença da narratividade.

Dentre os pontos tratados na entrevista que consideramos ser de interesse direto para o tema desta pesquisa, está a questão da aspectualidade na música e do que Greimas classifica como formas temporais. Além disso, o entrevistado sugere haver possibilidades de aplicação de resultados pertencentes às áreas da fonologia e fonética acústica na análise musical.

Greimas defende ainda que o significado musical possui um aspecto patêmico-cognitivo: "não podemos compreender este aspecto tímico ou patêmico como algo somente afetivo, há muito de cognitivo no passional e muito de passional no cognitivo". Também observa que há uma distinção entre as paixões da alma e as paixões do corpo.

Retomando o tema da aspectualidade, Greimas chama atenção para o fato de que a música clássica não seja inteiramente expressa por meio da

\footnotetext{
${ }^{3}$ www.semiotika.1t/category/audio-irasai/

${ }^{4}$ revues . unilim.fr/nas/document.php?id=2989\#tocfrom1

${ }^{5}$ Anexo A
} 
notação simbólica, visto que se vale também do uso de palavras ou expressões italianas. Sugere então que seja realizada uma classificação morfológica destas expressões, uma vez que elas fazem parte do discurso musical.

Greimas traça um paralelo entre as formas temporais e as formas espaciais, mostrando que essas últimas já estão bem definidas, sobretudo quando tratamos de formas geométricas. Não é raro que se comente uma fuga de Bach, identificando sua "arquitetura" interna, ou seja, traduzindo a forma temporal em modelo espacial. Entretanto, é necessário ainda definir como se constitui esta arquitetura musical, que tem como ordem sensorial privilegiada a temporalidade auditiva. Nesta mesma linha, poderíamos definir um significado para o termo "forma" para os casos em que este se refere a algo temporal, encontrando assim um denominador comum para essa expressão.

A questão das formas temporais é também o tema central das duas obras de Gisèle Brelet que fazem parte da bibliografia desta dissertação. Segundo a autora: "C'est au sein de la forme temporelle que se rejoignent l'expression et la forme : c'est elle qui éclaircit le mystére de leur accord."(1949a, p.471)

O conceito de forma já possui grande desenvolvimento na área da musicologia e, embora existam algumas divergências entre autores, podemos depreender um certo consenso no que diz respeito às formas de composição pertencentes aos períodos clássico e romântico como a forma sonata, rondó, tema e variações, formas binárias e ternárias etc. Entretanto, na produção moderna, muitas vezes a música não apresenta propriamente um desenvolvimento do seu material sonoro primário. Essa ausência de evolução narrativa de seus elementos, de reiteração temática ou de fraseados se torna um complicador na análise de algumas obras, o que não significa que tais composições não apresentem uma forma ${ }^{6}$.

\footnotetext{
${ }^{6}$ EMERY, 1975. Michel Imberty, "De la perception du temps musical à sa signification psychologique: à propos de "La Cathédrale engloutie" de C. Debussy," Analyse musicale 6 (1987): 29. Na obra Les écritures du temps, Imberty descreve a música de Debussy como "a música dos instantes e não da mudança [...] enquanto em Brahms nós temos um tempo retórico e discursivo, em que uma arquitetura temática organiza uma linha de fluxo contínuo, em que cada parte é extremamente dependente e decorrente da que a precedeu, em Debussy nós temos um tempo discontínuo, em que as partes não extraem seu significado do meio em que se inserem, mas do poder de evocação de reminiscências mais ou menos distantes, imobilizando ou quebrando o fluxo que desintegra no instante" Les écritures du temps (Paris: Dunod,
} 
Podemos perceber que Greimas já chamava atenção para a possibilidade de compreensão das formas temporais a partir da análise musical:

J'ai parlé du manque que la sémiotique éprouve et qui pourrait être seulement remplie par la contribution de la sémiotique musicale, c'est le peu de connaissance que nous avons des formes temporelles [car] la musique se développe dans le temps. Alors, en ce qui concerne les formes spatiales, je peux penser à l'analyse de la peinture, nous disposons des formes saisissables donc articulables et réductibles à des formes géométriques simples etc. [comme] une sorte de topologie. Alors, [une fois] que le temps c'est la spécialité en quelque sorte de la musique et de ces formes, nous en savons très peu de choses [sur ce plan], donc il faudrait qu'il ait cet apport de la musicologie pour qu'on puisse comprendre ensuite [si] les formes temporelles et spatiales sont réductibles à un dénominateur commun $[\ldots]^{7}$

Assim, devido à importância deste tema, pretendemos retomá-lo no final do quarto capítulo quando teremos então apresentado algumas ferramentas que permitem sua abordagem segundo parâmetros estritamente temporais, considerando o ritmo como um elemento estruturador.

1981), p. 113. - tradução nossa.

${ }^{7}$ Já mencionei uma falta que a semiótica apresenta e que somente pode ser sanada pela contribuição da semiótica musical, é o pouco conhecimento que temos a respeito das formas temporais, uma vez que a música se desenvolve no tempo. Assim, no que diz respeito às formas espaciais, eu posso pensar na análise de uma pintura, para a qual nós dispomos de formas tangíveis, logo, articuláveis e redutíveis a formas geométricas simples, etc., como uma espécie de topologia. Entretanto, uma vez que o tempo é a especialidade da música e de duas formas, nós sabemos muito pouca coisa sobre este assunto, assim, seria necessário esta abordagem musicológica para que pudéssemos compreender [se] as formas temporais e espaciais são redutíveis a um denominador comum [...] 


\title{
Capítulo 2
}

\section{Modos de presença e temporalidade}

\begin{abstract}
Evitando dizer $o$ tempo, tomamos como objeto a pluralidade dos estilos temporais possíveis. O tempo é um continuum, um não-sei-quê analisável, "enformável", orientável, enfim, passível de opor-se a si mesmo. O tempo é apenas a provisória soma de informações e operações que o universo de discurso considerado admite. A formulação mais justa a respeito do tempo genérico consiste em dizer que ele se presta a nós. (Zilberberg, 2011, p.124)
\end{abstract}

Real musical time is only a place of exchange and coincidence between an infinite number of different times. (Grisey, 1987, p.274)

Segundo Gisèle Brelet, no livro Le Temps Musical, diferentemente da pintura, poesia e artes dramáticas, incluindo a ópera, a música instrumental possui o status de arte essencialmente temporal, sendo mais próxima da dança como arte do tempo e do gesto ${ }^{1}$ Isto se explica pelo fato de que a forma musical consiste em uma espécie de "forma temporal pura" proveniente das durações vividas pelo compositor no momento da criação de uma obra. Tais formas podem assim ser atualizadas pelo intérprete por meio da técnica instrumental, estando esta sujeita ao domínio do gesto preciso dentro da duração psicológica que a duração musical busca resgatar. (Brelet, 1949b)

Para a autora, a ideia de duração psicológica por sua vez é o resultado da relação dialética entre a experiência do tempo vivido e o tempo pensado.

\footnotetext{
${ }^{1}$ Brelet retoma aqui considerações realizadas no século XVIII pelo filósofo G. E. Lessing ao defender a separação entre artes do tempo e do espaço. Na obra Laocoonte, em que o autor compara a poesia e a pintura, Lessing explicita condições específicas às quais cada arte estaria sujeita e defende que estas deveriam atentar para as coerções impostas por seu modo de expressão a fim de alcançar resultados mais produtivos.
} 
Assim, ao criar uma composição o compositor realiza um processo de ascese, uma vez que a duração psicológica não é o tempo musical, mas este tem como origem a busca por uma estrutura subjacente à primeira. A partir daí, considerando o intérprete no momento da leitura da obra, ao buscar compreender os sentimentos que esta lhe desperta, procurará chegar novamente à forma temporal subjacente a uma composição resgatando assim o tempo musical que lhe deu origem.

Tomando como ponto de partida as reflexões realizadas por Brelet, procuramos no capítulo anterior diferenciar estes dois momentos da enunciação musical nos quais ocorre, por um lado, a composição da obra, e, por outro, sua leitura ou interpretação, sendo esta realizada pelo instrumentista, ou simplesmente "intérprete".

Ao longo deste e do próximo capítulo nos dedicaremos entretanto a uma função fundamental para ambas as instâncias que é a posição de ouvinte. Para isso, analisaremos inicialmente a importância da percepção na apreensão da obra, de acordo com Grisey (1987). Para a semiótica, o tema da percepção nos conduz ao estudo do modo de presença e, dentro dele, à instância da potencialização. Pretendemos a seguir desenvolver ambos os temas tomando a escuta como base para nossas reflexões.

\subsection{Presença, mapa e território sonoro}

A noção de presença na semiótica, embora comumente problematizado em outras ciências, difere por definição de seu significado ontológico. Segundo Greimas "a presença (o "estar aî") será considerada como uma definição atribuída a uma grandeza, que a transforma em objeto de saber do sujeito cognitivo. [...] estão presentes, neste caso, todos os objetos de saber possíveis e a presença identifica-se, em parte, com a noção de existência semiótica."

Com relação aos modos de existência, reconhecemos inicialmente a existência virtual, ou in absentia, e a atual, ou in praesentia. "A passagem do sistema ao processo, da língua ao discurso denomina-se processo de atualização." (Greimas \& Courtés, 2008, p.195). 
Em um segundo momento, a semiótica reconheceu que os modos de existência virtual e atual não davam conta de designar a maneira de "estar aî" dos discursos-enunciados em ocorrência. Assim, foi necessário "reconhecer um terceiro modo de existência semiótica, que se apresenta como manifestação discursiva, devido à semiose, o da existência realizada" (idem, op. cit.).

Assim, temos definidos os modos de existência requeridos para uma semiótica da ação:

O problema da existência apresenta-se, enfim, em um outro nível, no próprio âmbito das semióticas consideradas e, mais particularmente, em relação aos discursos narrativos que se imagina descrevam situações e ações "reais". Embora reconhecendo que não se trata senão de simulacros de ações, das quais participam sujeitos "de papel", a análise exige que sejam tratados como se fossem verdadeiros: os seus diferentes modos de existência, as formas de suas atividades, uma vez descritos, podem servir, com efeito, de modelo para uma semiótica da ação e da manipulação. (idem, op. cit., - grifo nosso)

Entretanto, desenvolvimentos posteriores da teoria tornaram necessária a definição de um quarto modo de existência. A este quarto modo Greimas propôs denominar sujeito potencializado.

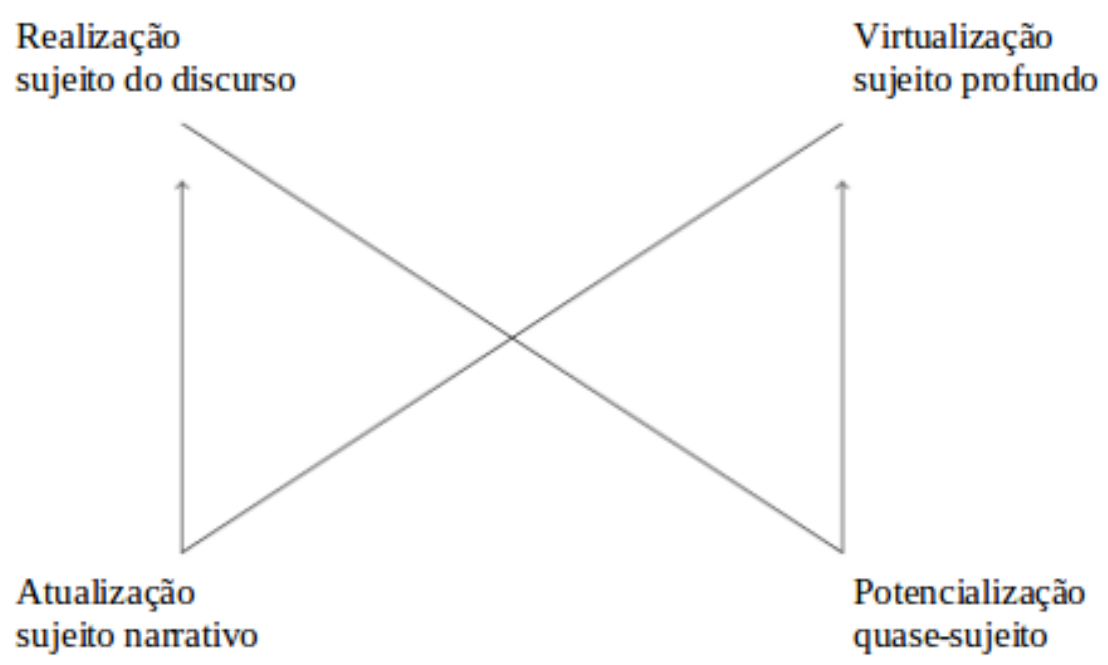




\title{
2.2 Simulacros existenciais e duração vivida
}

\begin{abstract}
A percepção, tal como a entendemos, mede nossa ação possível sobre as coisas e por isso, inversamente, a ação possível das coisas sobre nós. [...] A distância que separa nosso corpo de um objeto percebido mede portanto efetivamente a maior ou menor iminência de um perigo, o prazo maior ou menor de uma promessa. E, por consequência, nossa percepção de um objeto distinto de nosso corpo, separado de nosso corpo por um intervalo, nunca exprime mais do que uma ação virtual. Porém, quanto mais diminui a distância entre esse objeto e nosso corpo, tanto mais o perigo torna-se urgente ou a promessa imediata, tanto mais a ação virtual tende a se transformar em ação real. Passemos agora ao limite, suponhamos que a distância se torne nula, ou seja, que o objeto a perceber coincida com nosso corpo, enfim, que nosso próprio corpo seja o objeto a perceber. Então não é mais uma ação virtual, mas uma ação real que essa percepção muito particular irá exprimir: a afecção consiste nisso (Bergson, 1999, p.58).
\end{abstract}

Como vimos, a instância ocupada pela potencialização trouxe a necessidade de um rearranjo teórico a fim de que fosse possível admitir a existência de um sujeito passional. Em outras palavras, foi necessário prever modos de existência que descrevessem não apenas os estados de coisas, mas também aqueles característicos dos estados de alma. Neste momento a teoria passou a chamar a estes últimos de simulacros existenciais.

Para distinguir entre os dois tipos de funcionamento, conviria provavelmente designá-los de duas maneiras diferentes; reservando a expressão "modos de existência" àquilo para o que ela serviu em semiótica até o presente, denominaremos "simulacros existenciais" essas projeções do sujeito num imaginário passional (Greimas \& Fontanille, 1993, p.55)

Faremos a seguir algumas considerações referentes ao tempo musical segundo Messiaen no seu Traité de rythme, de couleur et d'ornithologie. Esta obra é dividida em sete volumes publicados a partir de 1994, sendo que as quatro primeiras partes, o autor dedica ao estudo do ritmo. Tal obra foi escrita ao longo de 40 anos, entre 1949 e 1989, período em que Messiaen escreveu e colecionou notas referentes ao papel do ritmo no discurso musical. 
Dentre as proposições feitas no Tratado, Messiaen considera que todas as substâncias no universo, incluindo os seres humanos, são feitas de tempos ou andamentos sobrepostos, assim teríamos o tempo abstrato e absoluto, o tempo relativo, o tempo quântico e o tempo humano (Messiaen, 1996, p.1820).

Messiaen sofreu grande influência de outros pensadores e filósofos que já haviam se dedicado ao tema da temporalidade como Henri Bergson e Gaston Bachelard.

O primeiro autor estabelece diferença entre tempo e duração, ou tempo real e tempo abstrato, simbólico. Para Bergson, enquanto o tempo abstrato se mede por meio do movimento, consistindo em uma justaposição com o espaço, o tempo real é uma sucessão (Bergson, 1999, p.75).

Ainda com base na proposta da duração segundo Bergson (1999), Messiaen estabelece diferenças entre o tempo psicológico, ou a duração vivida, e o tempo estruturado. Enquanto o primeiro é "concreto", uma vez que se confunde com nossos estados de consciência, heterogêneo, comportando acelerações e desacelerações, qualitativo e subjetivo; o segundo, chamado tempo estruturado, é de natureza abstrata, homogênea, quantitativa e objetiva (Messiaen, 1996, p.12).

Reproduzimos abaixo o esquema realizado por Messiaen (1996, p. 12), no qual é feita uma exposição comparativa entre o tempo abstrato e o tempo humano:

\begin{tabular}{|l|l|}
\hline \multicolumn{1}{|c|}{ Duraçâo vivida } & \multicolumn{1}{|c|}{ Tempo Estruturado } \\
\hline $\begin{array}{l}\text { A duraçâo é concreta } \\
\text { (estimada em relação a nós - ela se confunde com a a } \\
\text { sucessão de nossos estados de consciência) }\end{array}$ & $\begin{array}{l}\text { O tempo é abstrato } \\
\text { (tal qual uma moldura vazia, na qual nós colocamos o } \\
\text { mundo e nós mesmos) }\end{array}$ \\
\hline $\begin{array}{l}\text { A duraçâo é heterogênea } \\
\text { (ora rápida, ora lenta - com mil nuances de andamento, } \\
\text { uma prodigiosa variedade de lentidào e rapidez } \\
\text { diferentes) }\end{array}$ & $\begin{array}{l}\text { O tempo é homogêneo } \\
\text { (todas suas partes são idênticas) }\end{array}$ \\
\hline $\begin{array}{l}\text { A duraçâo é qualitativa } \\
\text { (É dependente de nossa natureza - nào mensurável) }\end{array}$ & $\begin{array}{l}\text { O tempo é quantitativo } \\
\text { (É mensurável, numerável - relativo aos fenômenos que } \\
\text { servem à sua medida: se esses fenômenos mudam, nossa } \\
\text { estruturação do tempo muda com eles) }\end{array}$ \\
\hline $\begin{array}{l}\text { A duraçâo é subjetiva } \\
\text { (dentro de nós) }\end{array}$ & $\begin{array}{l}\text { O tempo é objetivo } \\
\text { (fora de nós) }\end{array}$ \\
\hline
\end{tabular}


Propomos a seguir um esquema que reúne ambas as possibilidades, tomando como base a existência do tempo em relação ao sujeito (percurso temporal subjetivo) e ao objeto (percurso temporal real).

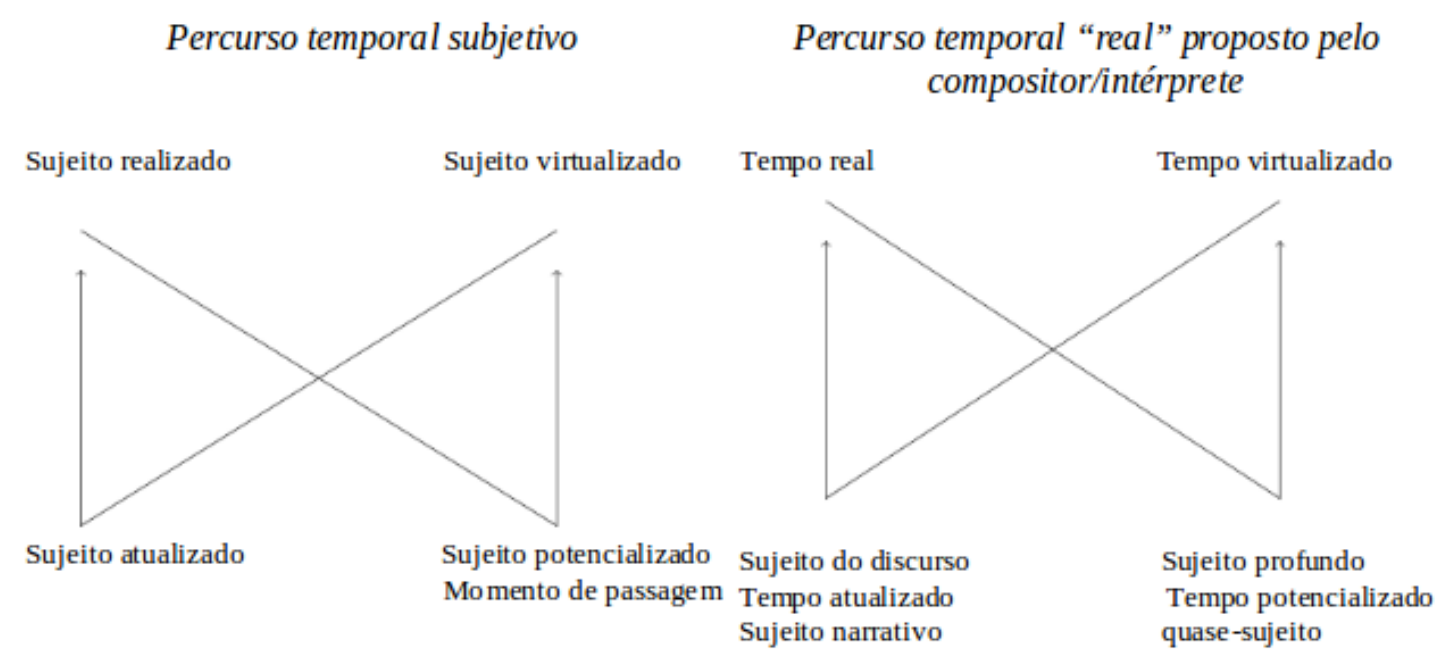

Ambos os percursos constituem simulacros uma vez que mesmo o tempo real, ou tempo absoluto, só nos é acessível pela audição e vivências que esta nos proporciona, variando, portanto, de acordo com o sujeito, o momento do percurso em que ele se encontra e o modo como ele percorre a construção do sentido.

Grisey vai sugerir que tal intuição se educa. Interpretamos tal fato como a possibilidade de se fixar estruturas musicais, neste caso, por meio de sua base temporal, e as reacessar por meio da memória. Sobretudo, o sujeito potencializado pertence ao domínio do crer, ou de uma troca intersubjetiva.

\subsection{O corpo do tempo}

O compositor Gérard Grisey é conhecido como um dos representantes da música espectral, estética que reavaliou os modos de organização dos parâmetros sonoros tomando como base o espectro harmônico da nota musical e a percepção desta pelo ouvinte. Além disso, o compositor dedicou-se igualmente à defesa de tal estética por meio da escrita de vários textos que tratam da importância estrutural do tempo na composição musical. Sobretudo o au- 
tor questiona a possibilidade real de um ouvinte perceber as inovações na música moderna, algumas delas resultantes de especulações de ordem formal referentes aos ritmos e durações:

\footnotetext{
Os músicos do século XX, como ocorreu com aqueles dos séculos XIV e XV, especularam muito sobre as durações. Aplicaram ao tempo proporções idênticas àquelas encontradas nas artes do espaço [...] Tais especulações, por mais úteis que sejam operacionalmente, estão sempre longe de chegar ao fenômeno sonoro tal como é percebido [...] terminaram por confundir o mapa com o território (Grisey, 1987, p.2 - tradução nossa).
}

Após problematizar e exemplificar tais questões, Grisey se propõe a construir uma teoria que possibilite relacionar as diferentes realidades que perpassam a existência, ou o território, de uma obra musical, ou seja, parte em busca de parâmetros perceptivos para compreensão da temporalidade. Para tanto, o compositor determina três tipos de abordagem do tempo na música, as quais, ele denominará: o esqueleto do tempo, a carne do tempo e a pele do tempo.

Por esqueleto do tempo, o autor define "o recorte temporal operado pelo compositor a fim de definir uma forma para os sons"(Grisey, 1987, p.1 tradução nossa), ou seja, neste caso, o compositor é visto como o responsável por gerenciar o tempo e a métrica em uma unidade de medida quantitativa, ou cronométrica, sendo sua unidade o segundo. Tal recorte gera uma forma. É o mapa da obra.

Por carne do tempo, Grisey define a percepção imediata do tempo e suas relações com o material sonoro, em uma unidade de medida mais qualitativa, em que o tempo é efetivamente um elemento de composição. Tais percepções se referem aos aspectos de contração e dilatação do tempo.

A contração pode ser causada, por exemplo, pela introdução de um acontecimento que perturbe a linearidade do discurso musical, provocando a surpresa. Já um grande grau de previsibilidade decorrente de uma série de acontecimentos similares causa a impressão de dilatação do tempo. Assim, o compositor deve ser capaz de lidar com a percepção auditiva relacionada aos acontecimentos sonoros.(idem, op. cit., p.12) 
A pele do tempo é o lugar de comunicação entre o tempo da obra e o tempo do ouvinte. Segundo Grisey "A pele do tempo, lugar de comunicação entre o tempo musical e o tempo do ouvinte, deixa muito poucas opções para sua ação. [do compositor]" (idem, op. cit., p.16 - tradução nossa). Neste caso o compositor deve tentar se colocar na posição de um ouvinte ou intérprete potencial de sua própria obra. Aqui entra em jogo o papel da memória com a qual o ouvinte possa, seguindo as pistas deixadas pelo compositor, reconstituir o tempo musical. A depender do nível de ambiguidade deste, o ouvinte pode ser levado à construção de um outro tempo musical mais ou menos de acordo com o tempo da obra.

Sobre esse aspecto, Grisey fala de uma "entropia auditiva" que força o compositor a recorrer à alguns artifícios de modo a introduzir uma ordem no discurso, sem a qual a própria noção de tempo fica comprometida. Dentre estes artifícios temos a repetição, as acentuações e contrastes ou "graus de pregnância dos sons", e o momento em que ocorre a passagem entre o tempo físico ou real e o tempo da música, ou seja, o início e o fim da peça "O ponto de união entre o tempo cotidiano e o tempo musical é particularmente rico em potencialidades. O começo e o fim de uma peça são pontos estratégicos de nossa memória" (Grisey, 1987, p.17).

O autor também menciona o efeito átono e tônico que tal momento pode exercer sobre nossa memória, segundo seu "nível de erosão".

A essas três abordagens do tempo, o autor ainda acrescenta:

[...] toda obra é o produto de uma imaginação temporal (o tempo de inspiração e do sonho), realizada em um tempo efetivo (o tempo da composição e da realização) e fixada em um tempo virtual (o tempo codificado da partitura, da banda magnética ou do programa de informática). Toda arte do compositor consiste em provocar um ajuste em fase destes tempos diferentes, um momento de sincronismo absoluto que atravessa de parte a parte tal politemporalidade (Grisey, 2008, p.179-180 - tradução nossa).

Aproximando tal concepção do tempo aos modos de presença ou existência semiótica da teoria greimasiana, consideramos este quarto momento de 
"ajuste de fases" como aquele em que ocorre a atualização, além disso, a tal ajuste consideramos denominar, o "sangue do tempo", devido ao seu caráter dinâmico em comparação ao esqueleto e à carne.

Temos assim, o seguinte esquema:

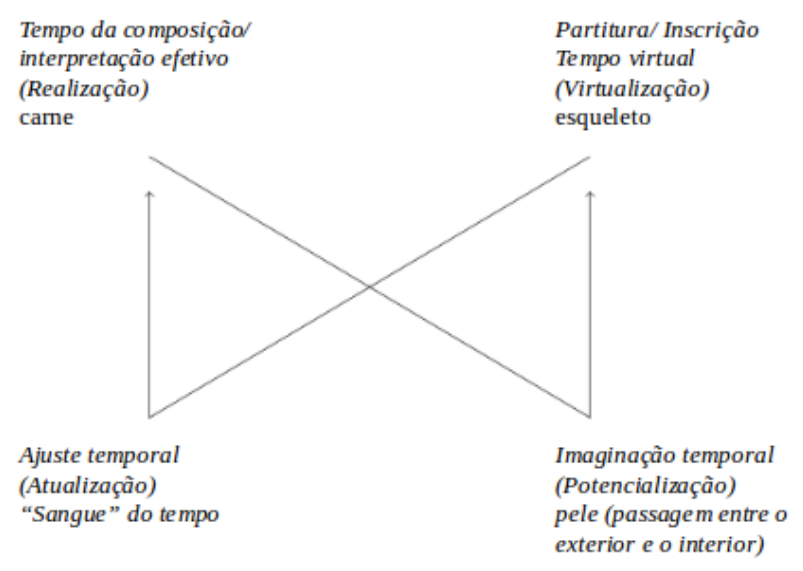

Para exemplificar esta aplicação nos servimos do desenvolvimento exposto por Gisèle Brelet (1951b) no livro L'interprétation créatrice, sob o tema do que a autora chama de incompletude da obra musical.

Segundo Brelet, uma obra musical nunca está "pronta", uma vez que sua aparência exterior e visível por meio da partitura não é senão um símbolo de seu ser interior, e isso exige que o intérprete resgate esta presença virtualizada na partitura.

Assim, o objeto musical não possui uma existência independente das ações executadas pelo compositor e intérprete. Enquanto podemos dizer que a pintura é uma realidade com existência objetiva e autônoma, ou seja, possui uma "quase-existência" anterior ao contato com um sujeito, a obra musical se encontra virtualizada até o momento de sua execução (Brelet, 1951b, p.2).

Por outro lado, segundo aponta o compositor Henri Pousseur, a respeito da técnica de grupos na música serial, ao diferenciar a série de uma de suas possibilidades de execução ou metamorfose, "a obra escrita, último grau de abstração antes do ato musical concreto, não pode mais ser identificada a nenhuma de suas atualizações particulares; ela é o lugar intemporal [hors temps] onde se encontra reunido certo número de possibilidades." (Pousseur, 2009, p.108). 
Assim, acreditamos ser necessário estabelecer esta diferença entre os níveis temporais dos quais uma obra musical participa, a fim de compreendermos suas especificidades e possibilidades de interação, segundo um percurso dinâmico que as relacione e torne possível a existência de um ajustamento, possibilitando um recorte particular característico da criação musical, tanto no sentido composicional quanto interpretativo (Brelet, 1951b). 


\section{Capítulo 3}

\section{O tempo do ouvinte}

\subsection{Entre o som e a escuta: os percursos do ouvinte}

Para a semiótica, um leitor designa a instância de recepção da mensagem ou do discurso, entretanto, dada a generalidade deste termo, é introduzida na teoria o conceito de enunciador. Desta forma, a estrutura da enunciação, sempre pressuposta pela simples existência de um enunciado, comporta a existência de um sujeito da enunciação, o qual recobre as posições de enunciador e enunciatário.

Portanto, ao considerarmos a necessidade de uma leitura imanente de um texto, o enunciatário é sempre previsto pelo sujeito da enunciação

\footnotetext{
É necessário excluir dessas considerações as condições psicofisiológicas dos leitores [...]: o enunciatário é por definição um actante conforme ao texto, e não uma classe inesgotável de atores individuais. Isto posto, admite-se que um mesmo texto pode conter diversas isotopias de leitura; em compensação, afirmar que existe uma leitura plural dos textos, isto é, que um texto dado oferece um número ilimitado de leituras, nos parece uma hipótese gratuita, tanto mais que é inverificável. (Greimas \& Courtés, 2008, p.282)
}

Por outro lado, sabemos que enquanto o enunciador é o destinador da mensagem, o enunciatário não é apenas o destinatário, mas também sujeito produtor do discurso, uma vez que a leitura se constitui um ato de linguagem, ou seja, passível de significar. A leitura, assim, constitui uma semiose. 
sentidos produzidos pelas sequências. Não é encontrar o sentido desejado pelo autor, o que implicaria que o prazer do texto se originasse na coincidência entre o sentido desejado e o sentido percebido, em um tipo de acordo cultural, como algumas vezes se pretendeu [...]. Ler é, portanto, constituir e não reconstituir um sentido. (Goulemot, 2001, p.108)

Entretanto, é necessário levar em conta o fato de que, enquanto performance, a leitura envolve a competência do leitor, sendo que esta pode diferir da competência atribuída ao produtor do texto.

\footnotetext{
Trata-se, com efeito, de procurar a conexão entre uma semiótica sistêmica e uma semiótica da leitura: para a primeira, todas as relações são internas ao dispositivo da língua. [...] A segunda reintroduz o sujeito do discurso e a dimensão intersubjetiva da interlocução no ato de leitura. Ela reencontra, por conseguinte, as questões colocadas especificamente, no domínio literário, pelas discussões clássicas sobre a interpretação e seus limites, sobre a polissemia nos textos, sobre a pluralidade das leituras. [...] Nessa perspectiva, o leitor não é mais aquela instância abstrata e universal, simplesmente pressuposta pelo advento de uma significação textual já existente, que se costuma chamar "receptor" ou "destinatário" da comunicação: ele é também e sobretudo um "centro do discurso", que constrói, interpreta, avalia, aprecia, compartilha ou rejeita as significações. (Bertrand, 2003, p.24)
}

No caso da música, ao considerarmos a produção sonora realizada por um instrumentista, temos, em vez de um leitor, um ouvinte. Assim, podemos transferir tais questionamentos a respeito do papel do leitor às possibilidades de escuta que um ouvinte possui em relação ao texto musical.

Segundo Greimas, podemos definir a leitura como uma construção, ao mesmo tempo sintática e semântica, do objeto semiótico que explica o texto-signo. Tal texto, entretanto, já possuiria potencialidades de sentido que iriam se definindo à medida de sua realização. Parafraseando os autores do dicionário, quando citam Barthes, a questão que colocamos é a de saber se uma dada música é suscetível de um tipo de escuta, de escutas múltiplas ou de uma escuta plural. (Greimas \& Courtés, 2008, p.283)

Essa mesma questão tem sido colocada por diferentes compositores e pensadores, dentre os quais, podemos citar Kramer (1988), Berio (Osmond- 
Smith, 1991), Boulez (1988), Schaeffer (1966) e Barthes (1982). Já Adorno (1994) esboçou uma tipologia da escuta, em que apresenta um estudo sobre os tipos de atitude musical, segundo indicadores sociológicos. Entre o ouvinte perfeito ou ouvinte-expert - capaz de compreender todas as intenções do compositor - até o ouvinte completamente indiferente, seguem-se sete outros tipos que o autor busca mapear.

Roland Barthes diferencia os termos entendre e écouter, destinando ao primeiro as relações de ordem fisiológica diante de um fenômeno sonoro, pelo qual percebemos a existência de um som, e ao segundo à ordem do psicológico, de acordo com três níveis diferentes:

Entendre est un phénomène physiologique ; écouter est un acte psychologique. Il est possible de décrire les conditions physiques de l'audition (ses mécanismes), par le recours à l'acoustique et à la physiologie de l'ouïe ; mais l'écoute ne peut se définir que par son objet, ou, si l'on préfère, sa visée.[...] pour simplifier à l'extrême, on proposera trois types d'écoute. Selon la première écoute, l'être vivant tend son audition (l'exercice de sa faculté physiologique d'entendre) vers des indices [...]. La seconde est un déchiffrement ; ce qu'on essaie de capter par l'oreille, ce sont des signes [...] j'écoute comme je lis, c'est-à-dire selon certains codes. Enfin, la troisième écoute [...] ne vise pas — ou n'attend pas — des signes déterminés, classés : non pas ce qui est dit, ou émis, mais qui parle, qui émet : elle est censée se développer dans un espace intersubjectif, où "j'écoute" veut dire aussi "écoute-moi". (Barthes, 1982, p.217 - grifo nosso)

Alguns anos antes de Barthes, Escal já colocara a questão da escuta em termos semelhantes: "En effet, l'écoute de la musique a trop souvent été comprise comme une opération passive de réception de l'œuvre, l'auditeur étant entièrement soumis au pouvoir du compositeur par-delà l'intervention de l'interprète. [...] l'écoute parle. Elle est active [...]". (Escal, 1979, p.186 - grifo nosso)

A partir deste breve levantamento, nos foi possível obter algumas sugestões de que a escuta possa ser tanto transitiva quanto reflexiva: Eu escuto a obra e eu observo os diferentes estados sensíveis que esta obra desperta em 
mim. Há um fazer proporcionado ao ouvinte por meio da escuta, o que implica uma aquisição de competências para tal.

O compositor Pierre Schaeffer (1966) vai propor a divisão da escuta em quatro tipos funcionais na construção do que ele define como écoute réduite uma vez que esta se concentra nas qualidades internas do som. Tal descrição toma como base a proposta de redução fenomenológica segundo Edmund Husserl. Schaeffer colocará de lado, ou entre parênteses, sua compreensão particular do som a fim de descobrir, segundo a percepção, o que não é revelado pela simples interpretação ou imaginação.

A discussão empreendida por Schaeffer parte de sua pesquisa musical, realizada na década de 40, do que mais tarde ficou conhecido como música concreta. Seu objetivo era então incorporar à música sons que normalmente não faziam parte da esfera musical, ou aqueles aos quais o autor denomina como o "oceano de sons" pertencentes ao nosso cotidiano.

Na escuta reduzida, o som se torna um objeto externo que possui sua própria realidade espaço-temporal, ele existiria portanto independentemente do ouvinte. Cabe ao homem percebê-lo ou não. Assim, tal escuta se traduz principalmente como uma proposta de ação.

A questão da escuta permeia toda a obra de Schaeffer, mas se encontra sintetizada no livro II do Traité des objets musicaux, de 1966. Nesta obra, a fim de nomear as diferentes funções da escuta, o autor toma emprestado verbos em francês referentes à audição: écouter, oü̈r, entendre, comprendre. O termo função, utilizado para definir esses verbos, implica que tais posturas se coordenam, ou seja, cada uma das escutas adquire um papel determinado em relação às demais.

Expomos no quadro abaixo algumas características de cada uma das funções. Levando em conta a pouca diferença de valor entre tais termos quando traduzidos para o português, uma vez que se trata de quase sinônimos, preferimos manter a sua versão original em francês. 


\begin{tabular}{|c|c|c|}
\hline $\begin{array}{l}\text { 4. COMPRENDRE } \\
\text { - pour moi : signes } \\
\text { - devant moi : valeurs } \\
\text { (sens-langage) } \\
\text { Emergence d'un contenu } \\
\text { du son et référence, } \\
\text { confrontation à des } \\
\text { notions extra-sonores }\end{array}$ & $\begin{array}{l}\text { 1.ÉCOUTER } \\
\text { - pour moi : indices } \\
\text { - devant moi : } \\
\text { évènements extérieurs } \\
\text { (agent-instrument) } \\
\text { Emission du son }\end{array}$ & $\begin{array}{l}1 \text { et } 4: \\
\text { objectif }\end{array}$ \\
\hline $\begin{array}{l}\text { 3. ENTENDRE } \\
\text { - pour moi : perceptions } \\
\text { qualifiées } \\
\text { - devant moi : objet } \\
\text { sonore qualifié } \\
\text { Sélection de certains } \\
\text { aspects particuliers du } \\
\text { son }\end{array}$ & $\begin{array}{l}\text { 2. OUĪR } \\
\text { - pour moi : perceptions } \\
\text { brutes, esquisses de } \\
\text { l'objet } \\
\text { - devant moi : objet } \\
\text { sonore brut } \\
\text { Réception du son }\end{array}$ & $\begin{array}{l}2 \text { et } 3: \\
\text { subjectif }\end{array}$ \\
\hline 3 et $4:$ abstrait & 1 et 2 : concret & \\
\hline
\end{tabular}

Figura 3.1: Pierre Schaeffer, Traité des objets musicaux, 1966, p.116. - Quadro de funções da escuta.

Assim, tomando como ponto de partida a relação sujeito - objeto sonoro, temos diferentes tipos de predicação que conduzem a uma escuta que pode se referir tanto a um fazer, enquanto escuta ativa, quanto ao ser, ou à escuta passiva, no sentido de que remete a um sujeito de estado.

Temos assim, em linhas gerais que:

1. Écouter: 1. É colocar o ouvido à disposição. Eu me dirijo ativamente a um objeto que me é apresentado por meio de um som. Compreendemos tal apresentação do som como um poder que lhe é dado, sendo este virtualizante, passível de ser atualizado em um dever, segundo o contexto em que este som é percebido.

2. Oü̈r: 2. É um ato puramente perceptivo, opondo-se neste sentido a écouter, o qual corresponde à uma atitude mais ativa. Aquilo que ouço é aquilo que me é dado na percepção. Desta forma o sujeito adquire um saber sobre o objeto. Diferencia-se também do entendre, o qual atualiza, pelo querer-ouvir, um som anteriormente percebido em uma instância abstrata, ou virtual.

3. Entendre: 3. Neste estágio ocorrem as qualificações, ou atualizações do ouvir, estando estas relacionadas a uma intenção. A própria origem 
etimológica da palavra entendre sugere o ato de "ter uma intenção. Aquilo que entendo, aquilo que me é manifesto, é função dessa intenção." Assim, compreendemos tal estágio como uma dimensão do querer.

4. Comprendre: 4. Emerge de uma qualificação do entender, é o ato de perceber um sentido pelo qual o som torna-se um signo, este por sua vez possui relações com um código cultural. Tal código cultural impõe-se ao sujeito como uma axiologia na qual um poder-ouvir atualiza-se em um dever-ouvir condicionado. (Schaeffer, 1966, p.104).

O que Schaeffer denomina escuta objetiva ou subjetiva, podemos entender em termos de exotaxia ou endotaxia. Enquanto / dever/ e / poder/ pertencem ao eixo das modalizações exógenas, /saber/ e /querer/ integram o eixo das modalizações endógenas. A explicação para tal é que /saber/ e /querer/ são movimentos que partem de dentro (querer) ou remetem para dentro (saber) do sujeito. Já o / dever/ e o / poder/ são articulados externamente ao sujeito, ou reúnem enunciados que têm sujeitos distintos (Greimas \& Courtés, 2008, p.315).

\begin{tabular}{|c|c|c|c|}
\hline Modalidades & Virtualizantes & Atualizantes & Realizantes \\
\hline Exotáxicas & Dever - Comprendre & Poder - Écouter & Fazer - Escuta Ativa \\
\hline Endotáxicas & Querer - Entendre & Saber - Oü̈r & Ser - Escuta Passiva \\
\hline
\end{tabular}

Grifamos no texto acima as diferentes competências adquiridas e manifestadas pelo ouvinte nas quatro categorias de escuta explicitadas por Schaeffer. Aquilo que me é apresentado (poder ouvir), aquilo ao qual me dirijo segundo uma intencionalidade (querer ouvir), aquilo que me é apresentado (saber ouvir) e aquilo que ouço segundo um código determinado, do qual participo (dever ouvir).

Observamos que tais funções não devem ser entendidas estritamente como etapas sucessivas de um processo, mas como modalidades de audição que podem ser obtidas em diferentes percursos que se complementam e podem 
ocorrer simultaneamente.

De um modo geral, compreendemos que o ouvinte será tanto mais ativo (ouvir/fazer efetivo) quanto mais competências lhe forem fornecidas pelo enunciador, o qual, enquanto destinador, pode ser tanto o compositor, autor da obra, como o intérprete, ou outras fontes externas a este, além do próprio ouvinte informado.

Propomos compreender estes quatro tipos de escuta segundo uma curva tensiva.

\section{Apreensão}
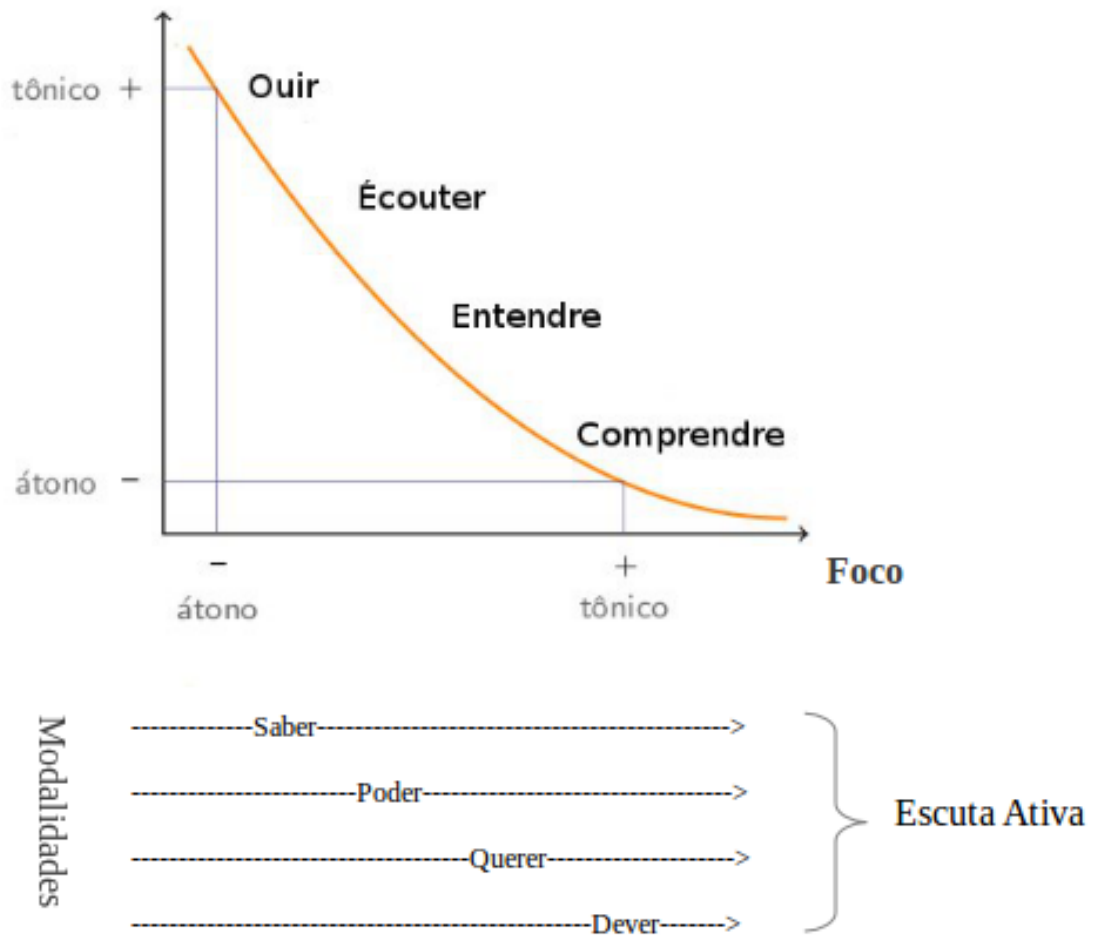


\subsection{Por uma escuta missiva}

Uma outra constatação feita por Messiaen no Tratado, de interesse particular aos propósitos deste trabalho, é o fato de que, caso nos aprofundemos nos parâmetros mencionados pela duração vivida, podemos constatar que a escuta qualitativa de uma linha melódica difere com frequência de sua duração metronômica.

Em outras palavras, o tempo é responsável pela organização dos acontecimentos sonoros sendo igualmente um reflexo deste. Tais relações são condensadas nas duas leis da duração vivida, de acordo com Cuvillier ${ }^{1}$ :

1. Sentiment de la durée présente: Loi: "Plus le temps est rempli (d'évenements), plus il nous paraît court - plus il est vide (d'évenements), plus il nous paraît long"

2. Appréciation rétrospective du temps passé. Loi inverse: "Plus le temps était rempli (d'évenements), plus il nous parait long maintenant - plus il était vide (d'événements), plus il nous paraît court maintenant." (Messiaen, 1996, p.23).

À apreciação retrospectiva do tempo passado, o autor relaciona a seguinte lei, chamada de ataque-duração, e já expressa por Souris² e Brelet (1949) como "Loi des rapports attaque-durée: à durée égale, un son bref suivi d'un silence paraît plus long qu'un son prolongé".

A explicação dada por Messiaen consiste no fato de que é preciso levar em conta que o silêncio preparatório para um som é uma utopia, que o silêncio isolado é uma exceção de ordem dramática e que a imensa maioria dos silêncios estão relacionados ao som que os precede. Ou seja, o silêncio é um acontecimento, mas de ordem diferente.

Embora em português chamemos pausas ao símbolo (figura de pausa de semínima, colcheias etc), elas não constituem pausas de fato, mas sim silêncios ${ }^{3}$, no sentido de que não há uma "pausa" nos acontecimentos, mas uma mudança, uma descontinuidade introduzida no som.

Mais adiante o autor cita Brelet:

\footnotetext{
${ }^{1}$ Tais leis foram extraídas por Messiaen do livro-texto de filosofia de Armand Cuvillier "Précis de philosophie: classe de philosofie" (Paris: Armand Colin, 1953).

${ }^{2}$ André Souris (1899-1979), compositor belga. Citado do artido "Notes sur le rythme concret" de 1948.

${ }^{3} \mathrm{O}$ francês manteve a mesma expressão silence para as duas ocorrências.
} 
Le souvenir, au lieu d'être irrémédiablement fixé, participe de la mobilité créatrice du temps, de la variabilité de nos attentes: à la lumière des nous souhaits actuels, le passé sans cesse change de signification... Attente et souvenir sont en intime liaison l'une avec l'autre : j'attends le retour du thème dans la mesure où je m'en souviens et je ne peut prévoir l'avenir de l'oeuvre qu'en me réglent sur mon passé. Et le souvenir des sonorités passés de la mélodie fait invinciblement surgir en moi une attente determiné, orienté vers certaines sonorités privilegiées, que je "reconnais" au moment où je les entends. En la durée musicale comme en la durée réelle, il y a prévalence de l'attente sur le souvenir, si le souvenir règle l'attente: l'oeuvre musicale, comme notre vie même, s'oriente vers l'avenir, et le souvenir n'a des sens en l'une et en l'autre que par l'attente qu'il suscite. Aussi l'attente est-elle le sentiment formel principal et central, celui qui sous-tend continuellement la forme sonore, avec lequel elle prend plaisir à se jouer, celui que en règle la technique même. (Messiaen, 1996, p. 25 apud Brelet, 1949b, p.572)

Podemos compreender tais relações situando o eu em um espaço mnésico. Neste, a espera passa a ser a memória do porvir e a lembrança a espera do passado. Zilberberg cita então Valéry segundo o qual "Uma nota espera a outra ou não a espera" (Zilberberg, 2001, p.15 - tradução nossa).

Tais relações nos remetem diretamente ao que Zilberberg denomina como fazer missivo. Para o autor, a missividade é dividida em dois fazeres: Um remissivo, o qual promove a parada, e um emissivo, o qual institui a parada da parada, ou a continuação. Assim, tal fazer comporta-se como um nível regulador das continuidades e descontinuidades da base de um discurso.

Diz-se que o fazer remissivo relaciona-se à cronopoiese (criação de tempo) porque o sujeito, estando em remissão, ou seja, parado, coloca-se em estado de espera. Já a cronotrofia (alimentação do tempo), fruto de um fazer emissivo, tem sua justificativa pelo fato de o sujeito estar em ação, alimentando o tempo com seu percurso de busca (Zilberberg, 2006, p.137). 


\begin{tabular}{|c|c|c|}
\hline \multirow{2}{*}{ Representação geométrica } & Remissivo & Emissivo \\
Dinâmica & Ponto $~$ & Linha Direcional $\longrightarrow$ \\
Tempo & Parada & Continuação (Parada da parada) \\
Espaço & Cronopoiese (gerar o tempo) & Cronotrofia (alimentar o tempo) \\
Memória & Fechamento & Abertura \\
Ordem do & Espera/Stase & Lembrança/Ek-stase \\
Remete ao & Acontecimento & Exercício \\
\hline
\end{tabular}

Messiaen cita ainda Souris (1948), segundo o qual, a segunda lei pode ser verificada ao executarmos uma mesma melodia em um xilofone e em um violino. O fato de que o tipo de ataque entre as notas executadas pelo xilofone seja diferente daquele obtido pelas mesmas quando sustentadas ao violino, embora o valor de tempo medido das notas da melodia seja idêntico, faz com que nossa percepção acredite que a melodia executada pelo xilofone pareça ser mais longa: "Percutée sur le xylophone, la mélodie se déroule dans une durée qualitativement plus longue que lorsqu'elle est soutenue sur le violon"(Messiaen, 1996, p.24). Em outras palavras, a quantidade de eventos na melodia executada pelo xilofone é maior quando comparada com aquela executada pelo violino, sendo tais eventos, portanto, um reflexo direto do timbre do instrumento.

Além disso, pode-se constatar que a duração percebida de uma mesma melodia, executada no mesmo tempo metronômico, pode se modificar devido a fatores como modos de ataque, instrumentação, tessitura, intensidades e dinâmica.

Acreditamos ser possível articular tais parâmetros musicais segundo seu grau de emissividade ou remissividade. No capítulo 6, retomaremos tal hipótese por meio da análise de algumas expressões musicais, assim como de interpretações na qual o instrumentista explora determinadas características do som, criando efeitos de sentido que envolvem o tempo e o espaço perceptivo do ouvinte. 


\subsection{Apreensão estética}

\footnotetext{
Quanto às ideias, são coisas de uma espécie que me é familiar; são coisas que sei observar, provocar, manobrar... Mas não posso dizer o mesmo de meus ritmos inesperados. (Valéry, 2007, p.199)
}

De tradição estruturalista, fundamentada nos estudos da linguagem, a teoria semiótica de linha greimasiana tem se ocupado ao longo do tempo com o estudo do sentido, não de um sentido qualquer, mas com o sentido que pode ser depreendido da leitura de um texto.

Entretanto, a preocupação em instituir novos parâmetros de reflexão, que tornem possível compreender o próprio surgimento do sentido, tem permeado tais estudos desde sua origem.

No Dicionário de Semiótica, Greimas já declara que "o conceito de sentido é indefinível", e, sendo assim, a semiótica se dedica ao seu estudo considerando que o sentido denomina aquilo que nos textos é suscetível de significar.

Já no final dos anos 80, a obra de Greimas apresenta uma espécie de "viragem estética" que se caracteriza pelas preocupações com a emergência do sentido, e suas condições estésicas, assim como a intencionalidade presente na imperfeição, sendo esta uma distância modal entre o ser e o parecer.

Tais preocupações são expostas no livro Da Imperfeição, cuja versão original francesa foi publicada em 1987, em que Greimas realiza algumas reflexões sobre a emergência do sentido, neste caso, não o sentido textual, mas a própria consciência do sentido na vida de um sujeito que vivencia um acontecimento estético, assim, "a imperfeição aparece como um trampolim que nos projeta da insignificância em direção ao sentido." (Greimas, 2002, p.91)

Tal sentido é resultante de um efeito da linguagem em discurso, não sendo descrito apenas como o êxtase sensível, mas como uma perturbação da narrativa acompanhada de uma fratura no sentido. O modo como o sujeito adentra tal experiência provoca uma fusão entre sujeito e objeto e permite 
ver de outro modo as coisas do cotidiano, provocando um deslocamento em um tempo/espaço até então familiares.

Além disso, o retorno à mesma ordem até então estabelecida não será mais possível uma vez que "o sujeito leva para o cotidiano a memória da experiência marcante e isto altera o seu sistema de expectativas, do mesmo modo que as realizações linguísticas imprimem suas marcas no sistema de línguas naturais." (Tatit, 2010b, p.57)

Podemos dizer que essa é a ambição própria do fazer artístico, ou seja, provocar uma mudança de perspectiva, causar um efeito de "deslumbramento" e inquietação, fazer o sujeito retornar aos seus fazeres cotidianos, mas com uma existência então ressignificada.

De fato, Greimas expõe em sua teoria como tais acontecimentos irrompem na descrição de textos literários. No primeiro deles, intitulado "O deslumbramento", o autor retoma trechos do conto Vendredi ou Les Limbes du pacifique, de Michel Tournier:

\footnotetext{
Robinson - O de Michel Tournier -, que até esse momento havia conseguido ordenar sua vida segundo o ritmo das gotas de água que caíam uma a uma de uma clepsidra improvisada, encontrou-se de repente despertado pelo "silêncio insólito" que lhe revelou "o ruído da última gota a cair na bacia de cobre". Constatou então que a gota seguinte, "renunciando decididamente a cair", chegou mesmo a "esboçar uma inversão do curso do tempo". Robinson se recostou de novo para saborear durante alguns momentos esta inesperada suspensão do tempo. (Greimas, 2002, p.24)
}

Para justificar tal descontinuidade, Greimas introduz a noção de escapatória e fratura.

Não se trata aqui, então, de uma simples troca de isotopia textual, mas de uma verdadeira fratura entre a dimensão da cotidianidade e o momento de inocência. A passagem a esse novo estado de coisas se manifesta como a ação de uma força que vem do exterior; o deslumbramento é, de fato, segundo os dicionários, o estado da vista golpeada pelo clarão demasiado brutal da luz. (Greimas, 2002, p.26) 
Assim, liberto das amarras do cotidiano o sujeito adquire a possibilidade de "dizer o indizível, pintar o invisível" e musicalmente, ouvir o inaudível. Neste trecho temos todas as condições necessárias para a ocorrência do deslumbramento que o personagem irá experimentar ao colocar-se de pé na moldura da porta.

Segundo Greimas, os constitutivos da apreensão estética dizem respeito ao grau de inserção na cotidianidade, à produção da espera, à fratura, e ao estatuto do sujeito e do objeto, assim como à relação sensorial que se estabelece entre ambos.

A apreensão estética aparece como um querer recíproco de conjunção, como um encontro, no meio do caminho, entre o sujeito e o objeto, no qual um tende ao outro. (Greimas, 2002, p.34). Enquanto os sons do cotidiano possuem um caráter utilitário, os sons contidos em uma prática impregnante podem ter seu sentido constantemente renovado, como expõe Valéry na passagem seguinte:

O poema, ao contrário, não morre por ter vivido: ele é feito expressamente para renascer de suas cinzas e vir a ser indefinidamente o que acabou de ser. A poesia reconhece-se por esta propriedade: ela tende a se fazer reproduzir em sua forma, ela nos excita a reconstituí-la identicamente. (Valéry, 2007, p.205)

De fato, tais acontecimentos, devido à sua natureza concessiva, são capazes de provocar a espera do inesperado.

A partir de Wölfflin, Zilberberg estabelece a diferença entre arte barroca e o estilo clássico. O clássico visa o acabado, o aparecido, enquanto o barroco, o inacabado, o aparecimento. Assim, "O primeiro é uma arte do ser enquanto o segundo, uma arte do parecer" (ZILBERBERG, 2011, p.43 apud WÖLFFLIN, 1989, p.24)4. Já segundo Kristeva, "o verossímil não tem senão uma característica constante: ele quer dizer, ele é um sentido" (1969, p.211-212)

Assim, temos a verdade como um termo complexo entre o ser e o pa-

\footnotetext{
${ }^{4}$ WÖLFFLIN, H. Conceitos Fundamentais da História da Arte: O problema da Evolução dos Estilos na Arte mais Recente. 2 ed. Trad. João Azenha Jr. São Paulo, Martins Fontes.
} 
recer do sentido.

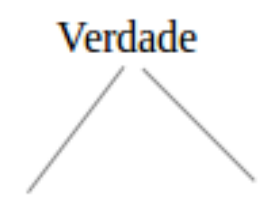

\section{Ser do sentido $\quad$ Parecer do sentido}

Ao mesmo tempo, Brøndal já havia apontado para o fato de haver um fator temporal que determina a passagem entre os dois subtermos de um termo complexo, o que lhe confere uma dinamicidade ${ }^{5}$.

Veremos no próximo capítulo que tal temporalidade, que ocorre na passagem do ser para o parecer, pode ser constituída de tempos sobrepostos, dentre os quais participa o tempo cronológico. A este constituinte temporal, atribuímos a possibilidade de uma inserção do sujeito no cotidiano. Assim, embora um acontecimento qualifique um estado de retenção, percebemos que tal estado é construído dentro das possibilidades de articulação temporal e de apreensão do objeto estético, permitindo a passagem entre os estados.

\footnotetext{
${ }^{5}$ Para Brøndal, [...] a sintaxe é do âmbito da oração e se preocupa com o "ritmo" e a "intenção" que a governam. Enfim, [...] o conhecimento da configuração de um sistema está a serviço da (ou dá origem à) inteligibilidade de seu devir. (Zilberberg, 2006, p.81)
} 


\section{Capítulo 4}

\section{Aspectos tensivos do plano de expressão musical}

\subsection{O timbre}

A matéria harmônica não é o único critério do timbre instrumental; geralmente, a forma dinâmica é ainda mais característica. (Schaeffer, 1966, p.52)

Embora se trate de uma obra não concluída, o livro Esquisses pour une méthode de piano (1993), do compositor e pianista Frédèric Chopin, nos serviu de ponto de partida para algumas reflexões sobre o timbre na música.

Essa obra, publicada em formato de notas acrescidas de comentários do editor, permite entrever alguns pontos de vista que Chopin possuía a respeito do ensino do instrumento, assim como da aproximação entre a música e a linguagem verbal.

Citamos abaixo as primeiras notas, transcritas à guisa de introdução pelo autor, que buscam estabelecer algumas definições consideradas fundamentais no aprendizado musical. Estas proposições são intituladas "Définitions de la musique - Principe de la double portée", ou princípios de semelhança entre a linguagem musical e a verbal:

L'art se manifestant par les sons est appelé musique.

L'art d'exprimer ses pensées par les sons.

L'art de manier les sons.

La pensée exprimée par les sons. 
L'expression de nos perceptions par les sons. [...]

La manifestation de notre sentiment par les sons. (Chopin et al., 1993, p.48)

Com estas primeiras considerações, que expõem as preocupações de Chopin em estabelecer diferenças entre a expressão e o conteúdo musical, além de identificar o som como sua substância de expressão, o autor prossegue:

\footnotetext{
La langue indéfinie [:] la musique.

La parole naquit du son - le son avant la parole.

La parole [:] certaine modification du son.

On se sert des sons pour faire de la musique comme on se sert des paroles pour faire un langage. (Chopin et al., 1993, p.48)
}

Essas afirmações já são em si instigantes para o pensamento musical, mas a preocupação com o ensino e fixação de tais princípios, em especial o depreendido pela leitura da última frase, nos sugere que a compreensão de algumas estratégias da escrita composicional de Chopin possa ser obtida por pesquisas que digam respeito ao papel do som na linguagem verbal.

Assim, faremos a seguir uma aproximação entre os conceitos utilizados na música, em especial o conceito de timbre, ataque e campo harmônico, com resultados obtidos em estudos fonológicos, segundo seu aproveitamento na área da semiótica. Partiremos dos estudos realizados por Carmo (2005) e Pietroforte (2008), com base na teoria glossemática de Louis Hjelmslev (1975) e, em particular, nos conceitos de caracterizantes e constituintes.

Para tanto, definimos elementos caracterizantes como aqueles que, em uma cadeia sintagmática, possuem a faculdade de determinar outros elementos, estabelecendo uma relação obrigatória. Já os elementos constituintes são definidos como aqueles em que tal determinação não é obrigatória, ou seja, a relação entre estes e os demais elementos do sintagma é facultativa.

Ainda de acordo com a teoria glossemática, e com o seu princípio de isomorfismo entre os planos da linguagem, Carmo (2005) demonstra que, por fazerem parte tanto do plano da expressão do plano do conteúdo, tais elementos são fundamentais para a sua definição: 
O mecanismo da linguagem constrói-se em torno da dependência entre constituintes e caracterizantes, dependência esta que remotamente liga-se às divisões clássicas entre morfologia (constituintes do plano do conteúdo) e sintaxe (caracterizantes do plano do conteúdo) de um lado, e fonemática (constituintes do plano da expressão) e prosódia (caracterizantes do plano da expressão) de outro. (Carmo Jr, 2005, p.17-18)

Portanto, na visão hjelmsleviana, os caracterizantes têm como função estabelecer conexões entre os constituintes por meio da "força de relação" adquirida na cadeia sintagmática. Por exemplo, o acento tônico é determinante em relação ao acento àtono, determinado. Tal fato segue uma lei prosódica, que o falante não tem liberdade de modificar, uma vez que o que distingue a língua da fala é a liberdade de combinação conferida por seus caracterizantes. Ou seja, os constituintes referem-se ao sistema, enquanto os caracterizantes, ao processo.

Partindo das mesmas relações, Pietroforte (2008) irá diferenciar a função das vogais e consoantes em uma sílaba linguística, segundo sua função de elemento constituinte do plano da expressão. Para tal, verifica que "na formação dos sons, as vogais devem formar ondas sonoras regulares, enquanto as consoantes formam ondas sonoras irregulares." (Pietroforte, 2008, p.136). Deste modo, enquanto as vogais formariam os sons, as consoantes são responsáveis pelos ruídos.

Além disso, o autor observa que

Junto com a propriedade de formar sons, as vogais possuem um aspecto durativo que, além de participar da formação das vogais, participa também da formação de algumas consoantes. Ao formar os ruídos, as consoantes podem ser articuladas de dois modos básicos, ou são oclusivas e têm um aspecto pontual, ou são durativas e têm um aspecto durativo, como é o caso das vogais. Não são apenas algumas consoantes que têm propriedades comuns às vogais, pois algumas vogais têm propriedades consonantais. As semi-vogais estão no limite da transformação da articulação dos sons na articulação dos ruídos, na medida em que o som que são capazes de formar não ocupa o centro, mas as margens das sílabas na formação de ditongos e tritongos. (idem, op. cit.)

Em seguida, é articulada a passagem entre as vogais/semivogais/consoantes 
durativas/consoantes oclusivas segundo o quadrado semiótico som vs. ruído reproduzido abaixo:

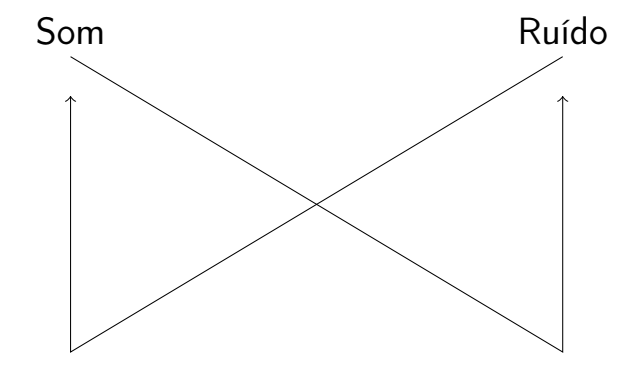

Não-ruído

Não-som

Devemos entretanto observar o fato de que a denominação de soantes atribuída às vogais deve ser sempre avaliada de acordo com a relação que estas estabelecem com as consoantes, não sendo portanto um valor absoluto. Tatit observa que

um "i" desempenha a função de soante na palavra "fidalgo" mas de consoante na palavra "piegas", na medida em que, nesta última, o "e" - pronuncia-se é (e aberto) - que lhe segue assume o papel de soante e faz do "i" anterior, de sonoridade mais fechada, um limite, ou seja, uma consoante. Isso deixava claro que o importante para o mestre de Genebra eram as leis de abertura e fechamento do som que geravam as funções de soante e consoante e não a qualidade material de cada fonema, sujeita a alterações a depender do contexto.

(Tatit, 1994, p.242)

Uma observação de Pietroforte (2008), de interesse particular à nossa pesquisa, é o fato de que tal categoria, devido ao seu caráter abstrato, "não se reduz apenas à formação do sentido na expressão linguística. Ao tratar do som vs. ruído, ela abrange o sentido de qualquer expressão feita por meio de sons, como, por exemplo, é o caso do plano da expressão do sistema semiótico musical." o que permite acrescentar que "Em termos tensivos, o som tem uma profundidade extensa, já que por meio de sua forma é possível manter continuidades, e o ruído é intenso, já que por meio de sua forma é possível pontuar descontinuidades." (Pietroforte, 2008, p.137) 
Pretendemos a seguir relacionar tais considerações linguísticas, que já acenam para possibilidades de aplicação na teoria semiótica, e em particular para a semiótica musical, a algumas considerações de ordem acústica a respeito da produção do som e do timbre.

Com relação à fonte sonora, a acústica distingue os instrumentos musicais segundo o modo de produção do som, o que implica um sistema com três elementos: Um mecanismo de excitação, um elemento vibrante e um ressonador. A função que tais elementos exercem é respectivamente de suprimento de energia, determinação das características do som fundamental e conversão das oscilações de pressão do ar (ondas sonoras), o que determina as características finais do som. (Roederer, 1998a)

O suprimento de energia inicial é responsável pela produção do ataque, enquanto o elemento vibrante e o elemento ressonador determinarão a forma final que o som possuirá. Entretanto, assim como ocorre com as vogais e consoantes, o ataque e a ressonância do som podem sofrer interferência mútua (Menezes, 2004, p.222)

O timbre de um som é atualmente representado por suas oscilações internas, ou harmônicos obtidos, e ao modo de permanência de tais variações, ou seu envelope, segundo os transientes produzidos.

Por harmônicos entendemos que, sendo um som complexo, a nota musical implica a produção de um som fundamental seguido pelas notas de seu espectro, segundo o esquema abaixo.

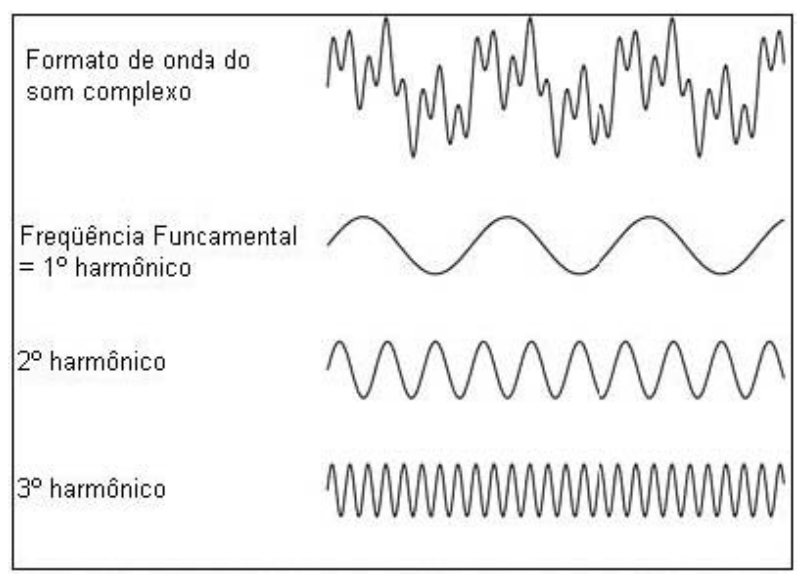

Figura 4.1: Formato da onda resultante da sobreposição de 3 harmônicos. 


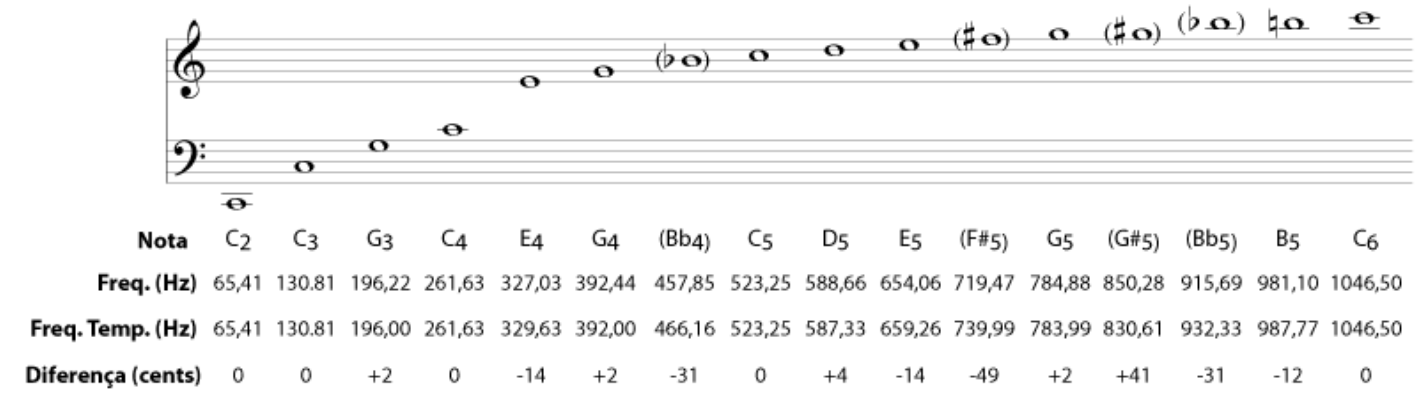

Figura 4.2: Série harmônica da nota dó.

Tais frequências irão soar a intervalos regulares conferindo uma "cor" particular ao som resultante. A compreensão de tal propriedade do som tornou possível a construção dos atuais sintetizadores utilizados em instrumentos eletrônicos, como o piano digital.

Além disso, qualquer momento que indique uma alteração da amplitude é denominado transitório ou transiente, devido justamente ao seu caráter descontínuo. Isto ocorre porque as vibrações que compõem uma nota não se iniciam em sua amplitude ou intensidade máxima, mas necessitam de alguns ciclos para atingi-la, sendo tal evolução dependente do tipo de ataque ou do transiente inicial de tal nota.

Enquanto a representação dos harmônicos de uma nota em instrumentos digitais já é uma realidade, a reprodução do ataque apresenta uma dificuldade à parte, uma vez que, embora este também interfira no som por meio dos transientes produzidos juntamente com os seus harmônicos, tal interferência depende da perturbação inicial, a qual é difícil de prever antecipadamente, uma vez que esta funciona como um sistema caótico.

Primeiros $100 \mathrm{~ms}$ de (a) uma corda de violoncelo; (b) uma corda de piano;

(c) uma membrana de percussão

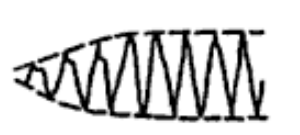

(a)

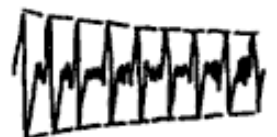

(b)

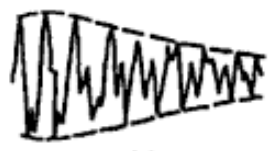

(c)

[cf. Campbell \& Greated]

Figura 4.3: Comportamento dinâmico da nota musical. Extraído de Meneses, 2004, p.29. 
Podemos assim fazer uma aproximação entre o modo de comportamento do som musical e a dinâmica do som e do ruído que estabelecemos anteriormente. Com o mapeamento do envelope dinâmico do som, foi possível precisar que ele possui ao menos quatro fases principais: o ataque, ou momento inicial do som, a primeira queda, ou perda de energia ocorrida logo após a grande quantidade de energia liberada no transiente de ataque, o regime estacionário, de permanência ou sustentação, e a queda final, com o esvaecimento do som. Ou seja, as mesmas continuidades e descontinuidades observadas na fala, podem ser observadas em um único som musical.
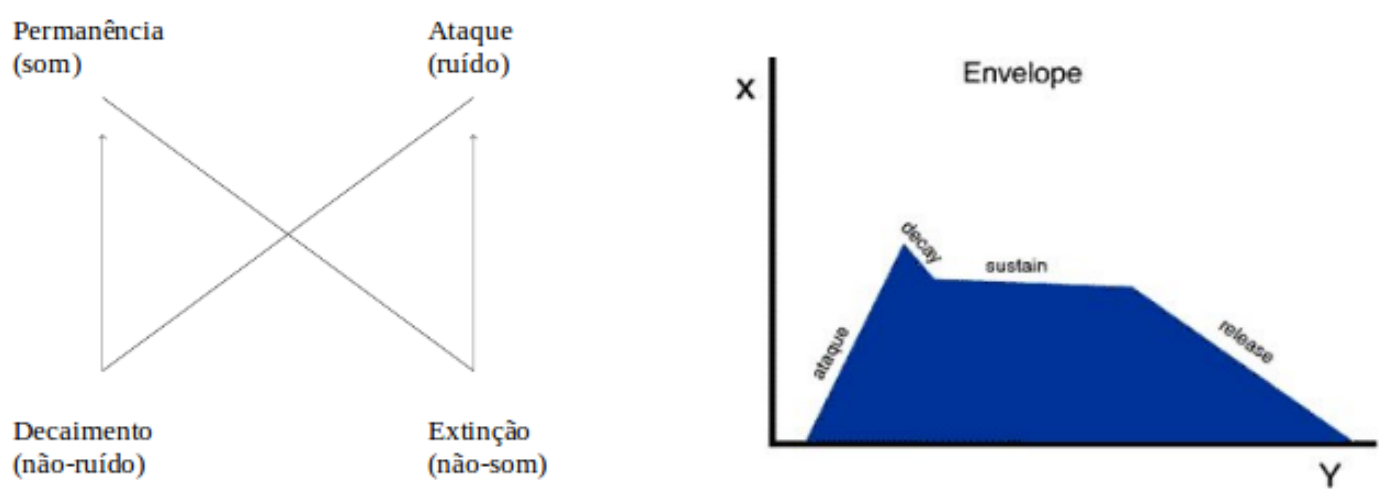

Figura 4.4: Dinâmica som-ruído e envelope musical

Percebemos deste modo que toda nota é resultante do tom fundamental, acrescido dos seus harmônicos e do envelope. Os dois últimos determinam seu timbre. Entretanto, enquanto o primeiro é dependente da altura da nota, o segundo depende em parte de sua duração ou modo de sustentação, e o último já é totalmente dependente das continuidades e descontinuidades que esta nota apresentará.

Retomando as considerações anteriores a respeito das vogais e consoantes e sua articulação em termos de som e ruído, compreendemos que o ataque de uma nota em um instrumento, assim como a produção das consoantes na linguagem verbal, está próximo do ruído, o qual é da ordem da descontinuidade. Ao mesmo tempo, a sustentação da nota musical, possui um correlato semântico no som, gerando continuidade. 
CAPÍTULO 4. ASPECTOS TENSIVOS DO PLANO DE EXPRESSÃO MUSICAL 53

\begin{tabular}{|l|l|l|l|l|}
\hline $\begin{array}{l}\text { Constituintes do PE } \\
\text { Linguístico (Sílaba) }\end{array}$ & $\begin{array}{l}\text { Constituintes do PE } \\
\text { Musical (Nota/Grupo de } \\
\text { notas) }\end{array}$ & $\begin{array}{l}\text { Correlato } \\
\text { Semântico }\end{array}$ & Aspecto tensivo & Profundidade \\
\hline Soantes & Harmônicos & Som & continuidades & Extensa \\
\hline Consoantes & Ataque/Transientes & Ruído & descontinuidades & Intensa \\
\hline
\end{tabular}

Podemos considerar que tal propriedade do som serviu de base para o estabelecimento de leis harmônicas como consonâncias e dissonâncias assim como as escalas de afinação, caso levemos em conta as propriedades resultantes da interferência entre as ondas acústicas.

Segundo Tatit (2007), no desenho, embora os traços possuam a tendência de configurar espaços e volumes, "a função delimitativa dos traços está sempre à serviço da ocupação dos espaços e vice-versa, de maneira que ambas podem chegar a ter seus valores de origem consideravelmente alterados". $\mathrm{Na}$ geração de um som ocorre algo semelhante com relação aos transientes que este possui, sendo estes responsáveis por "conduzir nosso olhar aos espaços e volumes", ou aos harmônicos, que definem um timbre.

Um outro ponto pode ser levantado, caso consideremos que cada instrumento musical possui possibilidades de ataque específicas, é o fato de que o piano, por ser um instrumento de cordas percutidas, está destinado à produção de sons descontínuos. Entretanto, a preocupação em criar o que podemos considerar como "ilusão da continuidade" é frequente entre compositores e instrumentistas. Tal artifício é o que possibilitaria aproximar o som deste instrumento ao da voz humana, permitindo que o piano "fale".

Este aspecto foi observado por Chopin e dentre suas preocupações didáticas figura o domínio do legato. O compositor insistia que essa articulação, que diz respeito à passagem ligada de uma nota à outra na execução de um fraseado, ocorresse com o mínimo de descontinuidade melódica.

Em descrição feita por um de seus alunos, temos que, segundo Chopin, "In legato playing, you should not merely join the notes, but bind then together, clinging to the keys - practising [...] obtaining every colour of sound just by modifying the weight of the fingers falling on the keys." (Shohet et al., 1988, p.32) 
Um segundo aspecto que podemos salientar é a variedade de articulações produzidas pela mão humana, a qual possuiria uma "voz" pessoal e cuja possibilidade de articular sons diferentes, ainda que dentro de suas limitações, deve ser considerada. Desta forma valoriza-se, por exemplo, a possibilidade de produzir ataques naturalmente diferentes de acordo com o dedo utilizado.

Enquanto alguns pianistas da época exercitavam seus dedos para que estes manifestassem maior igualdade ao realizar, por exemplo, uma escala, Chopin chamava atenção para a importância de articular cada som de modo diferente.

\footnotetext{
Personne ne remarquera l'inégalité du son dans une gamme très vite quand elle sera jouée également pour le temps — le but n'est pas de savoir jouer tout d'un son égal. Il me semble d'un mécanisme bien formé de savoir bien nuancer une belle qualité de son. On a longtemps agi contre nature [en] exerçant les doigts à donner de la force égale. Chaque doigt étant conformé différemment, il vaut mieux ne pas chercher à détruire le charme du toucher spécial de chaque doigt, mais au contraire le développer. (CHOPIN et al, 1993)
}

Assim, a diversidade constitutiva de cada dedo da mão, para cada pianista, é fonte de variedade sonora, não somente no que diz respeito à dinâmica, mas também ao timbre e à articulação.

\footnotetext{
Chaque doigt a de la force selon sa conformation. Le pouce, la plus grande, comme [étant] le plus gros, le plus court et le plus libre ; le cinquième comme [formant] l'autre extrémité de la main ; le 3eme comme milieu et point d'appui, le second aprè et puis le 4eme, le plus faible, celui qui est le siamois du trisième, lié à lui par un même ligament, et que l'on veut à toute force détacher du troisième [...]. (Chopin et al., 1993)
}

De fato, conforme Rosen (2000) já observou, a escolha de dedilhados idiossincráticos por Chopin possui reflexos na sonoridade de suas obras, criando um idioma particular. Dentre as tendências observadas, está a realização de uma delicada linha cromática somente com o $4^{\circ}$ e $5^{\circ}$ dedos, a saber, dedos cujo toque tende a ser mais leve, sendo que, em passagens mais difíceis, pode-se incluir o $3^{\circ}$ dedo. 
Outra tendência nas indicações do compositor é a execução de uma série de notas melódicas somente com o polegar, o que desacelera as notas, tornando-as expressivas.

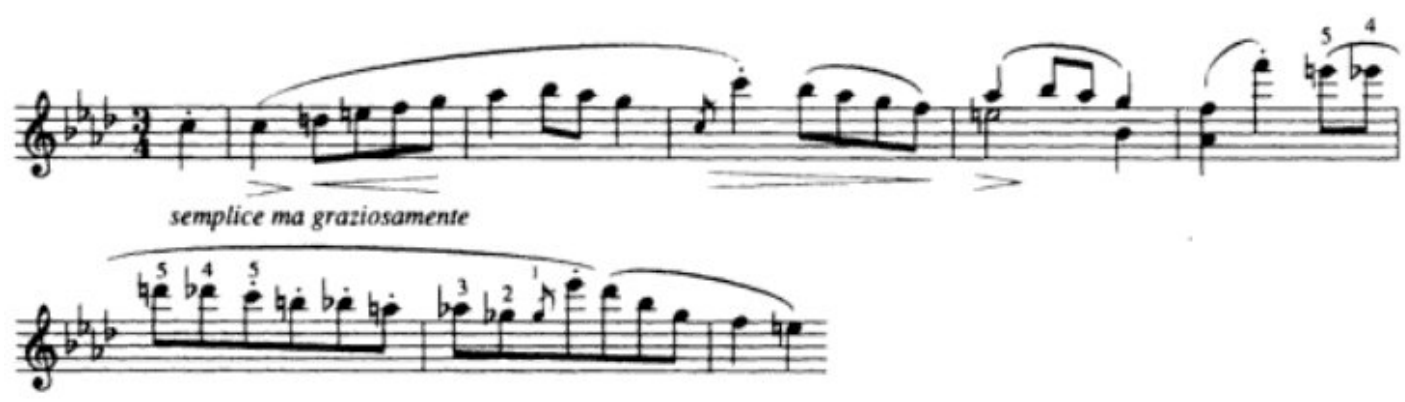

Figura 4.5: Compassos 1-8, III mov. Rondo -Vivace - Concerto para piano em fá menor de F. Chopin.

O cuidado na escolha de tais dedilhados, com vistas à articulação resultante entre as notas, demonstra a preocupação de Chopin com o aspecto timbrístico do fraseado.

Por outro lado, retomando a noção de continuidade e descontinuidade do som, não podemos deixar de observar a importância de tais movimentos na sua constituição e comportamento, ou ainda, na própria percepção que obtemos em relação à nota musical, se estendendo desta forma ao fraseado em que esta se insere.

Concluímos assim que, embora os constituintes harmônicos de uma nota justifiquem as regras de harmonia, a base do tratamento melódico, devido à sua dimensão linear ou dinâmica, parte de uma característica inerente ao som musical, ou seja, as continuidades e descontinuidades que o compõem.

Tais alternâncias geram um ritmo, e será esta a base para as considerações sobre o tempo que faremos mais adiante. 


\subsection{O ritmo}

1. Sucessão de tempos fortes e fracos que se alternam com intervalos regulares.

2. Movimento regular e periódico no curso de qualquer processo, cadência $<$ r. das ondas $><$ r. cardíaco $>$

3. Sequência harmônica de um fenômeno, uma atividade, uma obra etc., no espaço e/ou no tempo.

4. Sucessão de situações ou atividades que constituem um conjunto fluente e homogêneo no tempo, ainda que não se processem com regularidade.

5. Etimologia lat. rhythmus, 'movimento regular, cadência, ritmo', do gr. rhuthmós, oû. (Houaiss, 2009)

Embora na música seja comum nos atermos à primeira dentre as definições apresentadas, uma vez que sua estrutura notacional já conta com o auxílio das fórmulas de compasso, gostaríamos de enfatizar o significado etimológico, a fim de justificar a definição que utilizaremos mais adiante, mais próxima do ritmo tensivo.

A compreensão das origens da noção de ritmo, de acordo com o uso linguístico atual, remonta, segundo Benveniste (2005), ao significado que nos foi transmitido do grego, através do latim.

No texto "A noção de "ritmo" na sua expressão linguística" (idem, op. cit.) o autor observa que o termo rhuthmós tem por equivalente o termo forma. Entretanto diferentemente de uma forma fixa, realizada, o autor explica que:

rhuthmós, segundo os contextos em que aparece, designa a forma no instante em que é assumida por aquilo que é movediço, móvel, fluido, a forma daquilo que não tem consistência orgânica: convém ao pattern de um elemento fluido [...] é a forma improvisada, momentânea, modificável [...]. Pode-se compreender então que rhuthmós, significa literalmente "maneira particular de fluir". (Benveniste, 2005, p.368)

O uso deste termo estava assim profundamente relacionado a uma filosofia segundo a qual a representação das coisas móveis no universo poderiam ser determinadas como "fluições", daí este termo também estar relacionado com o verbo fluir. 
O desenvolvimento da acepção moderna de ritmo deve-se entretanto à Platão, já mencionado nos textos Filebo, Banquete e Leis. Segundo Benveniste, o filósofo grego define que "a harmonia é uma consonância, a consonância de um acorde [...] É de igual maneira que o ritmo resulta do rápido e do lento, primeiro opostos, depois concordes." (idem, op. cit., pág. 369) Assim, compreendemos o ritmo como uma "sequência ordenada de movimentos lentos e rápidos, assim como a "harmonia" resulta da alternância do agudo e do grave."

Ao retomar Benveniste (2005), percebemos ainda que "foi necessária uma longa reflexão sobre a estrutura das coisas, depois de uma teoria da medida aplicada às figuras da dança e às inflexões do canto, para reconhecer e denominar o princípio do movimento cadenciado" (idem, op. cit., pág. 370). O autor conclui o texto declarando que nada foi menos natural do que a elaboração deste conceito pelos pensadores dos quais herdamos seu significado atual.

A noção de ritmo também foi tratada por Messiaen (1996) como algo presente em todas as esferas da vida e das atividades humanas, assim como do mundo natural.

Já o ritmo tensivo, que abordamos no presente trabalho, deve seu desenvolvimento aos trabalhos de Claude Zilberberg. Este, além de valer-se da base linguística desse conceito, a qual remete à alternância de aberturas e fechamentos silábicos analisados por Saussure inspira-se também nos Cahiers de Paul Valéry.

Segundo Valéry (apud Zilberberg, 1996, p.4), o ritmo pode ser compreendido por meio da manifestação de uma periodicidade. Tal periodicidade instaura uma lei de sucessão que é reconhecida como algo que perceptivelmente possui um grau de aceleração variável. Assim, o ritmo captado por um sujeito depende do andamento ou das acelerações e desacelerações que este apresenta. 


\subsection{Tempo, forma e variação}

Como consequência do fato de que em outras artes tais como a escultura e a arquitetura, o ato criador supõe a ação sobre uma matéria que será modificada, podemos dizer também que a forma final será conservada por essa matéria.

No caso da música e da dança, Gisèle Brelet (1949b) busca estabelecer o que se denomina forma temporal. Embora em um primeiro momento esta expressão pareça contraditória, uma vez que o termo forma pressupõe algo já dado, já realizado, enquanto a questão temporal implica uma constante atualização, podemos recorrer aqui ao que se denomina "tempo intemporal" na qual o compositor traduz para a composição sua própria duração.

Esta duração, que é encarnada na obra musical, está além do tempo e é a própria essência deste pois reside na experiência temporal obtida pelo músico. Cabe à sonoridade o papel de recortar o tempo em porções, reorganizálas e reunificá-las. O tempo torna-se assim duração psicológica e forma temporal, subordinando uma à outra dentro do processo de criação musical.

Tal recorte é tratado por Claude Zilberberg em termos de funções temporais. No texto Relativité du rythme (1990), Zilberberg se dedica a construir um lugar do ritmo na teoria semiótica. O autor considera o tempo como um sincretismo por fusão, segundo a perspectiva glossemática. Segundo o autor:

Dois sincretismos são distinguidos: O "sincretismo por fusão", cuja manifestação corresponde a todos ou nenhum dos funtivos que entram nesse sincretismo, e o "sincretismo por implicação", cuja manifestação é idêntica a um ou vários funtivos que entram nesse sincretismo. Hjelmslev forja um exemplo emprestado à análise fonológica geral: se diante de uma consoante sonora, uma consoante surda se sonoriza, consideramos que uma consoante surda implica uma consoante sonora e que a consoante sonora é implicada por uma consoante surda. (Zilberberg, 2011, p.263).

Temos assim o tempo como uma função de natureza sincrética segundo o quadro abaixo: 


\begin{tabular}{|c|c|c|c|c|c|}
\hline Estrutura & \multicolumn{5}{|c|}{ Dimensões } \\
\hline \multirow{2}{*}{ Constantes } & F & \multicolumn{4}{|c|}{ TEMPO } \\
\hline & $\mathrm{f}$ & \multicolumn{2}{|c|}{ rapidez } & \multicolumn{2}{|c|}{ lentidão } \\
\hline \multirow{2}{*}{ Variáveis } & $\mathrm{F}$ & \multicolumn{2}{|c|}{$\begin{array}{l}\text { Tensão entre o sucessivo e } \\
\text { o simultâneo = duração }\end{array}$} & \multicolumn{2}{|c|}{$\begin{array}{l}\text { Tensão entre o sucessivo } \\
\text { e o simultâneo = ritmo }\end{array}$} \\
\hline & f & $\begin{array}{l}\text { Sucessivo } \\
\text { cronia }\end{array}$ & $\begin{array}{c}\text { Simultâneo } \\
\text { mnésia }\end{array}$ & $\begin{array}{c}\text { Fixo } \\
\text { cadencia? }\end{array}$ & $\begin{array}{l}\text { Livre } \\
?\end{array}$ \\
\hline
\end{tabular}

Além disso, o tempo integra quatro dimensões, sem se reduzir a uma delas: o tempo cronológico (d1) que determina o antes e o depois; o tempo rítmico (d2), que rege as durações; o tempo mnésico (d3) que compõe o presente, o passado e o futuro; e o tempo cinemático (d4) que diferencia rapidez e lentidão, acelerações e desacelerações:

\begin{tabular}{|c|c|c|c|}
\hline & & $\begin{array}{l}\text { DIMENSÕES } \\
\text { FIGURATIVAS }\end{array}$ & $\begin{array}{l}\text { EFEITOS DE } \\
\text { SENTIDO }\end{array}$ \\
\hline \multirow{2}{*}{ 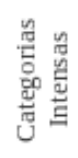 } & d1 & tempo cronológico & fluência \\
\hline & $\mathrm{d} 2$ & tempo rítmico & consistência \\
\hline \multirow{2}{*}{ 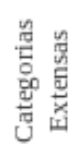 } & d3 & tempo mnésico & permanência \\
\hline & $\mathrm{d} 4$ & tempo cinemático & instância \\
\hline
\end{tabular}

Segundo Tatit (1998), a sobredeterminação dos tempos extensos sobre os tempos intensos, por meio de processos sintáxicos, permite extrair os conceitos de concentração e expansão, cuja inspiração reside nos movimentos de implosão e explosão da sílaba saussuriana.

Temos assim o movimento geral de expansão, que pode ocorrer tanto pelo aumento do muito, ou a extensão, quanto o aumento do pouco, pela concentração.

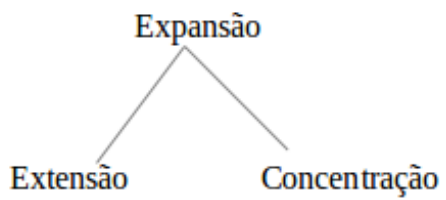

Assim, enquanto o tempo cronológico (d1) é representado por uma sucessi- 
vidade descontínua, ao dividir o presente em antes e depois, o tempo rítmico (d2) representa a instauração de uma lei por meio de uma identidade e neutraliza tal inexorabilidade do tempo. Já o tempo mnésico (D3) promove a expansão desta lei pelo discurso, gerando a previsibilidade, a simultaneidade e por consequência, a indivisão.

\begin{tabular}{|c|c|c|}
\hline & divisão & indivisão \\
\hline intenso & $\mathrm{d} 1$ & $\mathrm{~d} 2$ \\
\hline extenso & $\mathrm{D} 3$ & $\mathrm{D} 4$ \\
\hline
\end{tabular}

Com relação ao tempo cinemático (D4), temos que, a reiteração do conhecido, do rito, produz uma desaceleração no discurso da ordem da continuidade. Já a existência de desigualdades, promovem descontinuidades que impõem acelerações discursivas. Percebemos assim, que o tempo cinemático, responsável pelas acelerações e desacelerações discursivas, nos permite compreender o tempo semiótico em termos de continuidades e descontinuidades geradas pela interação dos demais parâmetros temporais.

Podemos compreender a origem das oscilações de andamento que vimos até aqui por meio de uma espécie de generalização das noções de consonância e dissonância, a qual que Gisèle Brelet desenvolve na passagem a seguir:

L'on sait combien les notions de consonance et de dissonance sont variables, et que le domaine du consonant ne cesse de s'étendre, car il ne saurait y avoir de bornes au pouvoir synthétique de l'esprit. Cependant vit au sein de la consonance et de la dissonance une valeur permanente, celle de leur contraste même, contraste essentiel à la durée musicale, indépendamment des valeurs concrètes par lesquelles ce contraste se réalise, et qui peuvent varier. Repos et mouvement, telles sont les valeurs permanentes cachées sous cette variabilité: peu importe ce que l'on appelle consonance ou dissonance, l'essentiel est que l'une personnifie le repos et l'achèvement, et l'autre l'élan et l'inquiétude, ces deux aspects antinomiques du temps que le temps musical se plaît à composer entre eux. (Brelet, 1949b, p.120 - grifo nosso)

Acrescentamos ainda, segundo Tatit (1998), que "as interações entre estas dimensões temporais reproduzem as tensões e distensões, as descontinuidades 
e continuidades, enfim, as oscilações a serem selecionadas no nível fórico, num plano de reflexão ao alcance da categorização descritiva." (p.21).

Desta forma estamos nos referindo à produção de tensões e distensões em um nível mais fundamental do que aquele atribuído aos sons, ou aos intervalos. Além disso, a disposição das notas de uma escala ou de uma melodia em um grupo de compassos com pulsação regular pode tanto seguir a direcionalidade sugerida por estes padrões tensivos quanto negá-los, conferindo à um intervalo um significado eufórico ou disfórico. 


\section{Capítulo 5}

\section{$\mathrm{O}$ andamento na interpretação musical}

\subsection{Cifras tensivas nas expressões de andamento}

Ao intérprete cabe, de forma mais ou menos restrita, conhecendo o estilo do compositor, imprimir, na interpretação, marcas de sua posição enquanto sujeito, retomando, pela partitura, uma imagem musical que só pode ser realmente percebida no momento da execução da obra. A notação musical é uma tentativa de realizar uma ponte entre a composição e a interpretação - Para tal ela se utiliza de diferentes símbolos que têm a função de definir a duração, altura e intensidade de um tom ${ }^{1}$.

Ao longo da história da música, para cada período e estilo, podemos encontrar um tipo de notação específico, o que é um reflexo não só do estilo musical utilizado mas também uma tentativa de exprimir de forma precisa a ideia original do compositor. Assim, observar as mudanças ocorridas na notação pode ser algo extremamente revelador do que se espera do intérprete em cada período.

De acordo com Hugo Riemann (1884), as indicações de tempo e andamento presentes em uma partitura constituem a agógica musical. Originalmente esta palavra se refere ao ato de conduzir, andar ou levar, estando a ideia de movimento sempre presente. Na música, indicações referentes a agógica podem ser encontradas tanto no início da partitura como em seu decorrer, por intermédio de palavras de origem italiana que adquirem acepção

\footnotetext{
${ }^{1} \mathrm{O}$ termo símbolo, aqui utilizado, diz respeito a um tipo de um grafismo convencionalizado cujo papel é denominar um tipo de relação ou operação a ser realizado no momento da interpretação.
} 
universal: Allegro, Andante, Lento, Accelerando, Stringendo etc ${ }^{2}$.

A partir do fim do período clássico o andamento também pode vir indicado como uma figura musical seguida de um número que representa a quantidade de batidas por minuto - bpm. Assim, em uma peça com a indicação semínima=120, temos que cada semínima deverá durar 60/120 = $0,5 \mathrm{~s}$. As expressões de andamento também podem ser interpretadas como indicações metronômicas em um intervalo de variação. Por exemplo, um allegro pode variar entre 120 e 168 batidas por minuto. Assim, o metrônomo tem por finalidade auxiliar o músico a obter um tempo padrão, ou seja, um pulso regular ao longo de toda uma composição ou de uma de suas seções. Mesmo levando-se em conta trechos com variações de andamento, como um tempo rubato, a indicação metronômica servirá para indicar o tempo em torno do qual as variações poderão ser realizadas.

A duração de uma interpretação é uma indicação geral relativa ao seu andamento. Por exemplo, uma gravação do Noturno que teve uma duração total de 5 minutos se comparada a outra interpretação deste mesmo Noturno com a duração total de 6 minutos indica que esta esteve em média $20 \%$ mais lenta do que a primeira.

Harnoncourt (2010) explica que tais indicações tiveram origem por volta do séc XVII quando os compositores escreviam nos prefácios de suas obras as indicações dos tempi desejados, sendo que, aos poucos, essas expressões foram sendo padronizadas em fórmulas e passaram a ser anotadas na primeira página da partitura.

Como exemplo de expressões temos "com um tempo um tanto quanto acelerado", "quanto mais rápido melhor" ou, em direção a uma precisão maior "os inícios das tocatas devem ser executadas devagar (adagio)", "depois devese mais ou menos acelerar (stretti)" etc. Assim, as expressões que utilizamos hoje, oriundas da linguagem coloquial italiana, foram pouco a pouco oficializadas e passaram a ser notadas acima do pentagrama, nas partituras.

\footnotetext{
${ }^{2}$ Não apenas a música, mas a cultura italiana, de um modo geral era dominante na cena européia durante os anos 1600 a 1750. Este foi o período no qual as marcas de expressão e de andamento foram introduzidas com base em seu desenvolvimento no sistema musical, assim o vocabulário internacional para estas expressões tornou-se italiano.
} 
Além disso, Harnoncourt (2010) também chama a atenção para o fato de que tais expressões

\begin{abstract}
só tem significado em relação com a notação, e nenhum valor absoluto na determinação do tempo; em muitos casos, é mais importante encará-las como indicação do caráter da obra do que como determinantes do tempo. Fundamentalmente, a primeira coisa a ser descoberta numa obra é exatamente seu caráter. Ele é, invariavelmente, triste ou alegre - com todas as formas intermediárias e ambiguidades possíveis. (Harnoncourt, 2010, p.68).
\end{abstract}

Assim, enquanto indicação de caráter, acreditamos ser possível construir uma ordenação extremamente precisa entre os termos que indicam tempos mais acelerados e menos acelerados, tomando como base apenas as indicações dadas pelas definições de cada palavra levando em conta sua cifra tensiva.

Segundo Harnoncourt (2010), na história da música, este princípio serviu de auxílio na escolha dos termos e expressões utilizadas para denominar tanto um movimento (Allegro, Andante, Presto) quanto os andamentos e suas variações ao longo da peça.

A noção de cifra tensiva foi introduzida na semiótica para descrever as categorias intensivas (andamento e tonicidade) e extensivas (temporalidade e espacialidade) presentes nas figuras passionais condensadas em palavras dos nossos discursos cotidianos. Os próprios dicionários incorporam de algum modo essas cifras na definição de seus verbetes.

Assim, se tomarmos um grupo de sinônimos quaisquer podemos colocar em evidência traços de diferenciação que se baseiem na duração implícita em sua definição.

Um exemplo é o grupo de palavras alegria/contentamento/felicidade/satisfação.

Segundo o dicionário Houaiss (2009):

Alegria 1 estado de viva satisfação, de vivo contentamento; regozijo, júbilo, prazer $<$ não cabia em si de tanta a. $>\mathbf{2}$ acontecimento feliz $<$ o nascimento do filho foi uma a. $>\mathbf{3}$ tudo o que alegra e contenta $<$ a neta era a a. de sua velhice $>\mathbf{4}$ festa, divertimento, folguedo. 
Contentamento 1 estado de contente, satisfação, gosto, alegria, júbilo

Felicidade 1 qualidade ou estado de feliz; estado de uma consciência plenamente satisfeita; satisfação, contentamento, bem-estar 2 boa fortuna; sorte $<$ para sua f., o ônibus atrasou, e ele pôde viajar $>\mathbf{3}$ bom êxito; acerto, sucesso $<$ f. na escolha de uma profissão $>$ felicidades s.f.pl. 4 votos de feliz êxito; congratulações f. eterna bem-aventurança, salvação eterna.

Satisfação 1 ato ou efeito de satisfazer (-se); contentamento, prazer advindo da realização do que se espera, do que se deseja.

Podemos perceber que essas palavras conservam alguma sinonímia entre si, pois todas se referem a um tipo de satisfação. No caso da alegria temos a expressão viva satisfação, o que sugere uma cifra mais acelerada. Já a palavra felicidade contém a cifra eterna, o que indica tratar-se de algo que se desenrola no tempo, pressupondo um andamento desacelerado.

Algo semelhante ocorre se opusermos as palavras ódio, raiva, ira e rancor. Todas mantêm alto grau de tonicidade combinado com variações de andamento: enquanto "raiva" pode decorrer de um tempo veloz ("ataque repentino de fúria"), "rancor" supõe um andamento mais desacelerado ("recordação tenaz e hostil"). Colocando sobre o eixo tensivo temos a imagem abaixo:

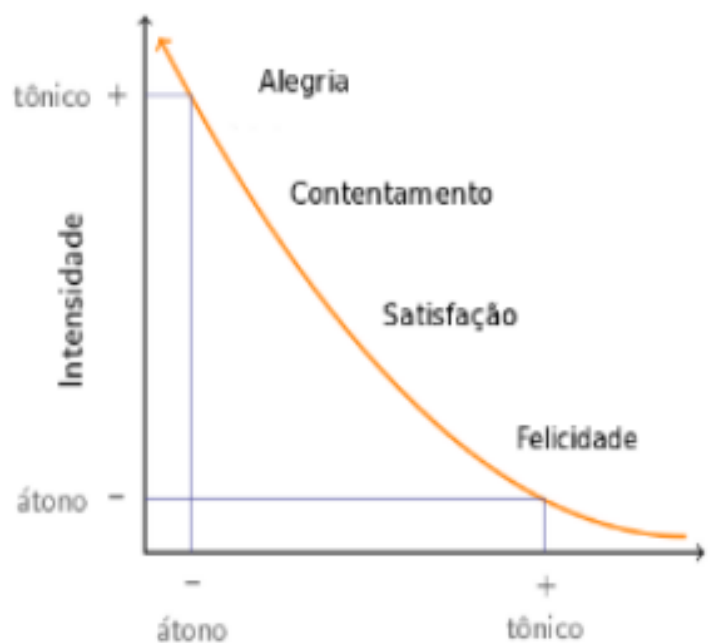

Extensidade

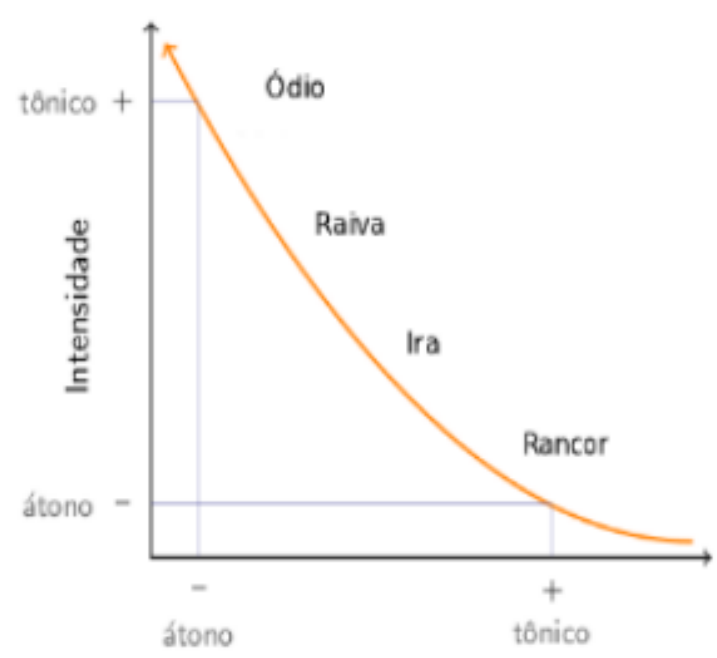

Extensidade 
Ao mesmo tempo, se levarmos em conta as expressões mais comumente utilizadas na música, temos palavras derivadas do italiano como Vivo, Allegro, Presto para indicar um andamento rápido, e Largo, Andante, Adagio indicando andamento lento. São todas cifras tensivas de andamento.

Assim, obtemos as seguintes marcações aproximadas do metrônomo:

\begin{tabular}{|c|c|c|}
\hline Andamento & bpm & Definição musical \\
\hline Gravíssimo & $<40$ & Extremamente lento \\
\hline Grave & 40 & Vagaroso e solene \\
\hline Larghissimo & $40-60$ & Muito largo e severo \\
\hline Largo & $40-60$ & Largo e severo \\
\hline Larghetto & $60-66$ & Mais ligeiro que o Largo \\
\hline Lento & $60-66$ & Lento \\
\hline Adágio & $66-76$ & Vagarosamente \\
\hline Adagietto & $66-76$ & Pouco mais rápido que Adagio \\
\hline Andante & $76-108$ & Velocidade do andar humano \\
\hline Andantino & $84-112$ & Mais ligeiro que o Andante \\
\hline Moderato & $108-120$ & Moderadamente, nem rápido, nem lento \\
\hline Allegretto & $112-120$ & Não tão ligeiro como o Allegro \\
\hline Allegro & $120-168$ & \\
\hline Vivace & $152-168$ & Ligeiro \\
\hline Vivacíssimo & $168-180$ & Mais rápido e vivo que o vivace \\
\hline Presto & $168-200$ & Extremamente rápido \\
\hline Prestíssimo & $200-208$ & Mais rápido do que o Presto \\
\hline
\end{tabular}

Tomando estes termos como base, é possível fazer análises mais detalhadas das variações de andamento tais como acelerações e ralentandos presentes no decorrer de uma peça.

Por exemplo, no Noturno op.23 n.2 de Chopin temos a indicação Lento sostenuto. Segundo o dicionário Groove de música o termo sostenuto, de origem italiana, significa sustentado. Assim, esta expressão indica que as notas devem ser mantidas, ou sustentadas em sua duração completa. Já no caso de uma passagem lento sostenuto, além de lento, o andamento deve ser sustentado ou uniforme.

Temos dessa forma um comportamento semelhante a um instrumento co-repetidor, que acompanha ou "sustenta" o canto durante a execução de um recitativo ou uma ária, devendo-se dosar o acompanhamento segundo as 
variações rítmicas que o cantor cria no momento da recitação, pois, ao mesmo tempo que fornece a sustentação harmônica, o baixo mantém um pulso de base sobre o qual as variações realizadas pela voz ganharão maior relevo.

O mesmo princípio segue a interpretação de um Noturno. Neste, a mão esquerda deve passar a impressão de algo uniforme e sustentado, mais próximo ao tempo metronômico, para que as linhas melódicas pertencentes à voz superior sejam destacadas.

\subsection{O tempo rubato}

A escolha do tempo rubato justifica-se pelo seu uso em algumas composições de Frédèric Chopin. Apesar disso não se pode dizer que tal expressão não fosse conhecida pelos músicos de períodos anteriores.

Assim, uma definição precisa dessa expressão teria que levar em conta suas variações em termos históricos, uma vez que cada período musical possui caraterísticas e estilos próprios e passou a interpretá-la de modo diferente.

Literalmente esta expressão significa "tempo roubado" ou retirado de um grupo de notas ou frase musical com a condição de ser compensado em um segundo grupo, de forma que o tempo total do período ou frase musical não se altere. A ideia é a de que ocorra uma alteração no andamento, mediante uma aceleração ou desaceleração, mas que esta seja compensada posteriormente.

É comum tempo rubato ser confundido com as expressões a piacere (à vontade), ad libitum (com liberdade) ou a capriccio (ao capricho), nas quais o intérprete tem total liberdade para acelerar ou ralentar o andamento. Todas estas expressões têm em comum o fato de serem opostas à expressão tempo giusto (tempo justo), com o sentido de tempo metronômico.

De fato, embora as expressões tempo rubato e tempo giusto tenham significados interpretativos opostos (respectivamente deslocamento e constância temporal), a correta interpretação de ambos os termos representa uma dificuldade e, ao mesmo tempo, um ponto de diferenciação no universo da interpretação musical.

Leopold Mozart, em seu A Treatise on the Fundamental Principles of 
Violin Playing (1985) declara que:

\begin{abstract}
One must also be able to divine from the piece itself whether it requires a slow or a somewhat quicker speed. It is true that at the beginning of every piece special words are written which are designed to characterize it, such as "Allegro" (merry), "Adagio" (slow) and so on. But both slow and quick have their degrees. ...So one has to deduce it (the tempo) from the piece itself [...]. Every melodious piece has at least one phrase from which one can recognize quite surely what sort of speed the piece demands. Often, if other points be carefully observed, the phrase is forced into its natural speed ${ }^{3}$. (Badura-Skoda \& Badura-Skoda, 2010, p.71).
\end{abstract}

O fato de Chopin ser um dos compositores que inauguraram o período romântico na música, trazendo consigo muitas heranças do período clássico (principalmente de Mozart), dificulta ainda mais o nosso trabalho de determinar uma forma de interpretação que corresponda ao seu rubato. De modo geral, sabemos que as variações provocadas no andamento devam ser coerentes em relação à estrutura geral da composição e suas necessidades expressivas.

Mozart declara [...] but now he sees and hears that I am the better player, that I do not make grimaces, and yet play with such good results out of his pianofortes. Everyone is amazed that I always keep strict time. (Badura-Skoda \& Badura-Skoda, 2010, p.84 - grifo nosso). Entretanto, observamos que, nas execuções de Mozart, tal ajustamento está presente, sendo um componente indispensável:

\begin{abstract}
This makes the melody; therefore time is the soul of music. It does not only animate the same, but retains all the components parts in their proper order. Time decides the moment when the various notes must be played, and is often what is lacking in many many who have otherwise advanced fairly far in music and have a good opinion of themselves. This defect is the result of their having neglected time in the first instance. (Mozart, 1985, 30 - grifo nosso).
\end{abstract}

\footnotetext{
${ }^{3}$ É preciso deduzir o andamento a partir da própria peça, e é por meio dessa habilidade que o verdadeiro valor de um músico pode ser plenamente reconhecido. Cada peça melodiosa tem ao menos uma frase a partir da qual é possível reconhecer com absoluta certeza que tipo de velocidade a peça exige. Com frequência, se os demais pontos forem cuidadosamente observados, a frase forçosamente se encaixará na sua velocidade natural.
} 
Com relação à variação temporal, Badura-Skoda expõe que "Only those who are able to play in time should allow themselves to make conscious deviations in tempo known as agogics and rubatos" (Badura-Skoda \& Badura-Skoda, 2010, p.85).

\subsection{Duas análises}

Valendo-nos dessas observações, vamos comparar a seguir duas interpretações do Noturno op.15 No.3 de Chopin. O modo de comparação utilizado terá por base as waveforms de cada interpretação. Uma waveform é um tipo de visualização criada a partir de um arquivo de áudio. Neste tipo de representação, observamos o tempo sinalizado no eixo horizontal e as frequências e intensidades no eixo vertical.

Na primeira waveform, temos uma análise da leitura feita pelo software Timidity, o qual converte um arquivo de áudio no formato MIDI (Musical Instrument Digital Interface) em arquivo WAVE (abreviação para waveform audio format)

Por meio das marcações, podemos perceber que o tempo se mantém constante, com todos os compassos seguindo a mesma duração. Nesse caso, a indicação metrônomica no início da peça é seguida à risca, sem considerar sua finalidade interpretativa.

Tal constância excessiva resulta em duas consequências principais. A primeira é que a total ausência de variações, assim como o seu excesso, provoca a dispersão do sentido, aqui, no caso gerado pela predominância do tempo cronológico, responsável pelas sucessões ininterruptas. Trata-se de uma fluência sem consistência.

A segunda é que, não havendo sobredeterminação dos tempos extensos sobre os tempos intensos, não observamos os efeitos de alternância entre concentração e extensão responsáveis pela expansão discursiva. 


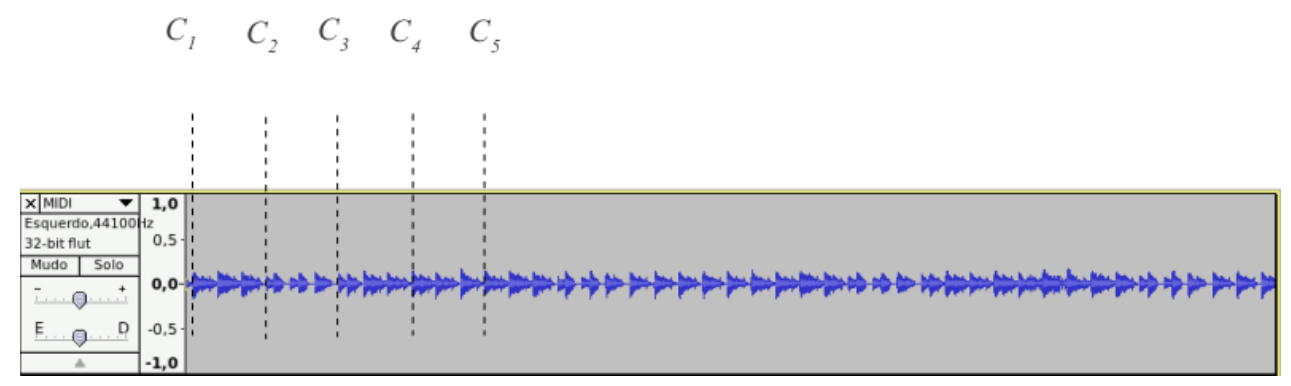

Figura 5.1: Waveform Noturno op.15 n.3 - MIDI.

Na comparação feita com a interpretação de Guiomar Novaes, percebemos que, embora ela tenha seguido em alguns momentos a indicação metronômica, em outros, surgem tanto ampliações quanto reduções da duração total do compasso, tornando possível a tradução da indicação languido e rubato, expressa no início da partitura e, portanto, válida para todo o trecho observado.

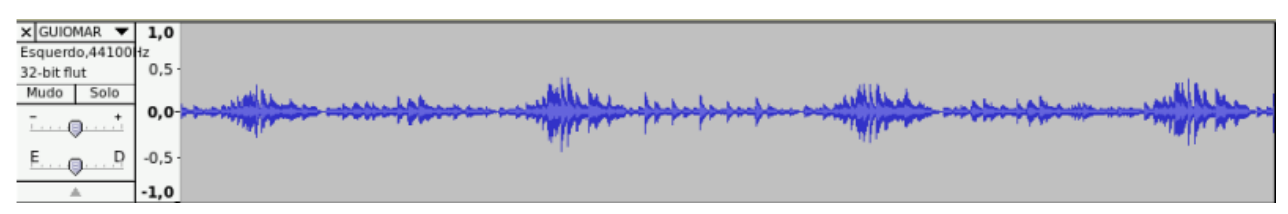

Figura 5.2: Waveform Noturno op.15 n.3 - Guiomar Novaes.

Além disso, com relação à forma, o Noturno op.15 n.3 pode ser dividido em três partes das quais tomamos para comparação as duas primeiras. $\mathrm{Na}$ primeira parte, temos como indicação de andamento languido e rubato, já na segunda temos indicado religioso.

Estas duas expressões podem ser consideradas opostas tendo em vista que no tempo rubato é permitida maior variação com relação ao tempo metronômico, enquanto a indicação religioso pode ser entendida quase como uma ausência de variações, como um movimento que se deixa levar pela pulsação dada.

É possível perceber isso observando a waveform obtida a partir dos oito primeiros compassos de cada parte. Desta forma, se, na primeira parte, percebemos que os compassos variam bastante em sua duração, na segunda, eles são mais regulares, havendo maior previsibilidade. 


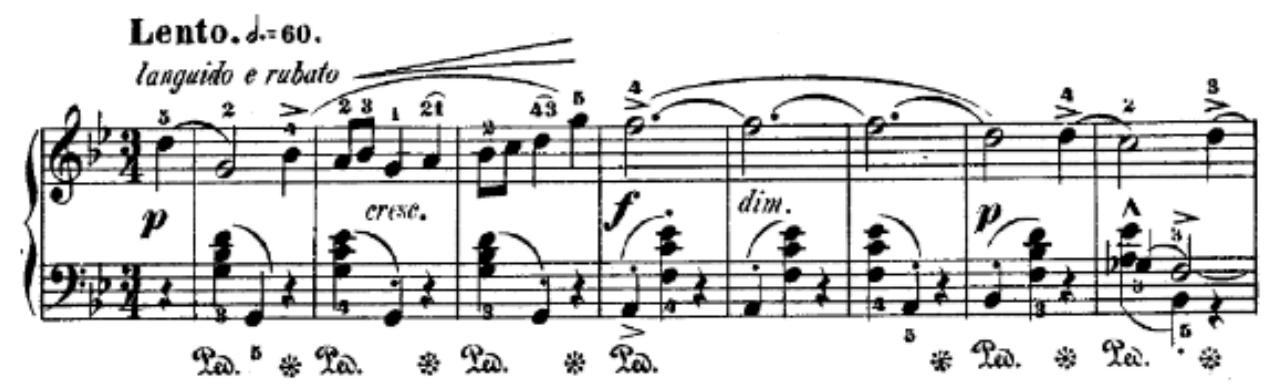

Figura 5.3: Noturno op.15 n.3 - compassos 1-8.

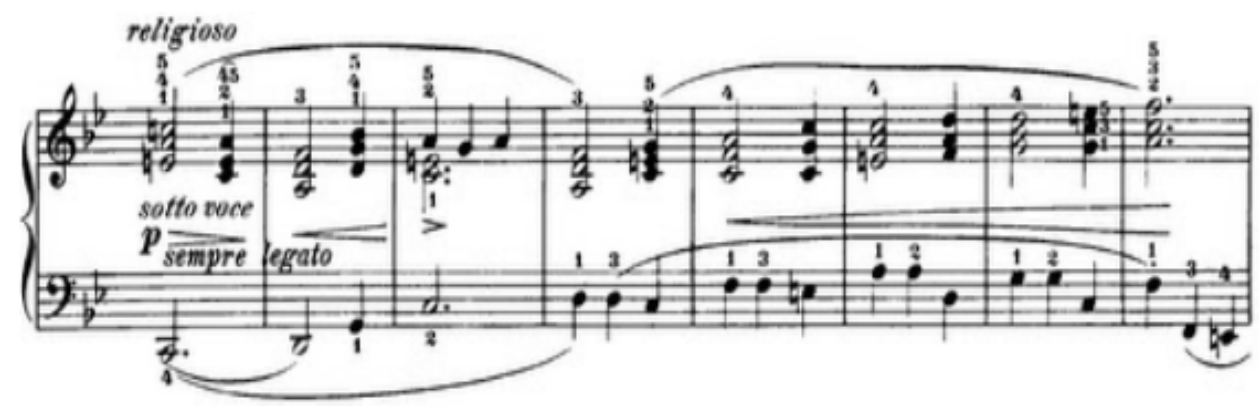

Figura 5.4: Noturno op.15 n.3 - compassos 89-96.

De acordo com a primeira imagem, podemos constatar um acelerando nos três primeiros compassos, uma estabilização nos compassos 5 e 6 e um ralentando nos compassos 6 e 7; assim, há uma espécie de compensação da velocidade, exigida pelo andamento rubato, e realizada por meio de intervalos.

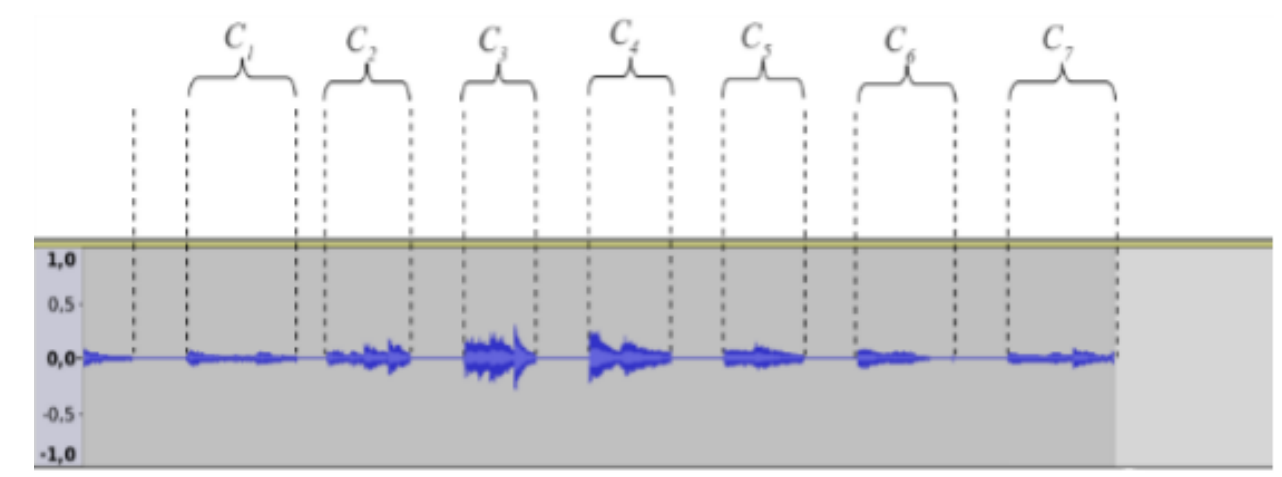

Figura 5.5: Waveform Noturno op.15 n.3 - compassos 1-8, Guiomar Novaes.

Já na segunda imagem, temos os primeiros compassos da segunda parte da obra no qual a indicação de andamento é religioso; aqui a pianista segue a indicação metronômica de forma que todos os compassos tenham a mesma 
duração.

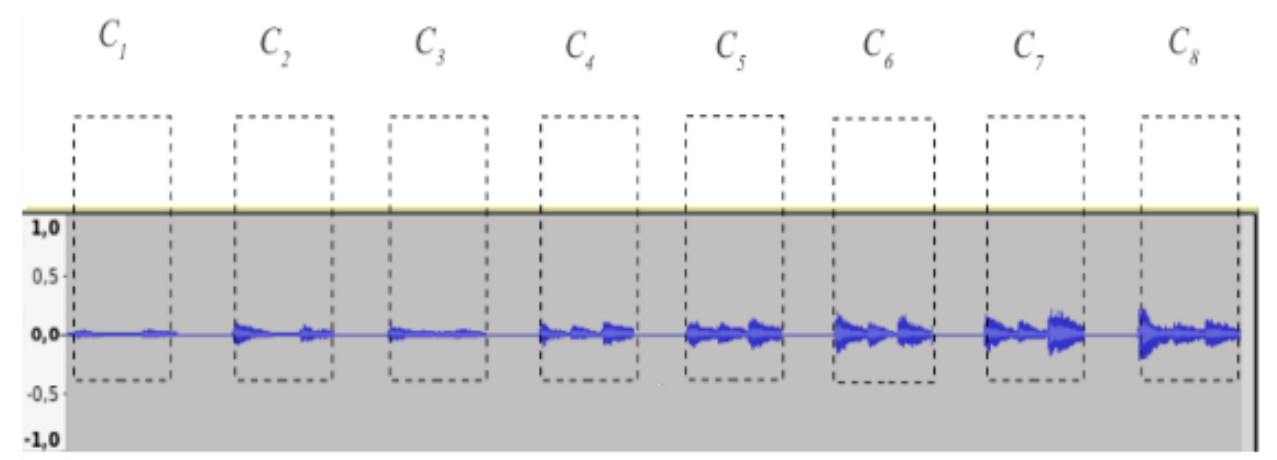

Figura 5.6: Waveform Noturno op.15 n.3 - compassos 89-96, Guiomar Novaes.

Por meio da escuta, podemos também perceber que a cifra tensiva, sugerida pela indicação expressiva religioso, de fato é criada pela pianista e pode-se dizer que além das alterações de dinâmica (sotto voce) esta variação de andamento contribui para a sua construção.

Desse modo, embora obedeça à pulsação ditada pelo tempo metronômico, concluímos que o midi não é capaz de provocar um ajuste entre os diferentes tempos que constituem a base da linguagem musical. É justamente esta harmonização, ou sobremodalização temporal, que confere à obra uma intencionalidade e torna possível a construção de um sentido interpretativo pela pianista. 


\section{Capítulo 6}

\section{Quatro análises}

\subsection{O Noturno Op.23 n.2}

Nossa intenção com as análises que seguem é bem mais compreender a possibilidade de aplicação de alguns conceitos desenvolvidos no trabalho, tomando como base um repertório razoavelmente conhecido e acessível, do que a realização de uma análise exaustiva.

A escolha dos Noturnos de Chopin deve-se a dois motivos principais. O primeiro é a presença do tempo rubato, que pode ser literalmente anotado pelo autor ou permanecer implícito ao material sonoro e caráter geral da peça.

O segundo motivo deve-se ao fato de que tais melodias, embora inspiradas no canto, seguem uma entonação tipicamente "pianística". De fato, Chopin é normalmente considerado o poeta do piano, tendo dedicado quase a totalidade de suas composições a esse instrumento. Já os Noturnos ocupam um lugar à parte na obra do compositor.

Assim como Bach, que compôs peças essencialmente didáticas como as Invenções a duas e três vozes, tendo como finalidade ensinar o músico a cantar as diferentes vozes com independência, Chopin utilizava os Noturnos para ensinar seus alunos a cantar ao piano, quando não lhes recomendava também que fizessem aulas complementares de canto.

Entretanto, trata-se de entoações de natureza diferente. Uma melodia de Chopin, embora inspirada na voz humana, principalmente no canto ope- 
rístico, dificilmente soa natural ao canto. São melodias para serem tocadas no piano e parecem se encaixar perfeitamente neste instrumento, explorando todas as suas potencialidades sonoras.

Limitaremo-nos assim a explorar este aspecto da obra de Chopin, tendo como base para tal as alterações de velocidade, a escolha do andamento e as variações de ritmo presentes em interpretações diferentes do Noturno op.23 n.2 em ré bemol maior.

Nosso objetivo aqui é compreender como cada intérprete "molda o tempo". Segundo Gerling (2008):

\footnotetext{
Quando músicos se reúnem para tocar em conjunto, a primeira pergunta, geralmente, é: Qual o seu andamento para esta peça? Esta pergunta evidencia a importância que atribuímos ao tempo na execução musical. O tempo é a tela do músico. É o nosso espaço. Podemos mudar de maneira dramática o caráter de uma ideia musical ao mudarmos seu andamento e, consequentemente, o segmento temporal que ocupa. (p.10).
}

É como se, na partitura, a obra estivesse condensada e, por meio da interpretação, ela fosse expandida, para mais ou para menos, segundo o trecho e a dosagem realizada pelo intérprete, de modo a adquirir uma "forma" específica.

Para a nossa análise selecionamos quatro registros do Noturno. Dois são realizados pelo pianista Maurizio Pollini, um deles durante um recital em vídeo (Registro em vídeo - rv) e o outro em formato de áudio-CD (Registro em áudio - ra), e os outros dois são gravações comerciais realizadas pelos pianistas Arthur Rubinstein (r) e Luiz Castro (c).

Gostaríamos de conduzir nossa análise a partir de quatro parâmetros principais. Inicialmente, ao considerar a indicação Lento rubato, procuramos compreender como cada intérprete realizou as variações de velocidade que a expressão subentende. Um segundo parâmetro foi o andamento geral, mais lento ou mais acelerado, adotado pelo intérprete e o reflexo dessa escolha na forma e no caráter geral da interpretação.

Finalmente, consideramos interessante observar o modo como ocorrem as micro acelerações/desacelerações nas passagens entre blocos mais lentos ou 
mais rápidos. Percebemos assim que tais passagens não servem apenas para ajustar as velocidades, mas que tal ajuste pode ser feito de formas diferentes segundo o estilo do intérprete.

Além disso, o fato de, na nossa seleção, constar duas execuções de um mesmo intérprete, objetivou compreender a seguinte proposição, feita pelo próprio pianista:

My interpretation, I have to say, always changes, but it changes very gradually, because even the first interpretation was the fruit of a lot of thinking etc. So it has already established a certain line. But the line can enlarge itself with time, a new perspective can join it, and so there is a development. For Chopin it seems to me that I play with rather more freedom and rubato than I did in my first years. If I listen to my first recordings made in the early 1970s I still like it, there are some studies I like very much, but it is very strict in the timing. But now I think I play Chopin in a more free way. I still have a certain idea that perhaps too much rubato perhaps doesn't add very much to the best image of this composer that we can have. A certain reserve in the rubato is absolutely necessary. It is said that it existed in Chopin's playing so it's absolutely necessary - the rubato. But the rubato extended to the limit could be not of great help to the understanding of this music as great music.

It's not a matter of how much rubato, it's a question of the quality of the rubato. Some pianists have more freedom, some have more restraint. It's a question of how they do it. (POLLINI, Maurizio Pollini Hong Kong interview by RTHK - The Works, 14 April 2009 - grifo nosso)

No Noturno op.23 n.2, apesar da indicação Lento sostenuto, ou lento sustentado, temos uma sugestão metronômica de semínima pontuada $=50$, indicando já de saída um andamento bastante acelerado, que a princípio vai de encontro ao caráter mais lírico da primeira frase da peça, o que sugere um andamento lento. Além disso, no compasso 52, trecho já acelerado, a necessidade de seguir um andamento rápido implica tocar aproximadamente 22 notas por segundo.

Um outro aspecto é a presença do ostinato, que constitui um padrão rítmico e/ou melódico repetido obstinadamente, com pouca ou nenhuma variação, de modo a reconhecermos a presença de uma identidade em tais re- 
petições. Assim, cria-se uma espécie de ritual, no sentido de que se instaura a espera por meio de uma "progressão rítmica que reduz consideravelmente a possibilidade de intervenção abrupta da surpresa." (Tatit, 1998, p.54). Segundo Wisnik:

Se você tem um barulho percutido qualquer e ele começa a se repetir e a mostrar uma certa periodicidade, abre-se um horizonte de expectativa e virtualidade de uma ordem subjacente ao pulso sonoro em suas regularidades e irregularidades. Do mesmo modo, se você está falando e de repente produz e sustenta um som de altura definida, remete a fala para um outro lugar, o paradigma das alturas contínuas, não codificado pela língua, com toda a estranheza que isso implica (e pode-se saltar então do patamar da fala para o canto, ou habitar o espaço intercalar entre ambos). (Wisnik, 1989, p.33).

Assim, estabelecem-se as condições para uma sobreposição de tempos, pela contraposição de uma melodia com o baixo em ostinato, gerando por meio das igualdades e desigualdade as acelerações e desacelerações características do tempo rubato.

Quanto mais desigualdades mais aceleração e dispersão do sentido. O excesso de continuidade, por outro lado, pode desacelerar demais o discurso - cuja existência afinal decorre de uma falta original, de uma fratura do contínuo - transformando-o em algo quase sem metas, sem direcionalidade, em uma palavra, sem sentido. (Tatit, 1998, p.22).

Enquanto o ostinato é responsável pelas continuidades, tanto rítmica quanto timbrística, além de manter-se em uma tessitura mais fechada, a linha melódica será responsável pelas descontinuidades, por meio da variedade timbrística e amplitude de registro.

Assim, embora não tenhamos necessariamente uma aceleração seguida por sua compensação, como no exemplo de fraseado que apontamos no op.15 n.3, podemos observar as alternâncias entre concentração e expansão que são características do rubato: 
rítmico. Sob o modo da aceleração, o tempo cinemático produz as descontinuidades que omitem etapas do discurso, abreviam as durações, provocam síncopes, metáforas, precipitações e colaboram com o processo de ampla concentração (no sentido silábico).

Sob o regime da desaceleração, o andamento recobra as continuidades e, com elas, a duração, o percurso, as etapas intermediárias, as gradações, as hipérboles, o processo metonímico, fazendo com que o ritmo recupere a extensão (abertura silábica). (idem, op. cit.)

Compararemos a seguir as quatro gravações em quatro momentos diferentes a fim de compreender como ocorre o ajuste entre o ritmo e o andamento.

De início, observamos que, quanto ao tempo metronômico, ou pulso subjacente às variações temos que Pollini ra com semínima pontuada $=40$, Pollini rv $=44$, Castro $=33$ e Rubinstein $=40$. Observamos que tal marcação nos diz muito pouco sobre o real comportamento do andamento, uma vez que o tempo total varia de modo não proporcional:

\begin{tabular}{|c|c|c|}
\hline & Pulso aproximado & Duração total \\
\hline Pollini ra & 40 & $4: 15$ \\
\hline Pollini rv & 44 & $4: 54$ \\
\hline Castro & 33 & $6: 23$ \\
\hline Rubinstein & 40 & $6: 08$ \\
\hline
\end{tabular}

Isso ocorre pela grande variação no uso do rubato. Assim embora tenhamos Pollini ra e Rubinstein com o mesmo valor para o pulso, Pollini ra apresenta menos variações dentro deste pulso, já acelerado, o que permite uma duração total menor. Já Rubinstein apresenta grandes inflexões de tempo, com máximos e mínimos expandidos de acordo com o fraseado, o que aumenta a duração total da peça.

Um outro fator que observamos e que nos permite obter uma visão geral da interpretação é o fato de ocorrer em Pollini rv e Rubinstein uma desaceleração proporcionalmente mais acentuada em relação aos dois trechos, rápido e lento em que esta desaceleração se intercala. sugerindo a necessidade de um ajuste maior entre o andamento da obra e o andamento utilizado pelo intérprete. Como exemplo, temos os compassos 25 e 45, cuja desaceleração 
antecede a volta ao motivo principal.

\subsection{Hemíolas, polirritmia e fatores de coesão}

Na música, o andamento se refere à pulsação básica subjacente a uma composição musical. Assim, o tempo musical pode ser visto como um sinônimo da expressão de andamento.

O que nos interessa mais diretamente neste trabalho é o modo como, seguindo estes mesmos princípios, um intérprete consegue criar duas camadas de "tempos diferentes" em uma mesma peça, tal como um Noturno, a qual segue o princípio de melodia acompanhada. No caso de Chopin, entretanto, é clara a intenção de que tais andamentos sejam de fato tão independentes quanto possível, como veremos na análise das marcações realizadas na partitura.

No Noturno op.15 n.3, temos uma oposição entre os andamentos de suas seções: lento e rubato, na primeira e religioso, na segunda. Esta oposição não se define tanto pelo grau de velocidade (ambas são de andamento lento), mas sim pela maior presença de variação (vivo vs. lento) na primeira parte, quando comparada ao andamento mais próximo ao tempo metronômico, ou mais estável, na segunda parte.
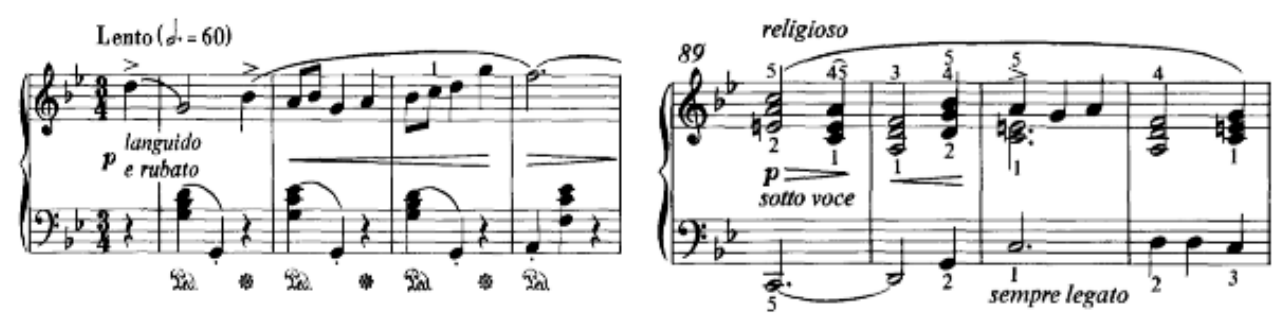

Figura 6.1: Noturno op.15 n.3 - compassos 1-4 e 89-92.

Realizamos aqui uma oposição entre as partes da peça, ressaltando, entretanto, que, mais do que uma simples oposição entre seções, estamos lidando com os intervalos e variações que as compõem, cujo comportamento lhe confere esse caráter geral.

Já no caso do Noturno op.23 n.2, temos uma situação semelhante a um modo de concomitância: 
Por modo de concomitância, entendemos, de um lado, certa classe de objetosacontecimentos, ou ainda, desafios decorrentes de flagrantes desigualdades de andamento e, de outro, o tratamento que os sujeitos, tendo em vista os recursos semióticos disponíveis, aplicam às diferenças intempestivas de andamentos que os solicitam. (Zilberberg, 2011, p.103).

Tal comportamento, caso o restrinjamos ao aspecto do andamento, pode ser associado à presença das hemíolas na música.

A hemíola surgiu sobre a base da notação musical do final do período medieval, como um tipo de ambiguidade originada da métrica de seis pulsos que pode dividir-se em três grupos de duas notas ou em dois grupos de três. Durante o período barroco, a hemíola foi muito utilizada na composição de danças, como por exemplo as courantes, e continuou presente ao longo do período clássico e século XIX. O uso da hemíola por Chopin, com o sentido de criar um efeito de rubato, foi pesquisado pelo físico Douglas Hofstadter. (Hofstadter, 1996, p.179).

Esse tipo de efeito serviu de inspiração para compositores como Ligeti ao compor obras polirrítmicas. Temos como um de seus exemplo de inspiração polirrítmica a 4a Balada de Chopin, na qual ocorre uma sobreposição de camadas rítmicas, algumas não tendo mais relação com o compasso original de 6/8. Assim, sobre uma pulsação, Chopin cria uma segunda e dentro dela privilegia algumas durações reunidas.

Neste trecho, extraído da 4a Balada (compassos 175-176), temos tercinas ou hemíolas, na mão direita, competindo com os grupos de seis notas tocadas pela mão esquerda. Ao mesmo tempo, a melodia superior executa um fraseado que cria um outro padrão sobreposto às tercinas, combinando-as em grupos de quatro notas. 


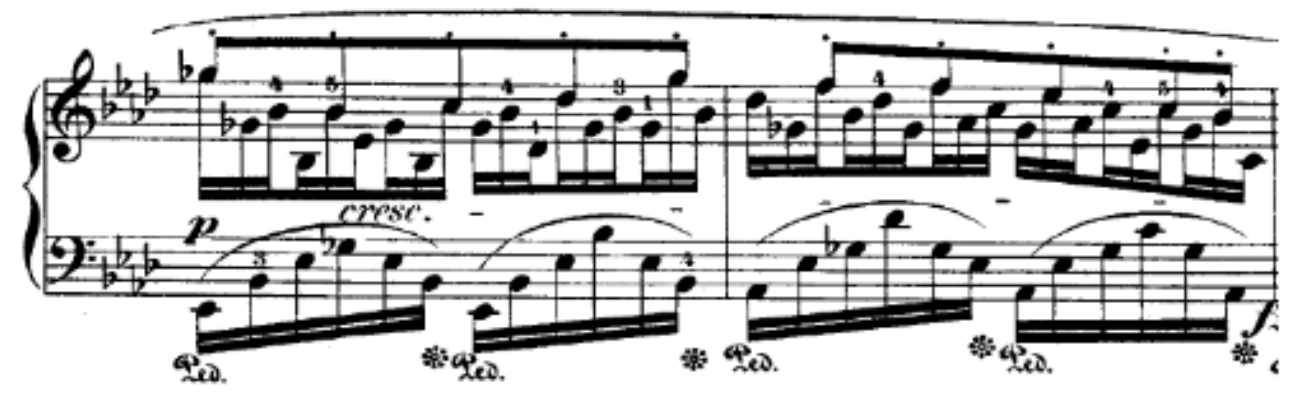

Figura 6.2: Balada op.52, F. Chopin - compassos 175-176.

Abaixo temos o mesmo tipo de raciocínio polirrítmico agora extraído do Noturno que escolhemos para análise:

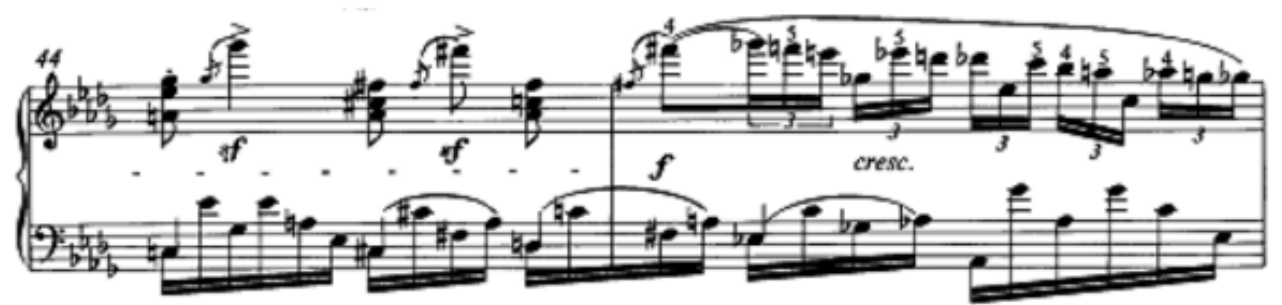

Figura 6.3: Noturno op.23 n.2, F. Chopin - compassos 44-45.

Aqui Chopin cria o mesmo efeito ao deslocar os acentos do compasso original, criando um compasso dentro de outro com dois andamentos simultâneos. Mais tarde, em algumas obras de Ligeti, a barra de compasso utilizada na notação musical convencional será mantida apenas como um auxílio para a leitura da partitura, não correspondendo mais a sensação de pulso imaginada pelo compositor.

Retomando o caso específico do aspecto temporal do op.23 n.2 de Chopin, compreendemos que, ao executar determinados trechos do Noturno em questão, o instrumentista procurará obter simultaneamente dois timbres diferentes: um com menos descontinuidades, responsável pelo acompanhamento, e outro que seguirá as inflexões da melodia.

Podemos observar também a presença de duas tessituras diferentes, uma mais estabilizada, limitada à região média do piano numa extensão de duas oitavas, e a voz superior, com o dobro dessa extensão, e portanto com mais variações e descontinuidades. Além disso, os efeitos de intensidade e modos de ataque presentes na linha melódica superior são extremamente va- 
riados. Todos esses fatores contribuirão para a percepção de um andamento mais rubato na voz superior, em contraste com o acompanhamento.

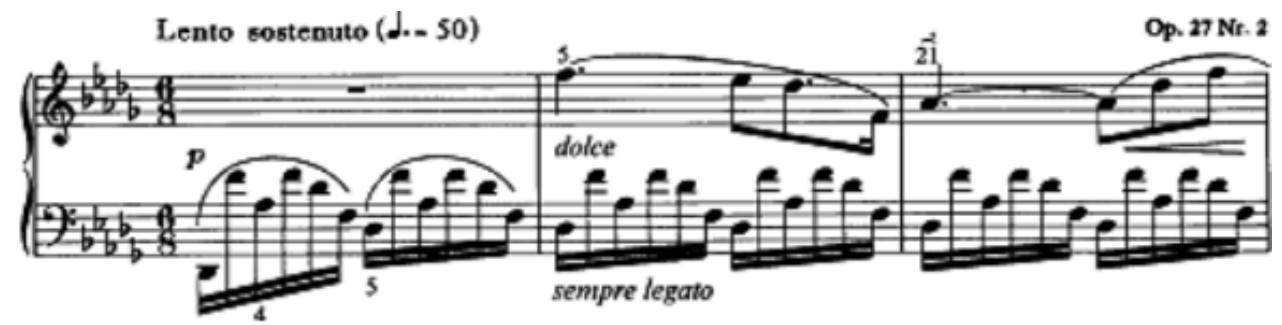

Figura 6.4: Noturno op.23 n.2, F. Chopin - compassos 1-3.

Assim, obtemos um tipo de polifonia entre os andamentos da melodia e do acompanhamento. Neste caso, o sentido geral da peça dependerá de como o intérprete conduz esses dois andamentos distintos.

A respeito deste Noturno, Charles Rosen (2000) observa que:

The importance of the heterophonic texture for Chopin - the single melodic line simultaneously displayed in different rythms in two voices or more - is that is preserves the supremacy of the Italian-style melody while allowing a richly interesting polyphonic development. It also allows the accompaniment to become melody at any moment, and maintains the implicit existence of melody in subsidiary layers. (p.350).

De fato, o autor ainda observa que a melodia do motivo melódico exposto no compasso 2, que retornará em forma de dueto no compasso 19, já se encontra "escondida" no primeiro compasso de abertura realizado pelo acompanhamento.

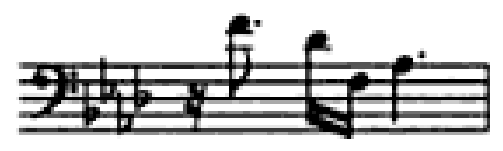

Figura 6.5: Noturno op.23 n.2, F. Chopin - Motivo do baixo.

Ao mesmo tempo, Rosen (2000) chama a atenção para o fato de que esse tipo de contraponto entre a voz principal e o acompanhamento, típico de Chopin, representa uma dificuldade para a interpretação. 
Caso se execute o trecho destacando a existência do tema no baixo, a interpretação corre o risco de soar pedante, por outro lado, caso se ignore totalmente esta relação, estabelecida pelo próprio compositor, o resultado final pode parecer mecânico, perdendo sua organicidade. O autor conclui então que talvez a melhor solução seja executar tal motivo com uma "semiconsciência" de sua existência.

De fato, se pensarmos no fenômeno da temporalidade, temos que o tempo cronológico está sempre presente, assim como as demais modalidades. Entretanto, sua percepção deve ser dosada pelo instrumentista a fim de criar efeitos de continuidade e descontinuidade.

No caso de se destacar o tema implícito no baixo, corre-se o risco de gerar uma descontinuidade desnecessária, que concorrerá com as descontinuidades da melodia, resultando em um efeito de ruído. Por outro lado, o efeito de ressonância entre as vozes, ao trazer à memória um motivo já conhecido e explorado pela outra voz, poderia ser algo que conferiria uma continuidade necessária aos demais motivos melódicos.

\subsection{Stretto}

Desde o séc. XVII, o termo stretto ou stretta tem sido utilizado em música segundo dois significados distintos. O primeiro significado diz respeito à superposição do tema pelas várias vozes de uma fuga, o que geralmente ocorre ao final da peça, e provoca uma intensificação da textura sonora, conduzindo ao clímax anterior ao seu encerramento.

Nesse exemplo de fuga, Bach escreve a entrada consecutiva das diferentes vozes, provocando uma superposição do tema. Em outras obras, que não uma fuga, um stretto significa uma passagem em que o andamento é acelerado, podendo ser, por exemplo, o final de uma ária operística.

Além dessa, temos outrass expressões que podem ser igualmente utilizadas para indicar tais acelerações no andamento, tais como animato, più animato, com anima etc., sendo que Chopin em particular, conforme observado por Poli (2010), chega a utilizar as duas marcações, um stretto seguido 


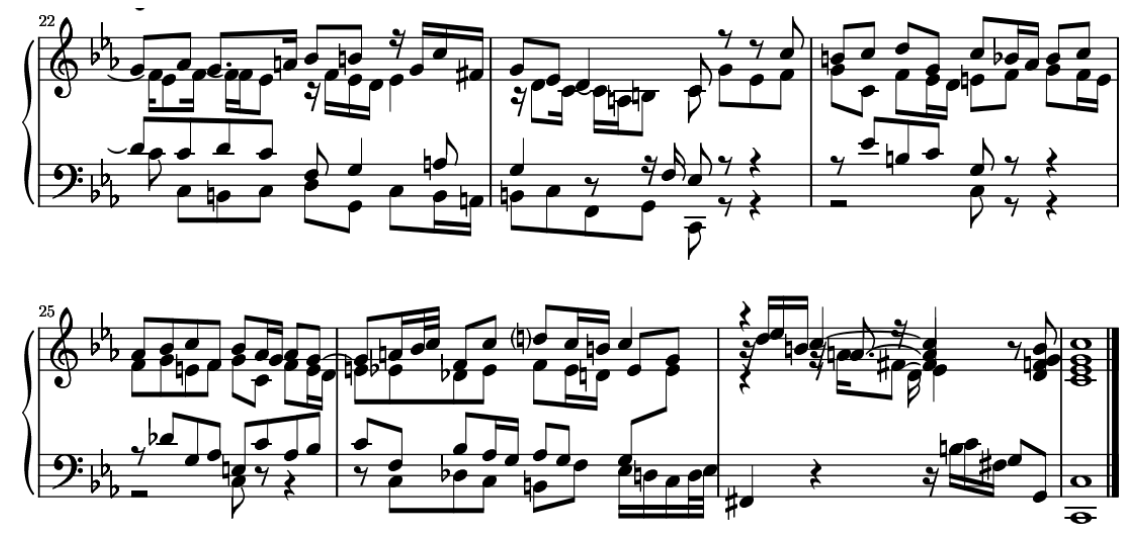

Figura 6.6: J. S. Bach - Prelúdio e Fuga II, v. II Cravo Bem Temperado. Compassos $22-28$.

de um sempre più animato nos compassos 28-35 do Prelúdio op.28 n.16.
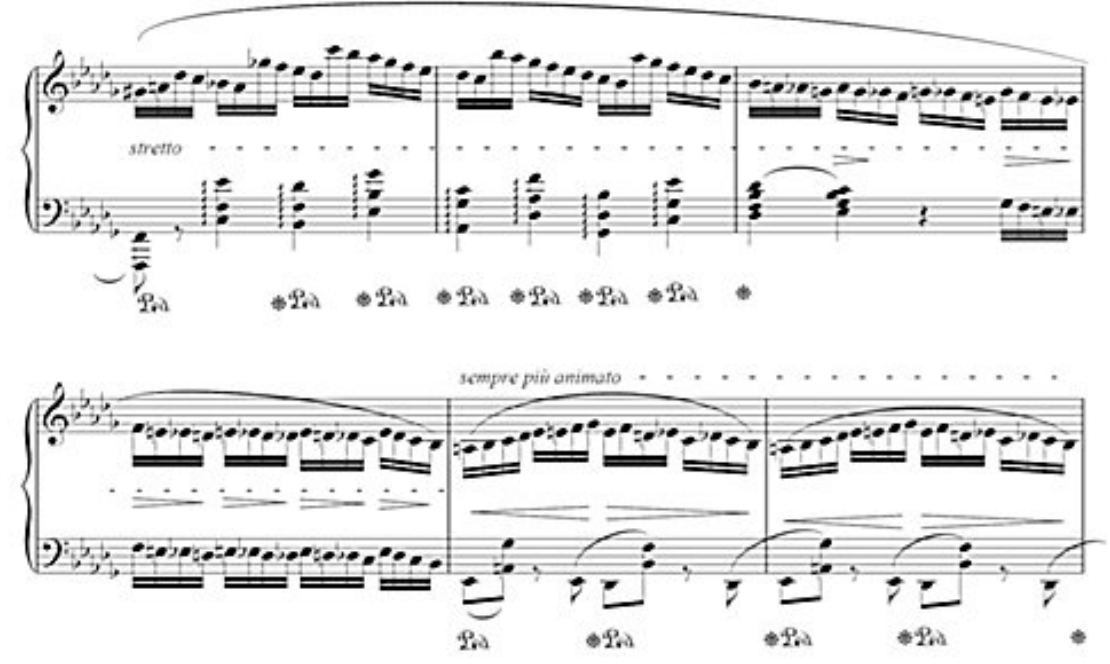

Figura 6.7: Prelúdio op.28 n.16, F. Chopin - compassos 28-35.

Entretanto, há uma diferença na base dessas duas expressões. Enquanto animato recorre à cifra tensiva desta expressão, a qual subentende um caráter mais animado, ou com ânimo, a expressão stretto recorre a uma possibilidade perceptiva causada pela superposição de acontecimentos, ou seja, pela "presentificação do passado e do futuro", o que causa um efeito de aceleração.

Assim, no caso do stretto, temos uma sobremodalização do tempo cronológico pelo tempo mnésico. Enquanto em uma fuga eliminamos o antes e o depois, e presentificamos o passado pela superposição do tema, no stretto com acepção de andamento, remete-se ao mesmo efeito, embora neste caso a 
causa já não seja mais a superposição melódica, mas apenas a sua finalidade temporalizante.

Assim, podemos lançar a hipótese de que tal efeito de fechamento entre as vozes, simulado no stretto da fuga tem na verdade uma intenção de remissividade, característica essa que foi mantida na acepção dada ao termo quando ele se relaciona ao parâmetro andamento.

Podemos observar este efeito nos compassos 43-45 do Noturno op.23 n.2. Neste trecho, o motivo apresentado no compasso 4 aparece em uma sequência acelerada, sobreposta à hemíola no baixo. Neste caso, observamos que tanto Pollini (rv2:17-2:23; ra2:30-2:38) quanto Rubinstein (r3:23-3:32) e Castro (c3:00-3:10), realizam esta aceleração.

Entretanto, em Pollini ra há menos rubato, com uma aceleração contínua, seguida de uma desaceleração que retorna ao tema principal no mesmo andamento de sua primeira aparição. Assim, embora haja uma variação, a aceleração ocorre de modo mais gradativo, o que possibilita um caráter mais contínuo. Já em Pollini rv, além do maior uso do rubato, observamos que o tema é retomado de forma mais acelerada, ressaltando a presença do descontínuo.

No caso de Castro e Rubinstein, percebemos que esta aceleração se inicia alguns compassos antes e ocorre de forma mais gradual, ou com maior preparação, o que também possibilita manter uma maior continuidade no discurso.

Observamos ainda, ao final do Noturno, entre os compassos 69-77, a existência de um trecho típico de um dueto operístico. Segundo nossa análise das gravações, tanto as interpretações de Castro (5:32-5:51) e Rubinstein (5:14-5:40) quanto Pollini (rv3:45-3:58; ra4:11-4:28), privilegiam a independência entre as vozes, evidenciando este fato timbrística e ritmicamente.

Assim, há inicialmente um efeito de desaceleração uma vez que ocorre também uma acentuação no efeito de pergunta e resposta entre as duas vozes, o que possibilita a criação da espera, e a sustentação da continuidade.

Além disso, Pollini (rv e ra) e Castro realizam esse intervalo em an- 
damento similar nas duas sequências de pergunta e resposta, o que significa que, no caso de Castro, houve uma ligeira aceleração dentro desse tempo menos acelerado, se comparado a outras seções da peça, a qual termina de um modo em geral mais acelerado do que seu início. Já em Rubinstein ocorre uma desaceleração na repetição da sequência, correspondente ao smorzando no compasso 73 , tal efeito acentua ainda mais o caráter gradual que esta interpretação apresenta, sendo esta da ordem da continuidade. 


\section{Conclusões}

Ao longo de nossa pesquisa procuramos reunir algumas reflexões que contribuíssem para a compreensão do papel da temporalidade na construção do sentido na música. A partir de nossas análises, pudemos verificar que o tempo é um fator múltiplo que tanto pode ser considerado em relação aos demais parâmetros musicais constituindo, nesse caso, a base pela qual eles se desenvolvem, como em relação a si próprio, possuindo uma forma moldável, passível de sofrer deformidades.

Além disso, levamos em conta o fato de que o tempo musical relacionase com o desenvolvimento do material sonoro e que, por este motivo, torna-se necessário concebê-lo em níveis. Assim, pudemos observar: o seu comportamento em relação a uma linguagem ou sistema composicional, relacionado ao momento de concepção da obra; o modo de notação, por meio da escrita da partitura ou outros sistemas de escrita; o tempo interpretativo, em que o instrumentista irá realizar uma leitura própria da obra, e finalmente o tempo perceptivo do ouvinte.

Todos estes fatores estão presentes na obra musical, que se constitui como um conjunto de possibilidades dentro de um todo passível de ser interpretado, cujas potencialidades serão virtualizadas na partitura. Caberá então ao intérprete atualizar tais valores temporais, ao selecionar aspectos que considere relevantes para a construção de uma leitura própria da obra.

Como vimos, tais leituras não são únicas, e podem variar não somente de um intérprete para outro, mas também entre registros feitos por um mesmo intérprete a depender do instrumento, do local ou das influências sofridas ao longo de um período da vida, as quais podem lhe sugerir uma mudança na concepção original que este tinha da partitura. 
Todas essas leituras, entretanto, remetem a um texto-base, ou a uma obra específica, em um tipo de intertextualidade. Ao mesmo tempo, a atualização dos elementos presentes na partitura, segue princípios relacionados à linguagem à que se refere.

Com a análise do tempo rubato, retirado do op. 15 n.3, percebemos que esse andamento é caracterizado tanto pelas acelerações e desacelerações resultantes de variações rítmicas e durações que as compõem quanto pela base metronômica sobre a qual tais mudanças podem ser realizadas.

Percebemos que um leitor de midi, embora seja capaz de executar uma peça metronomicamente precisa, não é capaz de tocar em tempo giusto, na acepção exato do termo, isto porque o tempo giusto é bem mais um "ajustamento" dos tempos diferentes que compõem o andamento do que a eliminação das demais variáveis temporais.

Procede-se assim a uma espécie de "harmonização temporal". Além disso, a possibilidade de lidar com tal ajustamento demonstra o reconhecimento dos vários tempos que compõem um andamento como, por exemplo, o rubato. Ao mesmo tempo, a existência de tais variações, dosadas segundo as potencialidades de cada obra retoma, segundo nossas análises, seu componente afetivo.

No caso do Noturno op.23 n.2, dentre as gravações selecionadas, percebemos que, com base nos trechos analisados, é possível estabelecer uma gradação tensiva fundada no caráter da interpretação, segundo o modo como ocorrem as variações de andamento e seus efeitos.

Embora fossem necessárias outras análises para sabermos se as inflexões de tempo mais acentuadas em Pollini rv, se devem à presença do público ou ao contexto de recital, percebemos, ao compará-la com Pollini ra, que na realidade um mesmo intérprete pode dosar os efeitos de sentido como tendendo mais ao acontecimento ou ao exercício.

Observamos também que o pulso geral, ou metronômico, de interpretação não é um elemento, por si só, suficiente para definir essa tendência, sendo necessário analisar pontos de inflexão que correspondam às passagens 


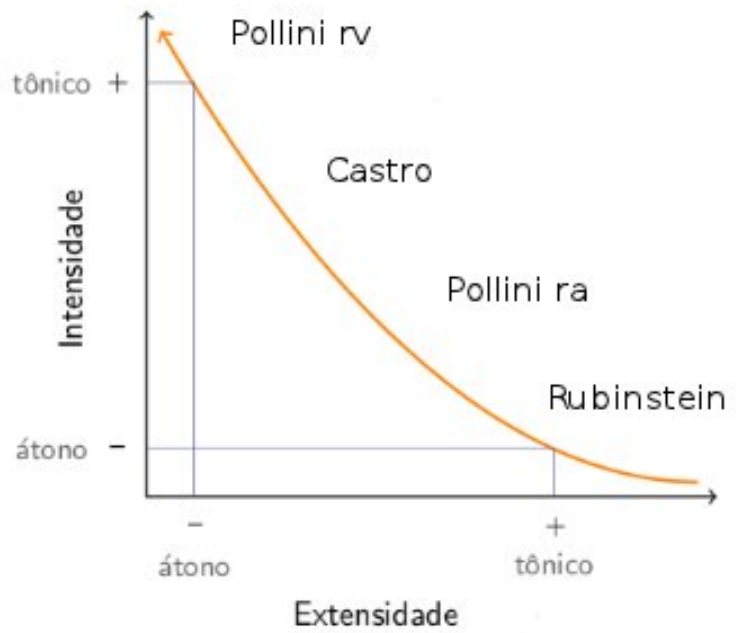

entre trechos mais ou menos acelerados, numa dimensão local.

Assim, concluímos que a análise do andamento segundo suas funções temporais constituintes, torna-se fundamental para compreender as possibilidades de realização da obra e os efeitos de sentido relacionados ao tempo daí decorrentes. 



\section{Referências Bibliográficas}

Adorno, T.W. \& BARras, V. Introduction à la sociologie de la musique: douze conférences théoriques. Contrechamps, 1994.

Bachelard, G. \& Coelho, M. Dialética da duração. Ática, 1994.

Badura-Skoda, E. \& BAdurA-Skoda, P. Interpreting Mozart: the performance of his piano pieces and other compositions. Routledge, 2010.

BARros, D.L.P. "Os sentidos da gestualidade: transposição e representação gestual." CASA-Cadernos de Semiótica Aplicada, vol. 8(2), 5-25, 2010.

Barros, D.L.P. \& Fiorin, J.L. Teoria do discurso: fundamentos semióticos. Atual, 1988.

Barthes, R. L'obvie et l'obtus, vol. 3. Seuil, 1982.

Benveniste, É. "Problemas de lingüística geral i." Maria da Gloria Novak e Luiza Neri, São Paulo: Editora USP, 2005.

Bergson, H. Matéria e memória. São Paulo: Martins Fontes, 1999.

BerIo, L. Remembering the future. Harvard University Press, 2006.

Bertrand, D. Caminhos da semiótica literária. Bauru: EDUSC, 2003.

Boulez, P. Penser la musique aujourd'hui, vol. 13. Denoël, 1963.

- "Entre ordre et chaos." Musique et Perception, Inharmoniques $n^{o}$, vol. $3,122,1988$.

Brelet, G. Le temps musical: essai d'une esthétique nouvelle de la musique, vol. 2. Presses universitaires de France, 1949a.

- Le temps musical: La forme musicale, vol. 2. Presses universitaires de France, $1949 b$.

- L'interprétation créatrice: essai sur l'exécution musicale, vol. 2. Presses universitaires de France, 1951a. 
- L'interprétation créatrice: L'exécution et l'œuvre, vol. 1. Presses universitaires de France, $1951 b$.

Brolezzi, A.C. A Tensão entre o Discreto e o Continuo na História da Matemática e no Ensino de Ciências. Ph.D. thesis, Universidade de São Paulo, 1996.

CARmo JR, J.R. Da voz aos instrumentos musicais: um estudo semiótico. Annablume, 2005.

- Melodia \&S Prosódia: um modelo para a interface música/fala com base na análise comparada do aparelho fonador e dos instrumentos musicais reais e virtuais. Ph.D. thesis, tese de doutorado). São Paulo: FFLCH/USP.[Links], 2007.

- "A enunciação musical em duas interpretações de um prelúdio de chopin." ALFA: Revista de Linguística, vol. 53(2), 479-499, 2009.

Chopin, F., Eigeldinger, J.J. \& Tellefsen, T.D.A. Frédéric Chopin: esquisses pour une méthode de piano. Flammarion-Pere Castor, 1993.

Chouvel, J.M. Analyse musicale: sémiologie et cognition des formes temporelles. L'Harmattan, 2006.

Cohen-Lévinas, D. Le temps de l'écoute: Gérard Grisey, ou la beauté des ombres sonores. Editions L'Harmattan, 2004.

CorBier, C. "Bachelard, bergson, emmanuel. mélodie: rythme et durée." Archives de Philosophie, vol. 2(2), 291-310, 2012.

CRUmP, T. La antropologia de los numeros. Madrid, Alianza Editorial, 1993.

DA Costa, F. A., Newton C. A. \& Doria. Continuous $\&$ Discrete: A Research Program, vol. 12/13. Curitiba: Ed. da UFPR, 1991/2.

Discini, N. Intertextualidade e conto maravilhoso. Editora Humanitas, 2002.

Eisen, C. \& Keefe, S.P. The Cambridge Mozart Encyclopedia. Cambridge University Press, 2006.

EMERY, E. Temps et musique. L'Age d'homme, 1998.

EsCAL, F. "Espaces sociaux, espaces musicaux." Paris: Payot, 1979.

Fiorin, J. L. "Linguagem e interdisciplinaridade." Alea, vol. 10(1), 29-53, junho 2008b. 
Fiorin, J.L. Sendas e veredas da semiótica narrativa e discursiva, vol. 15. DELTA: Documentação de Estudos em Linguística Teórica e Aplicada, 1999.

. "O projeto hjelmsleviano ea semiótica francesa." Galáxia, vol. 3(5), 19-52, 2007.

. Em busca do sentido: estudos discursivos. Contexto, 2008a.

- "Na necessidade da distinção entre texto e discurso." In: BRAIT, Beth \& E Silva, Maria Cecilia Souza (Eds.), Texto ou Discurso?, pp. 145166. Editora Contexto, 2012.

Fontanille, J. \& ZilberberG, C. Tensão e Significação.(tradução de Ivã Carlos Lopes, Luiz Tatit, Waldir Beividas). Humanitas: São Paulo, 2001.

Gerling, F.V. "O tempo rubato na valsa de esquina n. ${ }^{\circ} 2$ de francisco mignone1." CLAVES: Programa de Pós-Graduação em Musica da UFPB, João Pessoa, vol. 5, 7-19, 2008.

Goulemot, J-M. Práticas da leitura, chap. Da leitura como produção de sentidos, pp. 107-116. Chartier, Roger, 2 ed., 2001. Tradução de Cristiane Nascimento.

Greimas, A.J. "Sobre o sentido." Vozes, 1975.

—. Da imperfeição. São Paulo: Hacker Editores, 2002.

Greimas, A.J. \& Courtés, J. Sémiotique. Dictionnaire raisoné de la théorie du langage. Vol. II. São Paulo: Hacker Editores, 1986.

Greimas, A.J. \& Courtés, J. Dicionário de semiótica. São Paulo: Contexto, 2008.

Greimas, A.J. \& Fontanille, J. Semiótica das paixões, vol. 1. São Paulo: Ética, 1993.

Grisey, G. "Tempus ex machina: A composer's reflections on musical time." Contemporary music review, vol. 2(1), 239-275, 1987.

—. Ecrits, ou, L'invention de la musique spectrale. MF éditions, 2008.

Harnoncourt, N. O discurso dos sons. Jorge Zahar Editor Ltda, 2010.

HJelmslev, L.T. Prolegômenos a uma Teoria da Linguagem.(Trad.) José Teixeira Coelho Netto. São Paulo: Perspectiva, 1975. 
Hofstadter, D. Metamagical themas: Questing for the essence of mind and pattern. Basic books, 1996.

HouAiss, A. Dicionário da língua portuguesa. 2009. Rio de Janeiro Instituto Antônio Houaiss, 2009.

Hudson, R. Stolen time: the history of tempo rubato. Clarendon Press, 1997.

IMBERTY, M. Les écritures du temps: sémantique psychologique de la musique. Dunod, 1981.

Jameux, D. "De la sémiologie à la sémantique musicales." Musique en Jeu, vol. $17,1975$.

KRAmeR, J.D. "New temporalities in music." Critical Inquiry, vol. 7(3), 539-556, 1981.

URL http://www.jstor.org/stable/1343117

- The time of music: New meanings, new temporalities, new listening strategies. Schirmer Books New York, 1988.

LÉVY, F. Les écritures du temps (musique, rythme, etc.). Editions L'Harmattan, 2001.

Ligeti, G. "On my etudes for piano." Translated by Sid McLauchlan Sonus, vol. 9, 3-7, 1988.

LOPES, I.C. Morfologias do Tempo: para uma semiótica do que (se) passa. Ph.D. thesis, Universidade de São Paulo, 1998.

Matschulat, J. Gestos musicais no ponteio $n^{o} 49$ de Camargo Guarnieri: análise e comparação de gravações. Master's thesis, Universidade do Rio Grande do Sul, Porto Alegre, 2011.

Menezes, F. A acústica musical em palavras e sons. Atelié Editorial, 2004.

Messiaen, O. Traité de rythme, de couleur, et d'ornithologie:(1949-1992) Tomo I. A. Leduc, 1994.

—. Traité de rythme, de couleur, et d'ornithologie:(1949-1992) Tomo II. A. Leduc, 1995.

- Traité de rythme, de couleur, et d'ornithologie:(1949-1992) Tomo III. A. Leduc, 1996. 
Monteiro, R. N. C. Análise do Discurso Musical: uma abordagem semiótica. 1997. Master's thesis, Dissertação (Mestrado em Semiótica e Linguística Geral)-Universidade de São Paulo, USP. São Paulo, 1997.

- O sentido na música: semiotização de estruturas paradigmáticas e sintagmáticas na geração de sentido musical. Tese de doutorado, Faculdade de Filosofia, Letras e Ciências Humanas, Universidade de São Paulo, 2002.

Mozart, L. A treatise on the fundamental principles of violin playing, vol. 6. Oxford University Press, USA, 1985.

Novaes, G. "Guiomar novaes plays chopin." VOX, 1995. CD 1.

Osmond-Smith, D. Berio. Oxford University Press Oxford, 1991.

PIERre, S. "Traité des objets musicaux." Editions du Seuil Paris France, vol. 1, 700, 1966.

Pietroforte, A.V.S. Retórica e Semiótica. Ph.D. thesis, Tese de doutoramento apresentada ao Programa de Pós-graduação em Lingüística da FFLCH/USP, 2008.

POLI, R. The secret life of the musical notation: Defying Interpretive Traditions. Milwakee, 2010.

Pousseur, H. Apoteose de Rameau e outros ensaios. São Paulo, 2009.

RiBeiro, C.S. Semiótica e tensividade: o fazer missivo, seus desdobramentos teóricos e modos de aplicação. Ph.D. thesis, Universidade de São Paulo, 2011.

Riemann, H. Musikalische Dynamik und Agogik. D. Rahter, 1884.

Roederer, J.G. Introdução à física e psicofísica da música. Edusp, 1998a.

—. Introdução à física e psicofísica da música. Edusp, 1998 .

Rosen, C. Geração Romântica, A. Edusp, 2000.

Sadie, S., Tyrrell, J. \& Levy, M. The new Grove dictionary of music and musicians, vol. 1084. Macmillan New York, 2001.

Saussure, F. Curso de lingüistica geral. Editora Cultrix, 2008.

Schaeffer, P. Traité des objets musicaux: essai interdisciplines. Seuil, 1966. 
Shohet, N., Osostowicz, K., Howat, R. \& Eigeldinger, J.J. Chopin: Pianist and Teacher: as seen by his pupils. Cambridge University Press, 1988.

TARAsti, E. Sémiotique musicale. Presses universitaires de Limoges, 1996.

TAtit, L. Semiótica da canção: melodia e letra. Escuta, 1994.

—. O cancionista: composição de canções no Brasil. Edusp, 1995.

—. "Corpo na semiótica e nas artes." SILVA, IA Corpo e Sentido SP: Ed UNESP, vol. 1(2), 197-210, 1996.

—. Musicando a semiótica: ensaios. Annablume, 1998.

—. "Da tensividade musical à tensividade entoativa." Revista Anpoll, vol. 6(7), 149-173, 1999.

—. Análise semiótica através das letras. Ateliê Editorial, 2001.

—. O século da canção. Ateliê Editorial, 2004.

- Todos entoam: ensaios, conversas e canções. PubliFolha, 2007.

—. "Canção e oscilações tensivas." Estudos semióticos, vol. 6, 14-21, $2010 a$.

—. Semiótica à luz de Guimarães Rosa. Atelie Editorial, $2010 b$.

TAtit, L. \& Lopes, I.C. Elos de melodia e letra: análise semiótica de seis canções. Atelie Editorial, 2008.

UlHÔA, M.T. "A pesquisa e análise da música popular gravada." In: VII CONGRESSO LATINOAMERICANO IASPM (Ed.), Actas del vii congresso latinoamericano iaspm, pp. 1-8. La Habana, 2006.

VALÉRY, P. Variedades. Editora Iluminuras Ltda, 2007.

WisNik, J.M. O som e o sentido: uma outra história das músicas. Editora Companhia das Letras, 1989.

ZilberberG, C. L'Essor du poème: Information rythmique. Phoriques, 1985.

—. "Relativité du rythme." Protée Théories et pratiques sémiotiques, vol. 18, 37-46, 1990. 
__. "Presénce de wolfflin." Nouveaux Actes Sémiotiques, vol. 23-24, 1992.

- "Signification du rythme et rythme de la signification." Degrés, vol. 24(87), a1-a25, 1996.

_. "Remarques sur lassiette tensive du rythme.", 2001.

URL http://www. claudezilberberg. net/download/downset.htm

—. "Précis de grammaire tensive." Tangence, vol. 70, 111-143, 2002.

—. Razão e poética do sentido. EdUSP, 2006.

—. Elementos de Semiótica Tensiva. Atelie Editorial, 2011.

Softwares:

Audacity <http://audacity.sourceforge.net $>$, acesso em 06/02/2012.

Sonic Visualizer <http://www.sonicvisualiser.org $>$, acesso em 06/02/2012.

\section{Sites consultados:}

http://www.cfeo.org.uk

http://chopin.lib.uchicago.edu/ 


\section{APÊNDICE}

\section{Transcrição da entrevista com Greimas}

\section{Parte 1}

\section{Le problème du timbre}

Q. C'est l'usage, dont vous parlez, [qui] relève peut-être du problème du timbre. Je pense notamment à votre idée d'analyser le timbre musical en terme d'aspectualité. Est-ce qu'il y a là aussi la possibilité d'une connexion avec le travail fait en phonologie et en phonétique?

R. Justement, la phonologie et la phonétique acoustique actuelle a fait des progrès considérables dans ce domaine. Alors, on peut se demander si, par analogie, ce modèle ne peut pas être appliqué à l'analyse musicale.

Là, il faudrait distinguer deux choses : d'un côté, on pense souvent aux formes musicales comme une syntaxe, c'est-à-dire, qu'il y a une linéarité temporelle de la musique et c'est sur cette ligne qu'on écrit les formes et leur évolution, leur allitération, leur récursivité et tout cela. Alors, c'est là que se situe le problème de l'aspect. C'est plus que caractéristique que, par exemple, pour la musique classique, l'aspectualitée n'est pas marquée par la notation symbolique mais, par des mots italiens. Alors, si on prenait ces mots italiens, si on essayait d'en faire une classification morphologique, on verrait, en effet, le rôle que joue l'aspectualité, parce qu'il s'agit là du discours. Ça c'est une chose.

Maintenant, en ce qui concerne le timbre je verrais cela un peu autre- 
ment, je verrais ça comme une sorte de paradigmatique, c'est-à-dire, ce qui se passe après, quand les sons d'origines diverses, provenant d'instruments différents, sont articulés en même temps [et] produisant ce syncrétisme sonore. Ça c'est, tout à fait, penser à des phonèmes.

Ce qui rend difficile l'analyse musicale c'est qu'elle n'est pas encore arrivée à formuler cette taxinomie des sons. Le problème est simple, voyez pourquoi nous sommes coincés [a le faire], quand il s'agit d'analyser, par exemple, la communication, qui n'est plus sur le plan du sonore, mais sur le plan olfactif.

Les sémiotiques des parfums seraient possibles seulement quand dénommonsnous ce qui sens bon, on dit la rose on dit l'oeillet etc. C'est quoi de la clarinette, au violon c'est-à-dire les sons sont désignés par mode de fabrication et non pour ce qu'ils sont. Le parfum, c'est un composé complexe de choses et la communication parfumée se situe dans un autre plan. Ce que je veux dire, c'est qu'il ne pas du tout [sûr] que ça soit tel au tel forme d'oeillet ou de rose.

Alors, avec la musique aussi, il faudrait élaborer une sorte de phonologie des sons très distinctifs et c'est le timbre qui, pour moi, est la clé de l'affaire. Je ne sais pas si c'est possible, mais je crois qu'[il faut le faire] pour situer les universaux de la musique et non pas seulement rester au niveau du discours musical.

\section{Le symbolisme dans la musique}

Q. Claude Lèvi-Strauss, que vous avez cité et avec lequel vous avez beaucoup travaillé, ainsi que Hjelmslev, tout deux faisant partie de l'episthéme profonde de votre théorie, ont parlé, même si d'une manière un peu différente, d'une part de la fonction symbolique de la musique et du fait que la musique s'articule à travers une structure dite symbolique.

Qu'elle est, à votre avis, le rapport entre la musique, au sens général du mot et le problème vaste du symbole? 
R. Là vous placez des pièges... évidemment le problème du symbolisme est obscurci, occulté justement par les différents usages qu'on fait de ce mot. Très souvent, les gens ne se comprennent pas, ne s'entendent pas, parce qu'ils ne parlent pas des mêmes choses. Qu'est-ce qui est symbolique? Parce que les considérations des philosophes du langage tel que Cassirer, par exemple, emploie le terme symbolique pour dire que la langue naturelle, la langue que nous parlons, est un système symbolique. À leur sens, il y a l'algèbre, [qui] c'est un système symbolique, [mais] vous voyez qu'[il y a] une différence énorme. Si vous vous référez à la psychanalyse c'est encore autre chose, alors évidemment on ne sait pas, dans chaque cas concret, de quoi les gens parlent.

Je pense, donc, qu'il faut tenir compte des possibilités du discours musical. D'une part, ce discours est, évidemment, la manifestation du procès linguistique, car il est incontestable que cela a un sens et qu'il y a une articulation du signifiant. Quelles sont les modes d'articulation ? Ça c'est une question subsidiaire, déjà. Alors, on peut considérer la musique comme une articulation dans le discours de plusieurs possibilités. Ça pourrait être comparé à quelque chose comme une langue naturelle, mais aussi comme un système ou l'investissement des systèmes semi-symboliques par certains endroits comme du symbolisme, disons, algébrique presque a d'autres endroits, puisque le discours est la réalisation de tous les possibles [les universaux] musicaux des formes musicales qui font parties du reservoir dont les musiciens se servent pour parler musicalement.

Cette distinction autour du discours et des universaux musicaux est capital pour comprendre ce qui se passe. Je ne fait, d'ailleurs, qu'appliquer les principes théoriques qu'on fait [auprès] de la sémiotique en proposant de réfléchir. Ça peut donner quelque chose, ce type de modèle de réflexion sur la musique.

\section{Définition du terme symbolisme}


Q. Est-ce que vous pourriez préciser ce sens très spécifique et technique que le sémioticien utilise du mot symbole et que pourrait s'appliquer à la musique $?$

R. Oui, vous savez, ce sens particulier n'est pas propre à la sémiotique. La logique et la mathématique emploient dans le même sens le mot symbole. C'est le caractère arbitraire, c'est la balance qui symbolise la justice. De manière arbitraire, sans qu'il y ait une relation entre [la] balance et la justice. Historiquement, évidemment, on peut trouver des explications mais, autrement il y a quelque chose qui arrive et qui se produit sans relation.

Je pense du discours musical qui serait coulant, tensif et puis, d'un seul coup, sur le grand tambour, on donne un coup sans une relation logique avec le discours lui-même, alors dans ce cas c'est, pour moi, l'emploi du symbolisme parce que ça peut signifier l'éclatement de quelque chose, frontière ou autre chose... tandis que le sémi-symbolique serait donc la prise en charge d'une petite structure binaire, ternaire, quaternaire, où les sens sont disposés de telle manière que ça provoque des oppositions de sens, c'est-à-dire, que là sur le plan pathémique, sur le plan des passions on sent l'inversion des passions ou le passage de l'une et de l'autre suivant, mais dans ce petit cercle ils sont déterminés par l'ensemble de l'oeuvre, [laquelle] peut se développer autrement. J'espère que je n'ai pas dit des bêtises.

\section{Le problème du pathémique}

Q. Justement, vous introduisez là le problème du pathémique, le problème des passions que l'auditeur ressent dans son écoute et que le compositeur, pourquoi pas, éprouve dans la manipulation du son.

Je crois que là c'est un problème capitale qui a été plusieurs fois signalé par les musicologues et les esthéticiens et au sujet des passions vous avez élaboré une théorie que se rattache à théorie générale sémiotique et qui a 
essayé de décrire et expliquer une sorte de syntaxe de la passion.

Est-ce que cet effort théorique peut trouver une application en sémiotique de la musique?

R. Je crois que oui. C'est-à-dire que dans le langage commun, quand en parle de la musique on dit c'est le langage des sentiments, alors ça faire un peu..., c'est comme si enfin la musique, c'est sentimentale... alors que si on remet les choses à leur place, si on traite les passions, je dis passions justement c'est ce terme que j'ai choisi, mais quand je ne parle pas de sentiments, d'émotion, c'est un vieux mot des philosophes du 17e siècle pour dire enfin tout ce qui concerne en fait notre affectivité notre thymisme.

Alors, la passion dans ce cas devient en effet et c'est pour ça que nous l'avons baptisé sur le conseil de Paolo Fabri, [comme] pathémique. Le niveau pathémique, d'ailleurs ça vient de Spinoza. Alors, pour comprendre qu'il y a tout un niveau du discours presque indépendant du reste du pragmatique, du cognitive...quelque chose où les passions se déroulent et que la passion ce n'est pas du sentiment... c'est quelque chose...c'est la tensivité de notre être qui bouge, qui est tendu et détendu... c'est en ce niveau qu'en peut chercher à comprendre le phénomène musicale.

La théorie des passions a fait chez les sémioticiens tel progrès que, certains proposent même de [les] considérer comme une dimension autonome, disons, de la narrativité, de la communication...en plus je dirais qu'on ne peut pas comprendre ce thymique, ou pathémique comme quelque chose uniquement affective. Il y a beaucoup de cognitif dans le passionnel et beaucoup de passion dans le cognitif. Finalement, le signifié musical est à la fois pathémico-cognitif et que c'est une chose que l'on peut et doit prendre très au sérieux...

En plus, il y a le caractère sonore du langage musical et ce la fait qu'il soit plus profond que le signifiant visuel, par exemple, ou que le signifiant articulé des langues naturelles, ce qui fait [possible] qu'on peut peut-être même oser une certaine distinction entre les passions de l'âme et les passions 
du corps... et que la musique, peut-être, touche cet aspect des passions du corps, comme disait Descartes. L'emprise est beaucoup plus forte, je ne sais pas comment formuler ça. C'est intuitif. C'est dans cette direction que je chercherais à comprendre un peu le signifié musical qui me semble être quelque chose digne d'intérêt et qui promet toutes les difficultés du monde, mais pourrait évidemment enrichir considérablement la théorie sémiotique.

(Espécie de corte, Greimas continua alguma fala anterior)

...[une chose] qui était très vivante à la première moitié de ce siècle, a partir de 1900, c'est ce qu'on appelait la correspondance des arts...on se demandait comment peut-on établir des comparaisons [et] en quoi...est-ce qu'il y a une structure musicale qui serait comparable, qui serait traduisible en visualité?

Par exemple, la musique moderne ne trouve plus de notation adéquate et la notation devient de la peinture également. Alors, la réponse de la sémiotique pourrait être un peu en dehors de ce problème de surface... la réponse est hjelmslevienne : le signifiant est articulé par des formes qui sont comparables aux formes par lesquelles s'articulent les signifiés et finalement ce sont des formes abstraites d'où le rapprochement médiévale avec les mathématiques... c'est-à-dire que, il est possible, en dernière analyse, de réduire la forme sonore à des formes abstraites articulées...alors de même que la peinture [laquelle] par l'analyse, est productible comme un ensemble d'abstractions configuratives...[et] à ce niveau seulement qu'on pourraiy parler de la correspondance. On verrait que tel discours musical est comparable à tel discours picturale. On verrait ensuite [que] la spécificité de chacun des languages est depouis longtemps commun. [Cette question] me parait une tentation enfin très interessante, [mais] peut-être nous ne sommes pas encore là.

\section{La connaissance des formes temporelles}


J'ai parlé du manque que la sémiotique éprouve et qui pourrait être seulement remplie par la contribution de la sémiotique musicale, c'est le peu de connaissance que nous avons des formes temporelles [car] la musique se développe dans le temps. Alors, en ce qui concerne les formes spatiales je peux penser à l'analyse de la peinture, nous disposons des formes saisissables donc articulables et réductibles à des formes géométriques simples etc. [comme] une sorte de topologie.

Alors, [une fois] que le temps c'est la spécialité en quelque sorte de la musique et de ces formes, nous en savons très peu de choses [sur ce plan], donc il faudrait qu'il ait cet apport de la musicologie pour qu'on puisse comprendre ensuite [si] les formes temporelles et spatiales sont réductibles à un dénominateur commun $[\ldots]$

C'est dans ce sens probablement qu'il me parait qu'il faut musicaliser la sémiotique... je suis persuadé que [d'autre forme] l'horizon sémiotique [ni] se transformerait ni changerait et prendrait du poids et de l'ampleur... et [qu'il faut poser] ce genre d'analyse maintenant à des résultat concrets parce qu'on a trop facilement, d'après moi, la tendance de se moquer des gens qui n'écoutent Bach par exemple, disent qui c'est une architecture comme l'imaginaire produit des formes architecturales...

Je crois qu'il y a quelque chose de plus, qu'il y a une sorte de correspondance peut-être entre la spatialité et la sonorité et que c'est là qu'il y a les liens communs et que, finalement, l'enjeux c'est la connaissance de l'homme du sens du monde pour l'homme. Je pense que c'est quelque chose, c'est ne pas de plaisanterie et que la musique peut-être une chose sérieuse.

\section{Parte 2}

\section{Fala de Greimas}

...Du discours musical que ce n'est pas que la fusion totale, ça serait donc l'éclatement, l'explosion du monde! Il en résulte qu'il y a des temps forts 
après des fusions et puis après des relachements, des détentions qui se produisent. On peut prendre l'exemple littéraire connue de tous, [par exemple], une pièce de Marie vous voyez qui c'est de Marie Godard, une popote... [quelqu'un qui] plaisante c'est tout un processus du comique léger et puis d'un seul coups [on identifie] ce qui se passe ${ }^{1}$, c'est celui qui ouvre la bouche et dis — "Je vois claire dans mon coeur!"2 - et ça y est, Marivaux est là...alors c'est comme ça que je dirais, enfin, qu'un discours musical peut être lu, c'est une des façons... il y a une sorte de sommaire ou vraiment il y a une prise charnelle entre le signifiant et le signifié [qui] est concilié avec le monde.

\section{Le discours et la structure musicale}

Q. Est-ce que cette relation que vous posez entre l'homme et le monde ${ }^{3}$, entre le son et le sens et le signifié et le signifiant relève d'une certaine manière, comme vous l'avez écrit, d'une sorte d'euphorie pure... et, est-ce que cette conjonction a un peu à faire à ce que Herman Parret appelle la tensivité du plaisir de l'écoute musicale?

R. Je ne sais pas si c'est par là qu'il faudrait poser la question, je veux dire qu'il est évident que c'est un art temporel et nous sommes incapables de saisir le temps autrement que pas des aspects du temps, par la durée, la durativité, l'attaque, l'incoativité et l'évanescence...etc. ce sont-là les caractéristiques pour moi du discours musical.

Dans le sens où l'entend la production particulière de telle ou telle oeuvre, alors que les structures musicales, sont un autre chose. C'est le sujet, le compositeur qui fait le choix des possibilités musicales, des systèmes et des organisations musicales pour parler son propre discours et tout

\footnotetext{
${ }^{1}$ Podemos perceber aqui referência direta à Commedia dell'arte, forma teatral baseada no improviso e que contava entretanto com personagens fixos, com modo de expressão, personalidade e vestimenta característicos, estereoripados. Tal gênero teatral, surgido durante o XV na Itália, influenciou enormemente Marie Godard e Marivaux, escritores franceses do séc XVIII aqui citados por Greimas.

${ }^{2}$ Frase retirada da peça Le Jeu de l'amour et du hasard (act 2, scene 12), proferida pela personagem Silvia.

${ }^{3}$ Referência à questão anterior, a qual retoma aspectos sociológicos na obra de Marivaux.
} 
l'aspectualisation temporelle intervient là. Alors, évidemment si vous voulez analyser à partir du discours d'une oeuvre particulière, vous rencontrez d'abord la tensivité et cette aspectualisation, c'est-à-dire que ça parait comme fondamentale.

La difficulté, donc, à la musique c'est qu'il faut prévoir les choses qui sont antérieures logiquement à la construction des différents discours, parce que dans les discours il y a de tout. On n'aura pas distingué les différents niveaux de profondeur, la sémiotique musicale risque de rester actuellement un analyse textuelle des textes, [il faut] préciser que [dans] tout ce mélange le discours réalise absolument toutes les possibilités. Alors il n'y a pas des moyens d'analyse rigoureux.

\section{Niveaux de pertinence dans la musique}

Q. Cette exigence que vous soulignez très précisément d'introduire des niveaux de profondeur superposés, des niveaux de pertinence pour l'analyse du discours musical. Est-ce que pourrait être comparé à l'analyse de la narrativité littéraire?

R. Là aussi je crois qu'il faut prendre d'abord toutes les précautions. C'est-àdire, ce qui se passe c'est qu'il y a certains genres musicaux qui se prêtent à la narrativité. Qu'est-ce que ça veut dire? Pour moi c'est le fait que le discours particulier qui a un genre musical peut reproduire le schema narratif presque dans son entier. Du même coup on confond donc dans un seul discours les structures narratives et le discours musical. Alors là, il y a des exemples que j'ai connu de l'analyse, par exemple, que Nicolas Arrivé a fait dans mon séminaire [il y a] longtemps, [où] il analyse des fugues. Ensuite d'autre exemple qu'en peut s'en servir c'est l'analyse de Lévi-Strauss du boléro de Ravel et [de] Tarasti avec le genre de discours mythique où enfin le discours se boucle lui-même.

Ça rassemble beaucoup, par certain côté, à des contes merveilleux, par 
exemple, où [on] a des mythes qui ont une structure achevée.

Seulement c'est n'est qu'un des genres possibles, assez rare je crois, de la musique moderne. Ce que je suggère c'est d'analyser ces choses séparément. Il y a de la narrativité du discours mais c'est l'auteur qui y met certaines doses à certains endroits et réorganise, anachronise tout et ceci nous oblige à procéder à deux analyses distinctes, à ne pas confondre. Alors, Il y a le bon usage de la narrativité dans le discours musical ou le mauvais usage, bien sûr si vous voulez, ça c'est autre chose. 